\title{
A new genus and three new species of mangrove slugs from the Indo-West Pacific (Mollusca: Gastropoda: Euthyneura: Onchidiidae)
}

\author{
Benoît DAYRAT 1,*, Tricia C. GOULDING ${ }^{2}$, Munawar KHALIL ${ }^{3}$, Deepak APTE ${ }^{4}$, \\ Adam J. BOURKE ${ }^{5}$, Joseph COMENDADOR ${ }^{6} \&$ Shau Hwai TAN $^{7}$ \\ ${ }^{1,2}$ Department of Biology, Pennsylvania State University, University Park, PA 16802, USA. \\ ${ }^{2}$ Current address: Malacology, Bernice Pauahi Bishop Museum, \\ 1525 Bernice St., Honolulu, HI 96817, USA. \\ ${ }^{3}$ Department of Marine Science, Universitas Malikussaleh, Reuleut Main Campus, \\ Kecamatan Muara Batu, North Aceh, Aceh, 24355, Indonesia. \\ ${ }^{4}$ Bombay Natural History Society, Mumbai, Hornbill House, Opp. Lion Gate, \\ Shaheed Bhagat Singh Road, Mumbai 400 001, Maharashtra, India. \\ ${ }^{5}$ EcoScience NT, 29 Ostermann St., Coconut Grove, NT 0810, Australia. \\ ${ }^{6}$ National Museum of the Philippines, Taft Ave., Ermita, Manila, 1000 Metro Manila, Philippines. \\ ${ }^{7}$ School of Biological Sciences, Universiti Sains Malaysia, 11800 Minden Penang, Malaysia. \\ ${ }^{7}$ Centre for Marine and Coastal Studies, Universiti Sains Malaysia, 11800 Minden Penang, Malaysia. \\ *Corresponding author: bad25@psu.edu, bdayrat@gmail.com \\ ${ }^{2}$ Email: tc.goulding@gmail.com \\ ${ }^{3}$ Email: khalil@unimal.ac.id \\ ${ }^{4}$ Email: spiderconch@gmail.com \\ ${ }^{5}$ Email: ecoscience2@bigpond.com \\ ${ }^{6}$ Email: joseph.comendador@gmail.com \\ 7Email: aileen@usm.my

\footnotetext{
${ }^{1}$ urn:Isid:zoobank.org:author:192B0AF4-A4B0-4129-8422-DEF8D0FB4A45

${ }^{2}$ urn:1sid:zoobank.org:author:6009A165-E73E-4124-96C6-C143FC51B18F

${ }^{3}$ urn:lsid:zoobank.org:author:6D38234D-0DE1-4CDE-9F7E-603070C9B27D

${ }^{4}$ urn:lsid:zoobank.org:author:5335B286-7B3A-440A-B16B-FBABCD90274B

${ }^{5}$ urn:lsid:zoobank.org:author:AAF38199-57BF-4E7E-A888-468A9B01720C

${ }^{6}$ urn:1sid:zoobank.org:author:0EAAEF74-7E54-47BA-9A3A-D3A4ED40AD85

${ }^{7}$ urn:Isid:zoobank.org:author:6E9B8F28-EFCC-42F1-A7C4-3957C92995AA
}

\begin{abstract}
Mangroves of the Indo-West Pacific have remained poorly explored, so even the diversity of the onchidiid slugs, which are some of the most abundant animals in mangroves of the Indo-West Pacific, is not well known. Thanks to several years spent exploring mangroves in the Indo-West Pacific (more than 260 stations), especially in South-East Asia, the diversity of mangrove gastropods can now be addressed through revisions following an integrative taxonomy approach (nomenclature, field observations, comparative anatomy and DNA sequences). A new genus of onchidiid slugs is described, Paromoionchis Dayrat \& Goulding gen. nov., which includes five species, three of which are new: Paromoionchis boholensis Dayrat \& Goulding gen. et sp. nov., P. daemelii (Semper, 1880) com. nov.,
\end{abstract}


P. goslineri Dayrat \& Goulding gen. et sp. nov., P. penangensis Dayrat \& Goulding gen. et sp. nov. and P. tumidus (Semper, 1880) comb. nov. Paromoionchis gen. nov. is distributed from western India to the subtropical waters of Japan $\left(33^{\circ} \mathrm{N}\right)$ and southeastern Australia $\left(33^{\circ} \mathrm{S}\right)$. The creation of new taxon names is supported by rigorous nomenclature: the types of all existing species names in the family were examined, the original descriptions carefully studied and nomenclatural issues addressed. The diversity and biogeography of this new genus is discussed in a broader context.

Keywords. Biodiversity, Coral Triangle, integrative taxonomy, revisionary systematics, South-East Asia.

Dayrat B., Goulding T.C., Khalil M., Apte D., Bourke A.J., Comendador J. \& Tan S.H. 2019. A new genus and three new species of mangrove slugs from the Indo-West Pacific (Mollusca: Gastropoda: Euthyneura: Onchidiidae). European Journal of Taxonomy 500: 1-77. https://doi.org/10.5852/ejt.2019.500

\section{Introduction}

Onchidiid slugs are closely related to land snails and slugs, but they are truly marine because their larvae develop in seawater and because their adult life takes place in the intertidal (Dayrat et al. 2011a). Exceptionally, a few species are terrestrial and live in high-elevation rainforests (Dayrat 2010). Onchidiids are distributed worldwide, except at the poles. One subclade - traditionally referred to as Onchidium Buchannan, 1800 - has diversified in the Indo-West Pacific, especially South-East Asia. Another subclade - traditionally referred to as Onchidella J.E. Gray, 1850 - has diversified outside the Indo-West Pacific, especially in temperate waters. These subclades overlap geographically at the borders between the subtropical Indo-West Pacific and temperate waters (i.e., southeastern Australia, South Africa and Japan).

Even though onchidiids are widespread and common, their biodiversity has remained very poorly understood (Dayrat 2009). Some of the obvious reasons explaining this situation are that 1) onchidiid taxonomy has not been revised for more than 80 years, 2) new species names were often being created with little to no consideration for existing names, 3 ) internal characters (which are key at both specific and generic levels) were often ignored and 4) species were described based on preserved specimens without any field observations on live animals. As a result, 150 species names exist in the literature, but, until now, no onchidiid species could be properly identified, which is especially true in the Indo-West Pacific, where onchidiids are common and diverse (with dozens of species). Species relationships at the generic level also need to be completely re-evaluated. For instance, it was recently demonstrated that the genus name Onchidium actually applies to a small clade including only three species (Dayrat et al. 2016).

The Dayrat lab is in the process of revising the taxonomy of the entire family, using an integrative approach (Dayrat 2005). Our efforts have focused on collecting fresh material, getting new morphological and molecular data, addressing the nomenclatural status of every single existing species- and genusgroup name by re-examining the totality of the types available (many museum collections were visited specifically for that purpose) and critically going through the entire primary and secondary literature. Over the past few years, we have spent considerable time collecting fresh material, most especially in the mangroves of South-East Asia and Australia, where onchidiids are often the most abundant animals. We have collected thousands of specimens from more than 300 stations worldwide (as of August 2018), including many original type localities. This exploration has allowed us to gather invaluable information on the natural history and color variation of live onchidiids. Those new collections were used to build a large integrative data set which now includes approximately 80 species and 10 clades of generic level. Each taxon is strongly supported by both morphological and molecular data. 
In order to finally establish some order in the taxonomy of the Onchidiidae, we are comprehensively revising every genus, focusing on one genus at a time. Several genera and many species in our data set are new to science. Also, species with existing names are often known only from the original description and need to be fully re-described. Six revisions have already been published on Onchidium (Dayrat et al. 2016), Onchidina Semper, 1882 (Dayrat \& Goulding 2017), Melayonchis Dayrat \& Goulding, 2017 (Dayrat et al. 2017), Alionchis Goulding \& Dayrat, 2018 (Goulding et al. 2018a), Peronina Plate, 1893 (Goulding et al. 2018b) and Wallaconchis Goulding \& Dayrat, 2018 (Goulding et al. 2018c).

The purpose of the present contribution is to describe a new genus, Paromoionchis Dayrat \& Goulding gen. nov., which includes five species. Two of those species were known only from the original description and are re-described here for the first time with many new geographical records. The three other species are new to science. The nomenclatural status of several other existing species names is addressed. Three species names are shown to be junior synonyms of a Paromoionchis gen. nov. species name. Five species names are regarded as names of doubtful application (nomina dubia) for a variety of reasons.

\section{Material and methods}

\section{Field collecting and sampling}

Only five specimens (out of 156) used in this study were not collected by us: two Queensland specimens of $P$. daemelii (Semper, 1880) and one Queensland specimen of $P$. tumidus (Semper, 1880) were found in the collections of the Australian Museum, Sydney; two specimens of $P$. tumidus collected during an expedition led by Philippe Bouchet to Madang, Papua New Guinea, were obtained from the Muséum national d'Histoire naturelle. All other 151 specimens examined here were collected by us in the context of an exploration of mangrove snails and slugs across the Indo-West Pacific, which provided fresh material for DNA sequencing and invaluable natural history observations. Collecting parties were led by Benoît Dayrat in the Andaman Islands (India), Brunei Darussalam, Malaysia, New South Wales and Northern Territory (Australia) and the Philippines, by Tricia Goulding in eastern and western India, Queensland (Australia) and Vietnam, by Rebecca Cumming in Japan and by Munawar Khalil in Indonesia. We were often accompanied by local guides (villagers or fishermen). Sites were accessed by car or by boat. Each site was explored for an average of two hours, but the exact time spent at each site also depended on the time of the low tide, the weather, etc. At each site, photographs were taken to document the kind of mangrove being visited as well as the diverse microhabitats where specimens were collected.

In the field, specimens were individually numbered and photographed in their habitat (it is very important to take photographs before animals are touched because they retract when disturbed and do not relax again for a long time). Importantly, a piece of tissue was cut from all specimens individually numbered (for DNA extraction) and the rest of each specimen was relaxed and fixed for comparative anatomy.

In the field, detailed notes were written, commenting on whether specimens could be part of the same species or not. We tried our best to sample as much diversity as possible at each site. In addition to numbering the specimens that looked different individually, we also numbered many specimens that looked similar individually, so that we could test for the presence of cryptic diversity. This practice ended up being absolutely key to discovering all the species described here and documenting their natural history, because they are externally cryptic, which is something we did not know when we first started. Per species, the numbers of specimens included in the present study are: 33 (P. boholensis gen. et sp. nov.), 11 (P. daemelii), 22 (P. penangensis gen. et sp. nov.), 21 (P. goslineri gen. et sp. nov.) and 69 (P. tumidus). Finally, only three COI sequences from mainland China were found in GenBank for P. tumidus (misidentified as Paraoncidium reevesii (J.E. Gray, 1850)) and were added to our molecular data set. 


\section{Type material, museum vouchers and collections}

Sound taxonomy is impossible without re-examining all types available. So, the types of existing onchidiid species names were all borrowed for re-examination. Many museum collections were visited in person (by the first author) in order to track types, because types are actually often mixed in with the general collections. Original descriptions surely are important (especially when the type material is lost), but re-examining all types is absolutely indispensable in order to address the status of all existing names and determine whether species are new or not. Most species described in the past were based on syntypes. We designate a few lectotypes here in order to clarify some nomenclatural situations.

All specimens were deposited as vouchers in institutions of the country where they were collected. Acronyms of collections are:

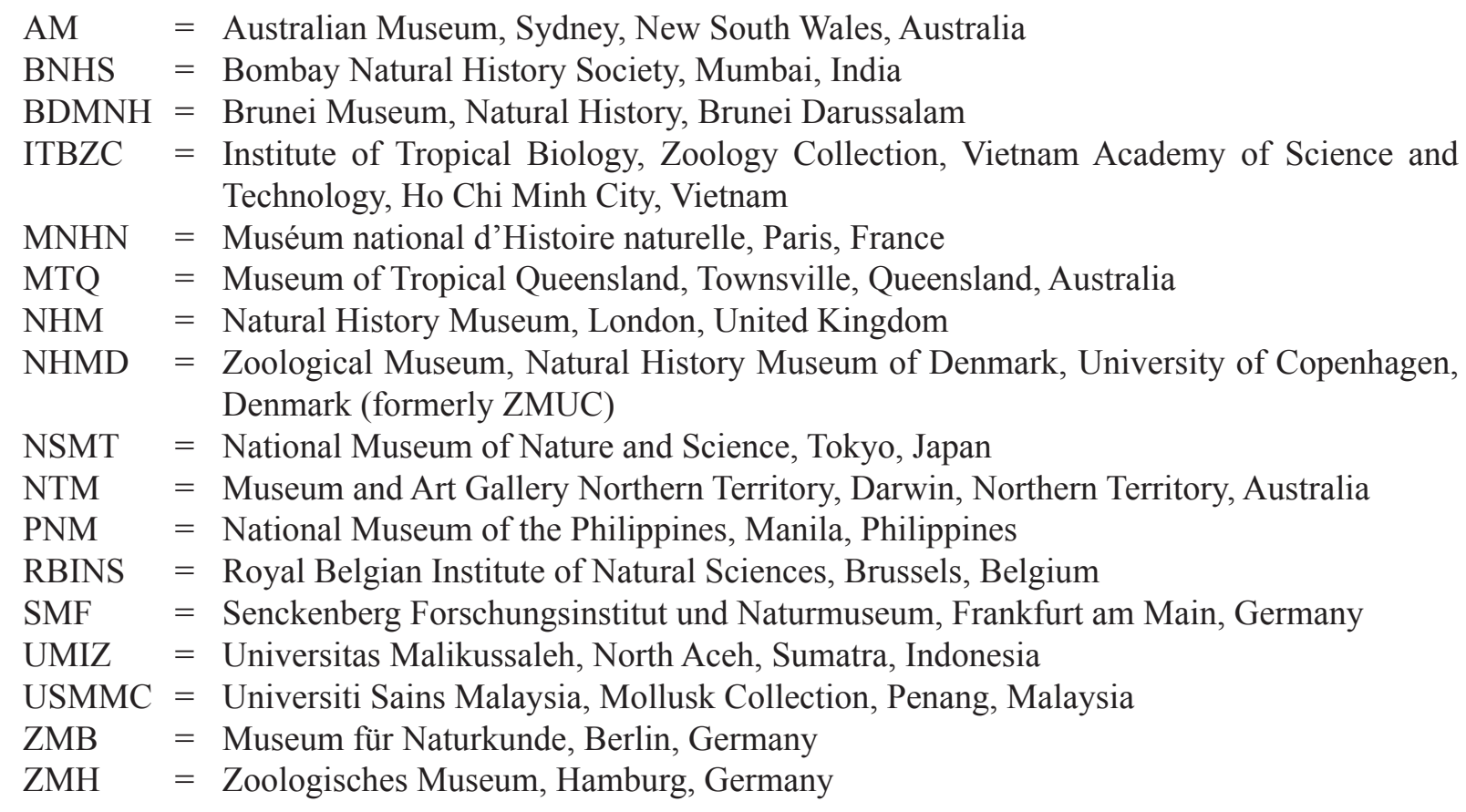

\section{Animal preparation and anatomical description}

All anatomical observations were made under a dissecting microscope and drawn with a camera lucida. In addition, organs were prepared for scanning electron microscopy (SEM). Radulae were cleaned in $10 \% \mathrm{NaOH}$ for a week, rinsed in distilled water for at least a week, briefly cleaned in an ultrasonic water bath (less than a minute), sputter-coated with gold-palladium and examined by SEM. Soft parts (penis and penial hooks) were dehydrated in ethanol and critical point dried before coating. When a lot included several specimens, all pieces of the dissected specimens were carefully numbered, both inside the jar and on the SEM stubs. Individualized numbers (in square brackets) and measurements (length/ width) are provided for each specimen in the 'Material examined' sections (all specimens included in the material examined sections are included in the molecular data set).

The anatomy of $P$. tumidus, the type species, is fully detailed. The written description of the many anatomical features that are virtually identical between species (nervous system, heart, etc.) is given only for the type species to avoid repetition. Thus, any feature that is only mentioned for P. tumidus is identical in the four other species. The color of live animals is described in detail for all species in order to demonstrate the overlapping individual variation between species. As expected, differences between species are mostly found in the male copulatory apparatus, which is described and illustrated in detail 
DAYRAT B. et al., A new genus of mangrove onchidiid slugs

for each species. Special attention has been paid to illustrating the holotype of each of the three new species. For instance, the line drawings (digestive system, female reproductive system, male copulatory apparatus) systematically feature the holotype, the color plate with live animals always includes a photograph of the holotype and the plate illustrating the species' habitat also includes a photograph from the type locality.

\section{DNA extraction and PCR amplification}

DNA was extracted using the phenol-chloroform extraction protocol with cetyltrimethyl-ammonium bromide (CTAB). Portions of three mitochondrial genes (COI, 16S, 12S) were amplified using the following universal primers (all 5'-3'): COIF GGT CAA CAA ATC ATA AAG ATA TTG G and COIR TAA ACT TCA GGG TGA CCA AAR AAY CA (Folmer et al. 1994) for COI; 16Sar CGC CTG TTT ATC AAA AAC AT (Palumbi 1996) and 16S 972R CCG GTC TGA ACT CAG ATC ATG T (Dayrat et al. 2011a) for 16S; 12Sa-H GAG GGT GAC GGG CGG TGT GT and 12Sai AAA CTA GGA TTA GAT ACC CTA TTA T (Palumbi 1996) for 12S. Portions of two nuclear genes (ITS2, 28S) were amplified with the following primers (all 5'-3'): LSU-1 CTA GCT GCG AGA ATT AAT GTG A and LSU-3 ACT TTC CCT CAC GGT ACT TG (Wade \& Mordan 2000) for ITS2; 28SC1 ACC CGC TGA ATT TAA GCA T (Hassouna et al. 1984) and 28SD3 GAC GAT CGA TTT GCA CGT CA (Vonnemann et al. 2005 ) for $28 \mathrm{~S}$. The $25 \mu \mathrm{l}$ PCRs (COI and $16 \mathrm{~S}$ ) contained $15.8 \mu \mathrm{l}$ of water, $2.5 \mu \mathrm{l}$ of $10 \times$ PCR buffer, $1.5 \mu \mathrm{l}$ of $25 \mathrm{mM} \mathrm{MgCl}_{2}, 0.5 \mu \mathrm{l}$ of each $10 \mu \mathrm{M}$ primer, $2 \mu \mathrm{l}$ of dNTP mixture, $0.2 \mu \mathrm{l}$ (1 unit) of TaKaRa Taq (code no. R001A), $1 \mu \mathrm{l}$ of $20 \mathrm{ng} / \mu \mathrm{l}$ template DNA and $1 \mu \mathrm{l}$ of $100 \times$ BSA (Bovine Serum Albumin). The $24.5 \mu \mathrm{l}$ PCR (12S) was identical except that the salt and the $100 \times$ BSA were replaced by $4 \mu 1$ Q-solution (with $\mathrm{MgCl}_{2}$ ). The PCR for ITS2 used the reagents in the same amounts as COI, 16S and $12 \mathrm{~S}$, except that water was reduced to $14.8 \mu \mathrm{l}$ and the amount of $100 \times$ BSA was increased to $2 \mu \mathrm{l}$. The PCRs for $28 \mathrm{~S}$ included $14.8 \mu \mathrm{l}$ of water, $2.5 \mu \mathrm{l}$ of $10 \times$ PCR buffer, $0.5 \mu \mathrm{l}$ of each $10 \mu \mathrm{M}$ primer, $1 \mu \mathrm{l}$ of dNTP mixture, $5 \mu \mathrm{l}$ of Q solution (which includes $\mathrm{MgCl}_{2}$ ) and $0.5 \mu \mathrm{l}$ of $20 \mathrm{ng} / \mu \mathrm{l}$ template DNA. The thermoprofile used for COI and $16 \mathrm{~S}$ was: 5 minutes at $94^{\circ} \mathrm{C} ; 30$ cycles of 40 seconds at $94^{\circ} \mathrm{C}, 1$ minute at $46^{\circ} \mathrm{C}$ and 1 minute at $72^{\circ} \mathrm{C}$; and 10 minutes at $72^{\circ} \mathrm{C}$. The thermoprofile used for $12 \mathrm{~S}$ was identical except that it ran for 40 cycles. The thermoprofile used for ITS2 was: 1 minute at $96^{\circ} \mathrm{C} ; 35$ cycles of 30 seconds at $94^{\circ} \mathrm{C}, 30$ seconds at $50^{\circ} \mathrm{C}$ and 1 minute at $72^{\circ} \mathrm{C}$; and a final extension of 10 minutes at $72^{\circ} \mathrm{C}$. The thermoprofile used for $28 \mathrm{~S}$ was: 4 minutes at $94^{\circ} \mathrm{C} ; 38$ cycles of 50 seconds at $94^{\circ} \mathrm{C}$, 1 minute at $52^{\circ} \mathrm{C}$ and 2 minutes 30 seconds at $72^{\circ} \mathrm{C}$; and a final extension of 10 minutes at $72^{\circ} \mathrm{C}$. The PCR products were cleaned with ExoSAP-IT (Affymetrix, Santa Clara, CA, USA) prior to sequencing. Untrimmed sequence fragments represented approximately $680 \mathrm{bp}$ for COI, $530 \mathrm{bp}$ for $16 \mathrm{~S}, 360 \mathrm{bp}$ for $12 \mathrm{~S}, 740 \mathrm{bp}$ for ITS2 and $1000 \mathrm{bp}$ for $28 \mathrm{~S}$.

\section{Phylogenetic analyses}

Chromatograms were consulted to resolve rare ambiguous base calls. Sequences were aligned using Clustal W in MEGA 6 (Tamura et al. 2013). Eight onchidiid species were selected as outgroups: Onchidella floridana (Dall, 1885), Peronina tenera (Stoliczka, 1869), Peronia sp. (Okinawa), Peronia sp. (Hawaii), Onchidina australis (Semper, 1880), Onchidium stuxbergi (Westerlund, 1883), O. typhae Buchannan, 1800 and Platevindex luteus (Semper, 1880). Outgroup sequences are from previous studies from our lab (Dayrat et al. 2011a, 2016, 2017; Dayrat \& Goulding 2017) or new. Analyses were not run enforcing the a priori monophyly of Paromoionchis sequences. Other (unpublished) analyses were performed using different combinations of outgroups, which all yielded identical results.

DNA sequences were all deposited in GenBank and vouchers deposited in museum collections (Table 1). The ends of each alignment were trimmed and sequences were concatenated. The COI alignment included 582 nucleotide positions. The concatenated COI, $16 \mathrm{~S}$ and $12 \mathrm{~S}$ alignment included a total of 1321 nucleotide positions: 582 (COI), 398 (16S) and 341 (12S). The ITS2 alignment included 850 
Table 1. (continued on next three pages) GenBank accession numbers for COI, 16S, 12S, ITS2 and 28S DNA sequences. All sequences are new, except the COI and 16S sequences of six of the seven outgroups (Dayrat et al. 2011a, 2016; Dayrat \& Goulding 2017) and three COI sequences of $P$. tumidus (unit \#1) from mainland China found in GenBank (misidentified as Paraoncidium reevesii (J.E. Gray, 1850) in Sun et al. 2014).

\begin{tabular}{|c|c|c|c|c|c|c|c|}
\hline $\begin{array}{c}\text { Species } \\
\text { (mitochondrial unit) }\end{array}$ & $\begin{array}{l}\text { Individual } \\
\text { (DNA \#) }\end{array}$ & Locality & COI & $16 S$ & $12 S$ & ITS2 & $28 \mathrm{~S}$ \\
\hline Onchidella floridana & 713 & Tobago & HQ660035 & HQ659903 & MG971017 & - & - \\
\hline Peronina tenera & 960 & Peninsular Malaysia & - & - & - & MG958840 & MG958874 \\
\hline Peronia sp. & 696 & Okinawa, Japan & HQ660043 & HQ659911 & MG971015 & MG958871 & MG958883 \\
\hline Peronia sp. & 706 & Hawaii, USA & HQ660038 & HQ659906 & MG971016 & MG958722 & MG971212 \\
\hline Platevindex luteus & 1001 & Singapore & MG958714 & MG958716 & MG971010 & MG958718 & MG958888 \\
\hline Onchidina australis & 1523 & NSW, Australia & KX179548 & KX179561 & MG971012 & MG958719 & MG971209 \\
\hline Onchidium typhae & 965 & Peninsular Malaysia & KX179509 & KX179525 & MG971013 & MG958720 & MG971210 \\
\hline Onchidium stuxbergi & 5605 & Vietnam & KX179520 & KX179537 & MG971014 & MG958721 & MG971211 \\
\hline P. tumidus unit \#1 & 928 & Peninsular Malaysia & MH054945 & - & - & MH055193 & - \\
\hline- & 963 & Peninsular Malaysia & МH054946 & MH055101 & MH055147 & MH055194 & MH055266 \\
\hline- & 1035 & Brunei Darussalam & МH054947 & - & - & - & - \\
\hline- & 1036 & Brunei Darussalam & MH054948 & MH055102 & MH055148 & MH055195 & MH055267 \\
\hline- & 1062 & Brunei Darussalam & МH054949 & - & - & - & - \\
\hline- & 1119 & Andaman, India & MH054950 & MH055103 & MH055149 & - & - \\
\hline- & 1732 & Sumatra, Indonesia & MH054951 & MH055104 & MH055150 & MH055196 & MH055268 \\
\hline- & 1754 & Sumatra, Indonesia & MH054952 & - & - & - & - \\
\hline- & 1755 & Sumatra, Indonesia & MH054953 & - & - & - & - \\
\hline- & 1798 & Sumatra, Indonesia & MH054954 & - & - & - & - \\
\hline- & 2200 & Sulawesi, Indonesia & MH054955 & - & - & - & - \\
\hline- & 2201 & Sulawesi, Indonesia & MH054956 & - & - & - & - \\
\hline- & 2240 & Sulawesi, Indonesia & MH054957 & - & - & MH055197 & - \\
\hline- & 2345 & Sulawesi, Indonesia & MH054958 & - & - & - & - \\
\hline- & 2355 & Sulawesi, Indonesia & MH054959 & - & - & - & - \\
\hline- & 2839 & Ambon, Indonesia & MH054960 & - & - & - & - \\
\hline- & 2840 & Ambon, Indonesia & MH054961 & MH055105 & MH055151 & MH055198 & MH055269 \\
\hline- & 3541 & Ambon, Indonesia & MH054962 & - & - & - & - \\
\hline- & 2832 & Ambon, Indonesia & MH054963 & - & - & - & - \\
\hline- & 2874 & Seram, Indonesia & MH054964 & - & - & MH055199 & - \\
\hline- & 2875 & Seram, Indonesia & MH054965 & - & - & MH055200 & - \\
\hline- & 2950 & Lombok, Indonesia & MH054966 & - & - & MH055201 & - \\
\hline- & 2952 & Lombok, Indonesia & MH054967 & - & - & - & - \\
\hline- & 2961 & Lombok, Indonesia & МH054968 & - & - & - & - \\
\hline- & 3051 & Bali, Indonesia & MH054969 & - & - & - & - \\
\hline- & 3070 & Bali, Indonesia & MH054970 & - & - & - & - \\
\hline- & 5042 & Halmahera, Indonesia & MH054971 & - & - & - & - \\
\hline- & 5082 & Halmahera, Indonesia & MH054972 & - & - & - & - \\
\hline- & 5102 & Halmahera, Indonesia & MH054973 & - & - & MH055202 & - \\
\hline- & 5103 & Halmahera, Indonesia & MH054974 & - & - & - & - \\
\hline- & 3171 & Luzon, Philippines & МH054975 & - & - & - & - \\
\hline- & 3192 & Luzon, Philippines & МH054976 & - & - & - & - \\
\hline
\end{tabular}


DAYRAT B. et al., A new genus of mangrove onchidiid slugs

Table 1. (continued) GenBank accession numbers for COI, 16S, 12S, ITS2 and 28S DNA sequences.

\begin{tabular}{|c|c|c|c|c|c|c|c|}
\hline $\begin{array}{c}\text { Species } \\
\text { (mitochondrial unit) }\end{array}$ & $\begin{array}{l}\text { Individual } \\
\text { (DNA \#) }\end{array}$ & Locality & COI & $16 S$ & $12 S$ & ITS2 & $28 \mathrm{~S}$ \\
\hline P. tumidus unit \#1 & 3200 & Luzon, Philippines & MH054977 & MH055106 & MH055152 & - & MH055270 \\
\hline- & 3205 & Luzon, Philippines & MH054978 & - & - & MH055203 & - \\
\hline- & 3222 & Luzon, Philippines & MH054979 & - & - & MH055204 & - \\
\hline- & 3344 & Bohol, Philippines & МH054980 & - & - & MH055205 & - \\
\hline- & 3371 & Bohol, Philippines & MH054981 & - & - & MH055206 & - \\
\hline- & 3416 & Bohol, Philippines & MH054982 & - & - & - & - \\
\hline- & 3761 & Japan & МH054983 & MH055107 & МH055153 & MH055207 & MH055271 \\
\hline- & 5619 & Vietnam & МH054984 & - & - & - & - \\
\hline- & 5642 & Vietnam & MH054985 & - & - & - & - \\
\hline- & 5682 & Vietnam & MH054986 & - & - & - & - \\
\hline- & 1522 & NSW, Australia & МH054987 & - & - & - & - \\
\hline- & 1528 & NSW, Australia & МH054988 & MH055108 & MH055154 & МH055208 & MH055272 \\
\hline- & 1529 & NSW, Australia & MH054989 & - & - & - & - \\
\hline- & 1530 & NSW, Australia & МH054990 & - & - & - & - \\
\hline- & 1634 & NT, Australia & MH054991 & - & - & MH055209 & - \\
\hline- & 1645 & NT, Australia & MH054992 & МH055109 & MH055155 & - & - \\
\hline- & 1686 & NT, Australia & МH054993 & - & - & - & - \\
\hline- & 1705 & NT, Australia & MH054994 & - & - & MH055210 & - \\
\hline- & 1531 & Queensland, Australia & MH054995 & MH055110 & MH055156 & - & - \\
\hline- & 2562 & Queensland, Australia & МH054996 & - & - & - & - \\
\hline- & 2602 & Queensland, Australia & MH054997 & - & - & - & - \\
\hline- & 2627 & Queensland, Australia & MH054998 & - & - & - & - \\
\hline- & 2637 & Queensland, Australia & MH054999 & - & - & - & - \\
\hline- & 2652 & Queensland, Australia & MH055000 & - & - & - & - \\
\hline- & 2657 & Queensland, Australia & MH055001 & - & - & - & - \\
\hline- & 2701 & Queensland, Australia & MH055002 & - & - & - & - \\
\hline- & - & China & JN543146 & - & - & - & - \\
\hline- & - & China & JN543150 & - & - & - & - \\
\hline- & - & China & JN543151 & - & - & - & - \\
\hline P. tumidus unit \#2 & 1638 & NT, Australia & MH055003 & - & - & - & - \\
\hline- & 1651 & NT, Australia & MH055004 & MH055111 & MH055157 & - & - \\
\hline- & 1794 & Sumatra, Indonesia & MH055005 & MH055112 & MH055158 & - & MH055273 \\
\hline- & 2960 & Lombok, Indonesia & MH055006 & МH055113 & МH055159 & МH055211 & MH055274 \\
\hline- & 3172 & Luzon, Philippines & MH055007 & МH055114 & MH055160 & MH055212 & MH055275 \\
\hline- & 3202 & Luzon, Philippines & MH055008 & - & - & MH055213 & - \\
\hline- & 3229 & Luzon, Philippines & МH055009 & MH055115 & MH055161 & MH055214 & MH055276 \\
\hline- & 3237 & Luzon, Philippines & МH055010 & - & - & МH055215 & - \\
\hline- & 3610 & Luzon, Philippines & MH055011 & - & - & MH055216 & - \\
\hline P. tumidus unit \#3 & 5432 & Papua New Guinea & MH055012 & MH055116 & MH055162 & МH055217 & MH055277 \\
\hline- & 5433 & Papua New Guinea & MH055013 & MH055117 & MH055163 & MH055218 & MH055278 \\
\hline P. boholensis unit \#1 & 3283 & Bohol, Philippines & МH055014 & МH055118 & MH055164 & МH055219 & MH055279 \\
\hline- & $3288 \mathrm{H}$ & Bohol, Philippines & MH055015 & - & - & MH055220 & MH055280 \\
\hline- & 3369 & Bohol, Philippines & MH055016 & - & - & MH055221 & - \\
\hline
\end{tabular}


Table 1. (continued) GenBank accession numbers for COI, 16S, 12S, ITS2 and 28S DNA sequences.

\begin{tabular}{|c|c|c|c|c|c|c|c|}
\hline $\begin{array}{c}\text { Species } \\
\text { (mitochondrial unit) }\end{array}$ & $\begin{array}{l}\text { Individual } \\
\text { (DNA \#) }\end{array}$ & Locality & COI & $16 S$ & $12 \mathrm{~S}$ & ITS2 & $28 S$ \\
\hline P. boholensis unit \#1 & 3372 & Bohol, Philippines & MH055017 & MH055119 & MH055165 & MH055222 & MH055281 \\
\hline- & 3411 & Bohol, Philippines & МH055018 & - & - & MH055223 & - \\
\hline- & 3412 & Bohol, Philippines & MH055019 & MH055120 & MH055166 & MH055224 & MH055282 \\
\hline- & 3413 & Bohol, Philippines & MH055020 & - & - & MH055225 & - \\
\hline- & 3417 & Bohol, Philippines & MH055021 & - & - & MH055226 & - \\
\hline- & 3422 & Bohol, Philippines & MH055022 & MH055121 & MH055167 & MH055227 & MH055283 \\
\hline- & 3423 & Bohol, Philippines & MH055023 & - & - & MH055228 & - \\
\hline- & 3619 & Bohol, Philippines & MH055024 & - & - & MH055229 & - \\
\hline- & 3609 & Luzon, Philippines & MH055025 & MH055122 & MH055168 & MH055230 & MH055284 \\
\hline P. boholensis unit \#2 & 2128 & NE Sulawesi, Indonesia & MH055026 & - & - & - & - \\
\hline- & 2129 & NE Sulawesi, Indonesia & MH055027 & MH055123 & MH055169 & MH055231 & MH055285 \\
\hline- & 2175 & NE Sulawesi, Indonesia & MH055028 & - & - & MH055232 & - \\
\hline - & 2199 & NE Sulawesi, Indonesia & MH055029 & - & - & - & - \\
\hline- & 2316 & NE Sulawesi, Indonesia & МH055030 & MH055124 & MH055170 & - & - \\
\hline- & 2360 & SE Sulawesi, Indonesia & МH055031 & - & - & - & - \\
\hline- & 2849 & Ambon, Indonesia & MH055032 & - & - & - & - \\
\hline- & 2850 & Ambon, Indonesia & MH055033 & - & - & - & - \\
\hline- & 2851 & Ambon, Indonesia & MH055034 & MH055125 & MH055171 & MH055233 & MH055286 \\
\hline- & 2884 & Seram, Indonesia & MH055035 & - & - & MH055234 & - \\
\hline- & 2896 & Kei, Indonesia & MH055036 & MH055126 & MH055172 & - & - \\
\hline- & 2901 & Kei, Indonesia & MH055037 & - & - & - & - \\
\hline- & 2903 & Kei, Indonesia & MH055038 & - & - & MH055235 & - \\
\hline- & 2911 & Kei, Indonesia & MH055039 & - & - & - & - \\
\hline- & 2935 & Kei, Indonesia & MH055040 & - & - & MH055236 & - \\
\hline- & 2937 & Kei, Indonesia & MH055041 & - & - & - & - \\
\hline- & 3565 & Kei, Indonesia & MH055042 & - & - & MH055237 & - \\
\hline- & 3117 & Bali, Indonesia & MH055043 & MH055127 & MH055173 & MH055238 & MH055287 \\
\hline - & 5019 & Halmahera, Indonesia & MH055044 & MH055128 & MH055174 & MH055239 & MH055288 \\
\hline- & 5140 & Halmahera, Indonesia & MH055045 & - & - & - & - \\
\hline- & 5146 & Halmahera, Indonesia & МH055046 & - & - & - & - \\
\hline P. daemelii & 1510 & NSW, Australia & MH055047 & - & - & MH055240 & - \\
\hline- & 1511 & NSW, Australia & МH055048 & MH055129 & MH055175 & MH055241 & MH055289 \\
\hline- & 1512 & NSW, Australia & MH055049 & - & - & MH055242 & - \\
\hline- & 1514 & NSW, Australia & MH055050 & - & - & MH055243 & - \\
\hline- & 1515 & NSW, Australia & MH055051 & - & - & MH055244 & - \\
\hline- & 1518 & NSW, Australia & MH055052 & MH055130 & MH055176 & - & - \\
\hline- & 1519 & NSW, Australia & MH055053 & - & - & MH055245 & - \\
\hline- & 1521 & NSW, Australia & MH055054 & MH055131 & MH055177 & MH055246 & MH055290 \\
\hline- & 1532 & Queensland, Australia & MH055055 & MH055132 & MH055178 & - & - \\
\hline- & 1533 & Queensland, Australia & МH055056 & - & - & MH055247 & - \\
\hline- & 2668 & Queensland, Australia & MH055057 & MH055133 & MH055179 & МH055248 & МH055291 \\
\hline
\end{tabular}


DAYRAT B. et al., A new genus of mangrove onchidiid slugs

Table 1. (continued) GenBank accession numbers for COI, 16S, 12S, ITS2 and 28S DNA sequences.

\begin{tabular}{|c|c|c|c|c|c|c|c|}
\hline $\begin{array}{c}\text { Species } \\
\text { (mitochondrial unit) }\end{array}$ & $\begin{array}{l}\text { Individual } \\
\text { (DNA \#) }\end{array}$ & Locality & COI & $16 S$ & $12 S$ & ITS2 & $28 S$ \\
\hline P. penangensis & 1086 & Andaman Islands, India & MH055058 & MH055134 & MH055180 & - & - \\
\hline- & 1100 & Andaman Islands, India & MH055059 & - & - & - & - \\
\hline- & 1101 & Andaman Islands, India & MH055060 & - & - & - & - \\
\hline- & 1117 & Andaman Islands, India & MH055061 & MH055135 & MH055181 & - & - \\
\hline- & 1118 & Andaman Islands, India & MH055062 & - & - & - & - \\
\hline- & 1129 & Andaman Islands, India & MH055063 & - & - & - & - \\
\hline- & 1130 & Andaman Islands, India & MH055064 & - & - & - & - \\
\hline- & 1167 & Western India & MH055065 & - & - & - & - \\
\hline- & 1173 & Western India & MH055066 & MH055136 & MH055182 & - & - \\
\hline- & 1175 & Western India & MH055067 & - & - & - & - \\
\hline- & 1176 & Western India & MH055068 & - & - & - & - \\
\hline- & 1177 & Western India & MH055069 & - & - & - & - \\
\hline- & 1182 & Western India & MH055070 & - & - & - & - \\
\hline- & 5990 & Peninsular Malaysia & MH055071 & - & - & - & - \\
\hline- & 5991 & Peninsular Malaysia & MH055072 & - & - & MH055249 & - \\
\hline- & 6020 & Peninsular Malaysia & MH055073 & - & - & MH055250 & - \\
\hline- & 6031 & Peninsular Malaysia & MH055074 & - & - & MH055251 & - \\
\hline- & 6033 & Peninsular Malaysia & МH055075 & - & - & МH055252 & - \\
\hline- & $6037 \mathrm{H}$ & Peninsular Malaysia & MH055076 & - & - & MH055253 & MH055292 \\
\hline- & 6039 & Peninsular Malaysia & MH055077 & - & - & MH055254 & - \\
\hline- & 957 & Peninsular Malaysia & MH055078 & MH055137 & MH055183 & MH055255 & MH055293 \\
\hline- & 958 & Peninsular Malaysia & MH055079 & MH055138 & MH055184 & MH055256 & MH055294 \\
\hline P. goslineri unit \#1 & 3221 & Luzon, Philippines & MH055080 & MH055139 & MH055185 & MH055257 & MH055295 \\
\hline- & 3232 & Luzon, Philippines & MH055081 & MH055140 & MH055186 & MH055258 & MH055296 \\
\hline- & $3233 \mathrm{H}$ & Luzon, Philippines & MH055082 & MH055141 & MH055187 & MH055259 & MH055297 \\
\hline- & 6049 & Luzon, Philippines & MH055083 & - & - & MH055260 & - \\
\hline P. goslineri unit \#2 & 2210 & Sulawesi, Indonesia & MH055084 & MH055142 & MH055188 & MH055261 & MH055298 \\
\hline- & 2241 & Sulawesi, Indonesia & MH055085 & MH055143 & MH055189 & - & - \\
\hline- & 3060 & Bali, Indonesia & MH055086 & - & - & - & - \\
\hline- & 3066 & Bali, Indonesia & MH055087 & MH055144 & MH055190 & - & - \\
\hline- & 3068 & Bali, Indonesia & MH055088 & - & - & MH055262 & - \\
\hline- & 3072 & Bali, Indonesia & MH055089 & - & - & - & - \\
\hline- & 3074 & Bali, Indonesia & MH055090 & - & - & - & - \\
\hline- & 3078 & Bali, Indonesia & MH055091 & - & - & - & - \\
\hline- & 3079 & Bali, Indonesia & MH055092 & - & - & MH055263 & - \\
\hline- & 3118 & Bali, Indonesia & MH055093 & - & - & - & - \\
\hline- & 3120 & Bali, Indonesia & MH055094 & - & - & - & - \\
\hline- & 3555 & Ambon, Indonesia & MH055095 & MH055145 & MH055191 & - & - \\
\hline- & 5072 & Halmahera, Indonesia & MH055096 & - & - & - & - \\
\hline- & 5073 & Halmahera, Indonesia & MH055097 & MH055146 & MH055192 & MH055264 & MH055299 \\
\hline- & 5145 & Halmahera, Indonesia & MH055098 & - & - & MH055265 & - \\
\hline- & 5890 & Timor, Indonesia & MH055099 & - & - & - & - \\
\hline- & 5891 & Timor, Indonesia & MH055100 & - & - & - & - \\
\hline
\end{tabular}


nucleotide positions (including gaps). The concatenated ITS2 and 28S alignment included 1600 nucleotide positions. Four independent sets of analyses were performed: 1) Maximum Likelihood and Bayesian phylogenetic analyses with just COI sequences, performed with 159 individuals (not counting outgroups), i.e., all the 156 specimens examined here and 3 additional sequences obtained from GenBank; 2) Maximum Likelihood and Bayesian phylogenetic analyses with concatenated mitochondrial COI, $16 \mathrm{~S}$ and $12 \mathrm{~S}$ sequences for a subset of 46 individuals (not counting outgroups); 3) Maximum Parsimony analyses with concatenated nuclear ITS2 and 28S sequences for a subset of 34 individuals (not counting outgroups); 4) Maximum Parsimony analyses with only ITS2 sequences, performed with 73 individuals (not counting outgroups).

Prior to Maximum Likelihood and Bayesian analyses, the best-fitting evolutionary model was selected independently for each marker using the Model Selection option of Topali ver. 2.5 (Milne et al. 2004). A GTR + G model was independently selected for each mitochondrial marker and a HKY + G model was independently selected for each nuclear marker. Other (unpublished) analyses were performed using different models, which all yielded identical results. Maximum Likelihood analyses were performed using PhyML (Guindon \& Gascuel 2003) as implemented in Topali. Node support was evaluated using bootstrapping with 100 replicates. Bayesian analyses were performed using MrBayes ver. 3.1.2 (Ronquist \& Huelsenbeck 2003) as implemented in Topali, with five simultaneous runs of $1.5 \times 10^{6}$ generations each, sample frequency of 100 and burn-in of $25 \%$ (posterior probabilities were also calculated). Topali did not detect any issue with respect to convergence. Maximum Parsimony analyses were conducted in PAUP ver. 4.0 (Swofford 2002), with gaps coded as a $5^{\text {th }}$ character state and 100 bootstrap replicates conducted using a full heuristic search. All analyses were run several times and yielded the same result. In addition, pairwise genetic distances between COI sequences were calculated in MEGA 6. COI sequences were also translated into amino acid sequences in MEGA using the invertebrate mitochondrial genetic code to check for the presence of stop codons (no stop codon was found).

\section{Results}

\section{Molecular phylogenetic analyses}

DNA sequences were used to test species limits within Paromoionchis gen. nov. The monophyly of this genus is strongly supported in all analyses (Figs 1-4). In analyses based on mitochondrial COI, 16S and $12 \mathrm{~S}$ concatenated sequences, three clades (clades A, B and C in Fig. 1) are strongly supported, with bootstrap support and posterior probabilities of 88 and 1, 100 and 1, and 100 and 1, respectively. The relationships between clades A, B and C are not well supported. Each of these three clades includes three strongly-supported, least-inclusive units that are reciprocally monophyletic (Fig. 1). The monophyly of each unit is strongly supported by a bootstrap support of 100 and a posterior probability of 1 ; the bootstrap support for $P$. goslineri gen. et sp. nov. unit \#1 is 98 (Fig. 1).

The phylogenetic analyses with just COI yielded similar results, even though, as expected, the deeper nodes are not as strongly supported (Fig. 2). The monophyly of Paromoionchis gen. nov. is recovered but not well supported. The monophyly of clades A, B and C is strongly supported with the following values (bootstrap/posterior probabilities): 91/0.99, 94/1 and 92/1. The monophyly of each of the nine units is also strongly supported: 100/1 (P. goslineri gen. et sp. nov. unit \#2, P. penangensis gen. et sp. nov., P. daemelii, $P$. boholensis gen. et sp. nov. unit \#1, P. tumidus unit \#2 and P. tumidus unit \#1), 99/1 (P. boholensis gen. et sp. nov. unit \#2), 96/1 (P. tumidus unit \#3) and 85/0.95 (P. goslineri gen. et sp. nov. unit \#1). There is some phylogenetic structure within P. tumidus unit \#1 (which cannot be divided into strongly supported and reciprocally monophyletic subunits) but little to no structure within the eight other units (Fig. 2). 
DAYRAT B. et al., A new genus of mangrove onchidiid slugs

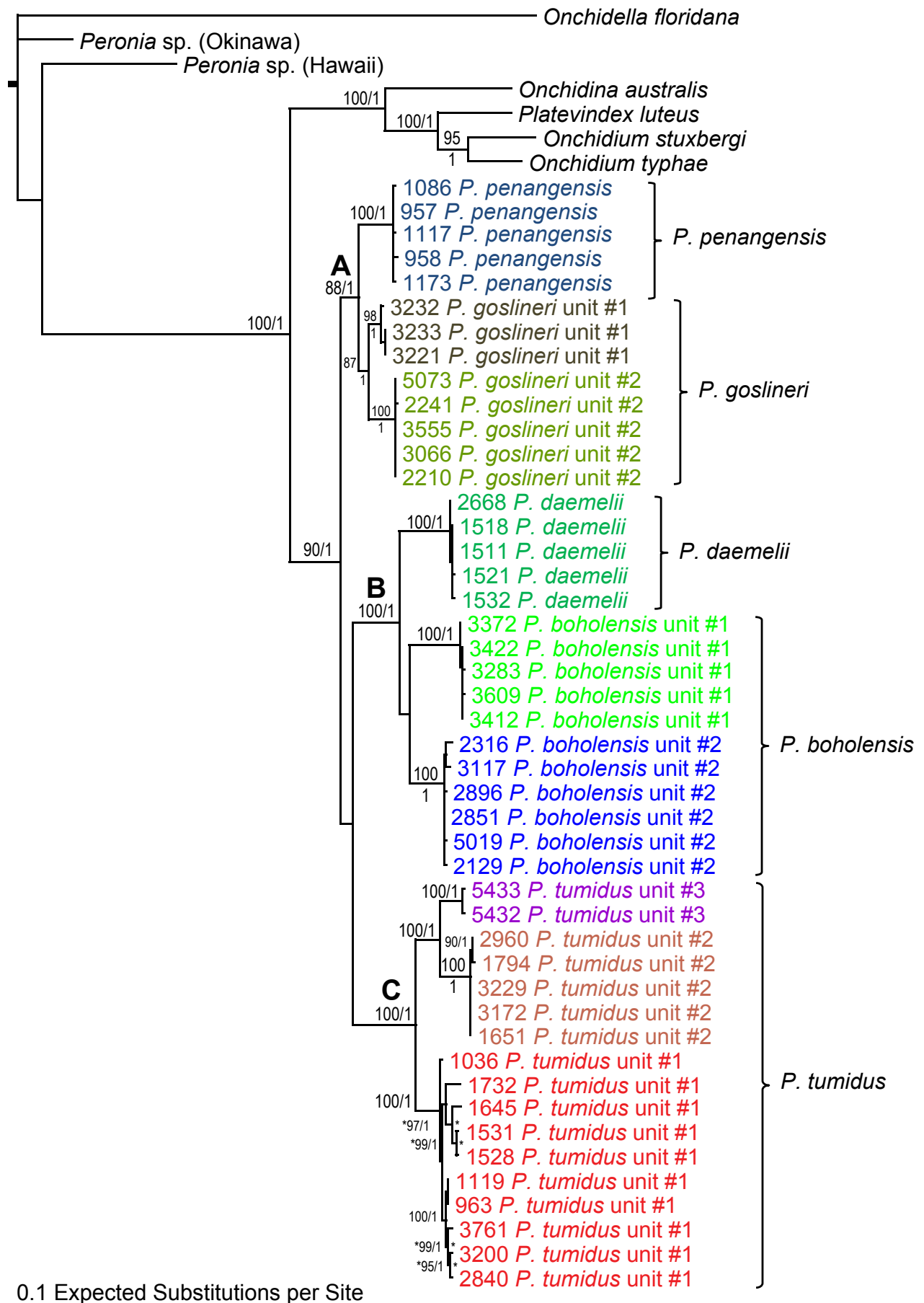

Fig. 1. Phylogenetic relationships within Paromoionchis gen. nov. based on concatenated COI, 16S and $12 \mathrm{~S}$ sequences for 53 individuals (including 7 outgroups). Numbers by the branches are the bootstrap values (maximum likelihood analysis, ML) and the posterior probabilities (Bayesian analysis). Only numbers $>70 \%$ (ML) and $>0.9$ (Bayesian) are indicated. Numbers for each individual correspond to unique identifiers for DNA extraction. All sequences for specimens of Paromoionchis gen. nov. are new. Some outgroup sequences are from previous studies (Dayrat et al. 2011a, 2016; Dayrat \& Goulding 2017). Information on specimens can be found in the lists of material examined and in Table 1. The letters A, B and C correspond to three clades which are referred to in the text. The color used for each (mitochondrial) unit is the same as that used in Figs 2-6. 


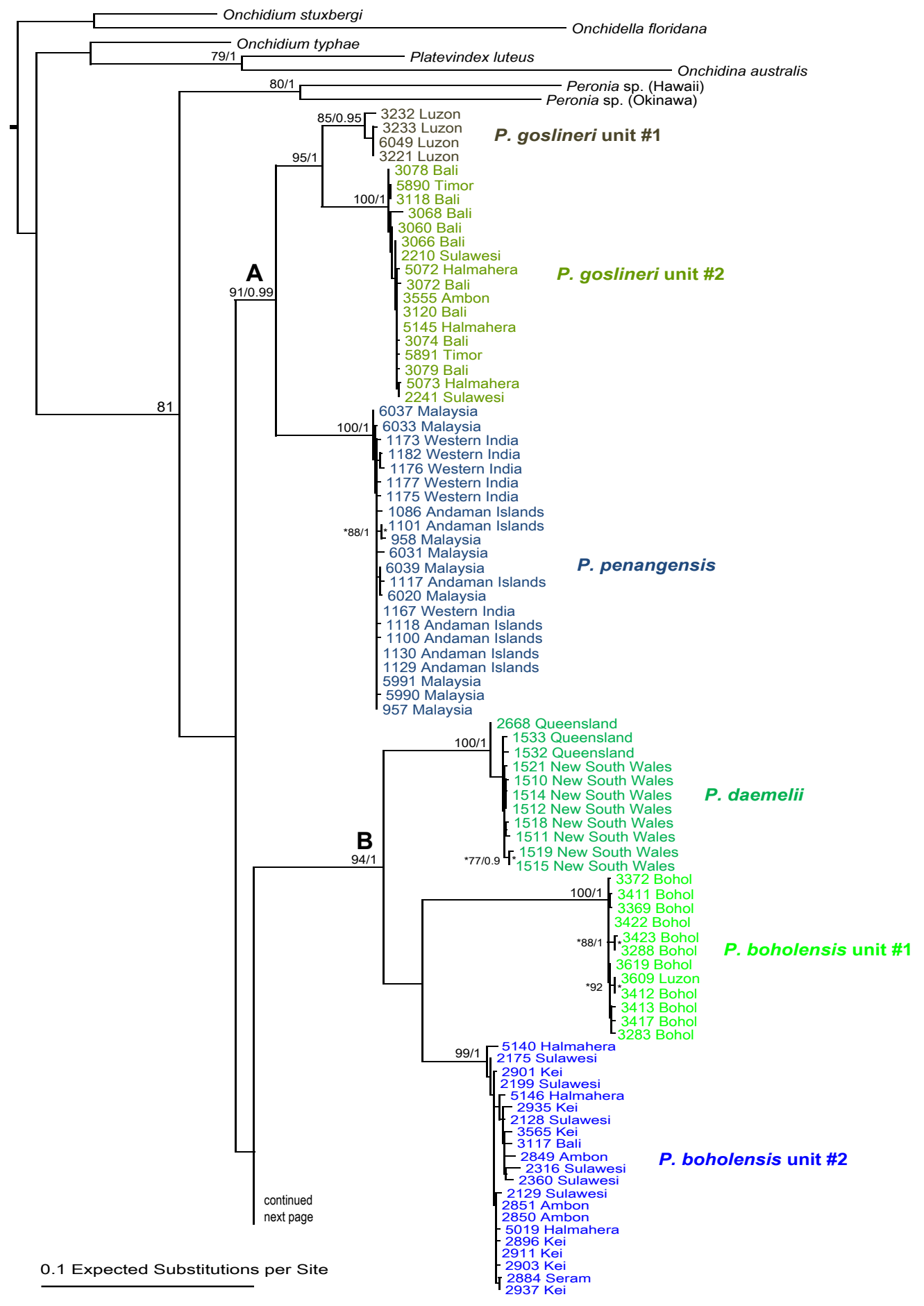

Fig. 2. (continued on next page) Phylogenetic relationships within Paromoionchis gen. nov. based on COI sequences of 166 individuals. Numbers by the branches are the bootstrap values (maximum likelihood analysis, ML) and the posterior probabilities (Bayesian analysis). Only numbers $>70 \%$ (ML) and $>0.9$ (Bayesian) are indicated. Numbers for each individual correspond to unique identifiers for DNA extraction. All sequences for specimens of Paromoionchis gen. nov. are new, except for the three sequences of P. tumidus (Semper, 1880) comb. nov. from China found in GenBank (in which they were misidentified as Paraoncidium reevesii (J.E. Gray, 1850)). Information on specimens can be found in the lists of material examined and in Table 1. The letters A, B and C correspond to three clades referred to in the text. The color used for each (mitochondrial) unit is the same as that used in Figs 1 and 3-6. 


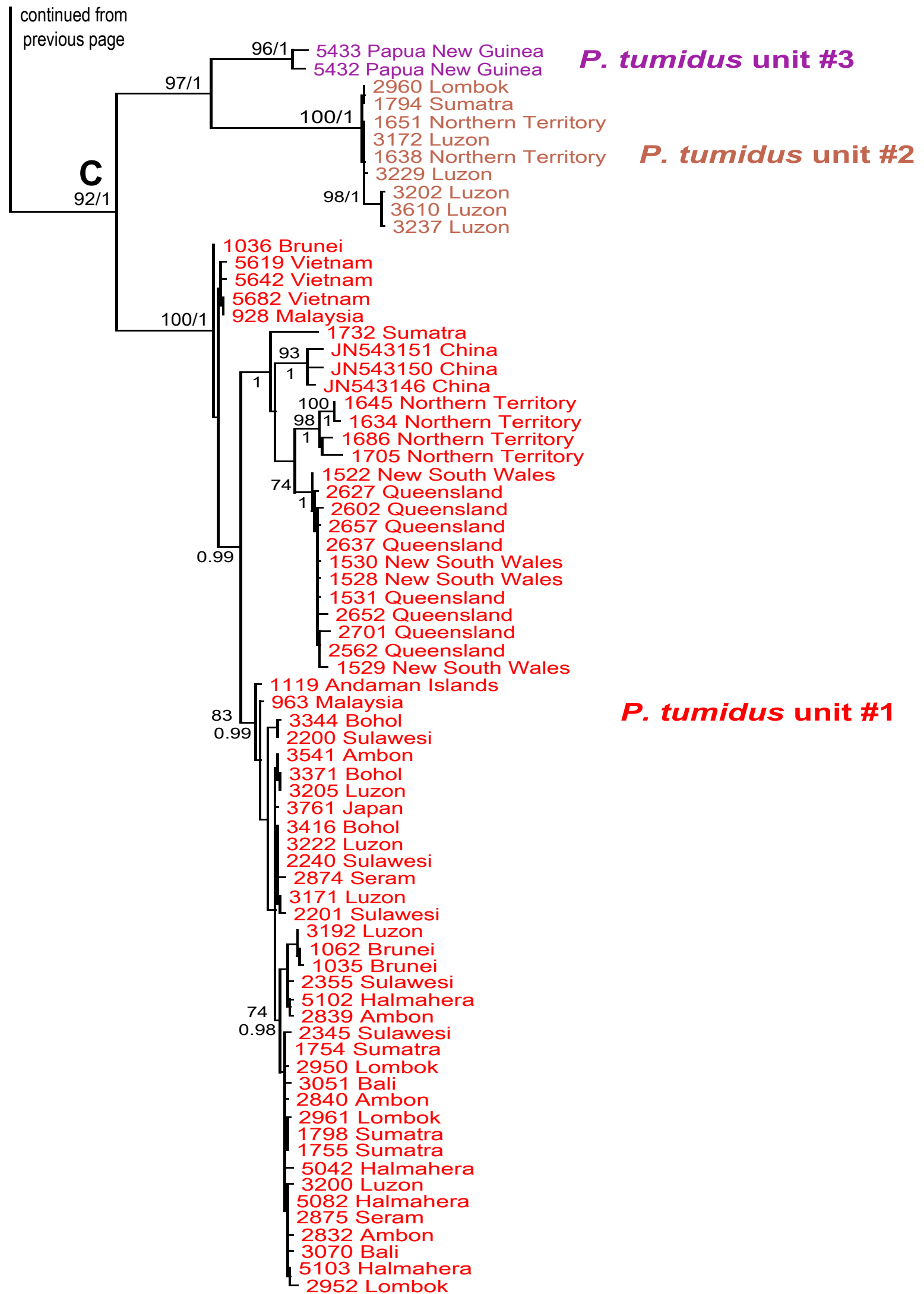

Fig. 2. (continued) Phylogenetic relationships within Paromoionchis gen. nov. based on COI sequences of 166 individuals. 


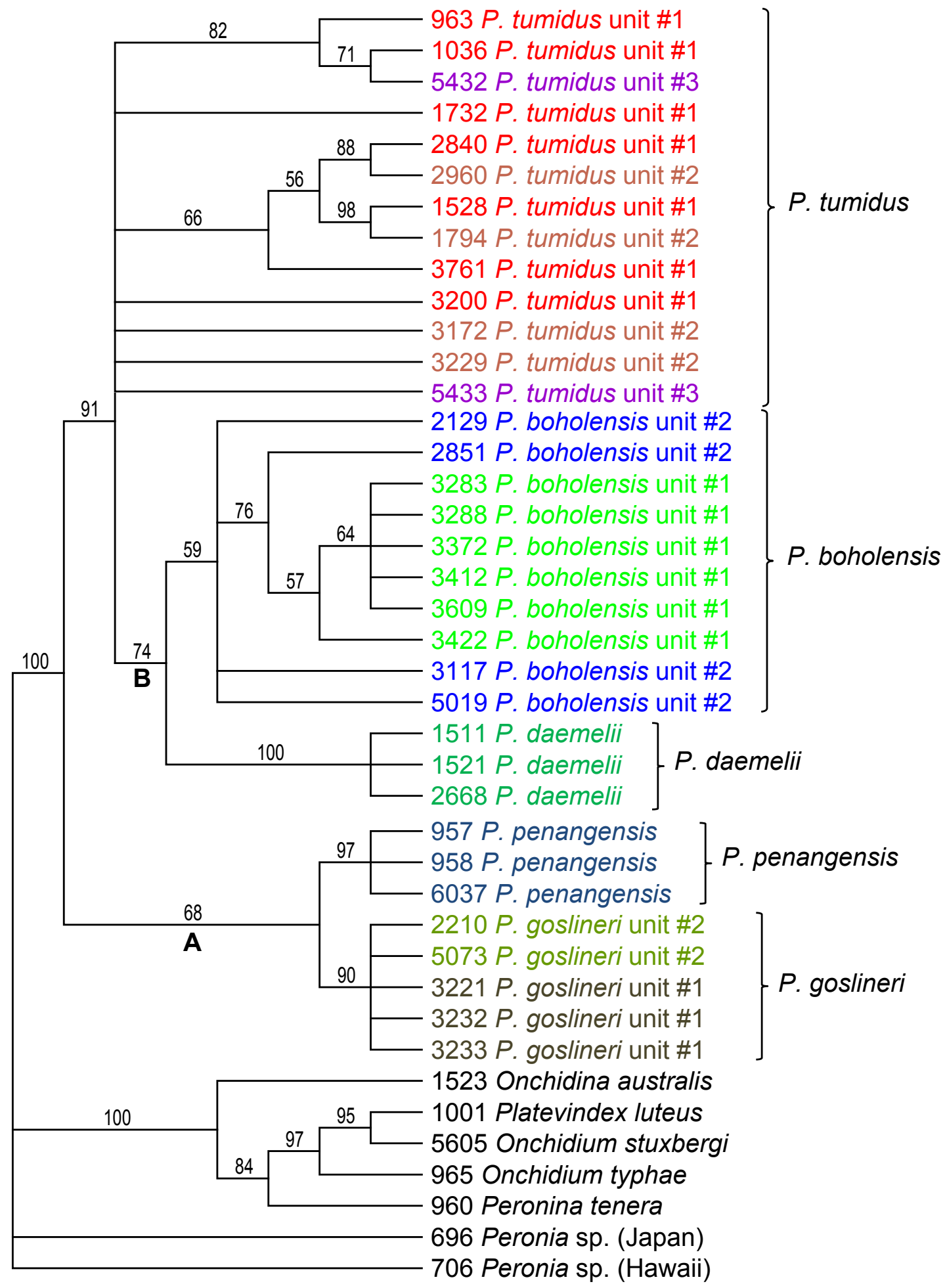

Fig. 3. Maximum parsimony consensus tree within Paromoionchis gen. nov., performed with concatenated ITS2 and 28S DNA sequences from 41 individuals (including 7 outgroups). Numbers by the branches are the bootstrap values (only numbers $>50 \%$ are indicated). Numbers for each individual correspond to unique identifiers for DNA extraction. All sequences for specimens of Paromoionchis gen. nov. are new. Information on specimens can be found in the lists of material examined and in Table 1. Letters A and B correspond to clades referred to in the text. The color used for each (mitochondrial) unit is the same as that used in Figs $1-2$ and 4-6. 
DAYRAT B. et al., A new genus of mangrove onchidiid slugs

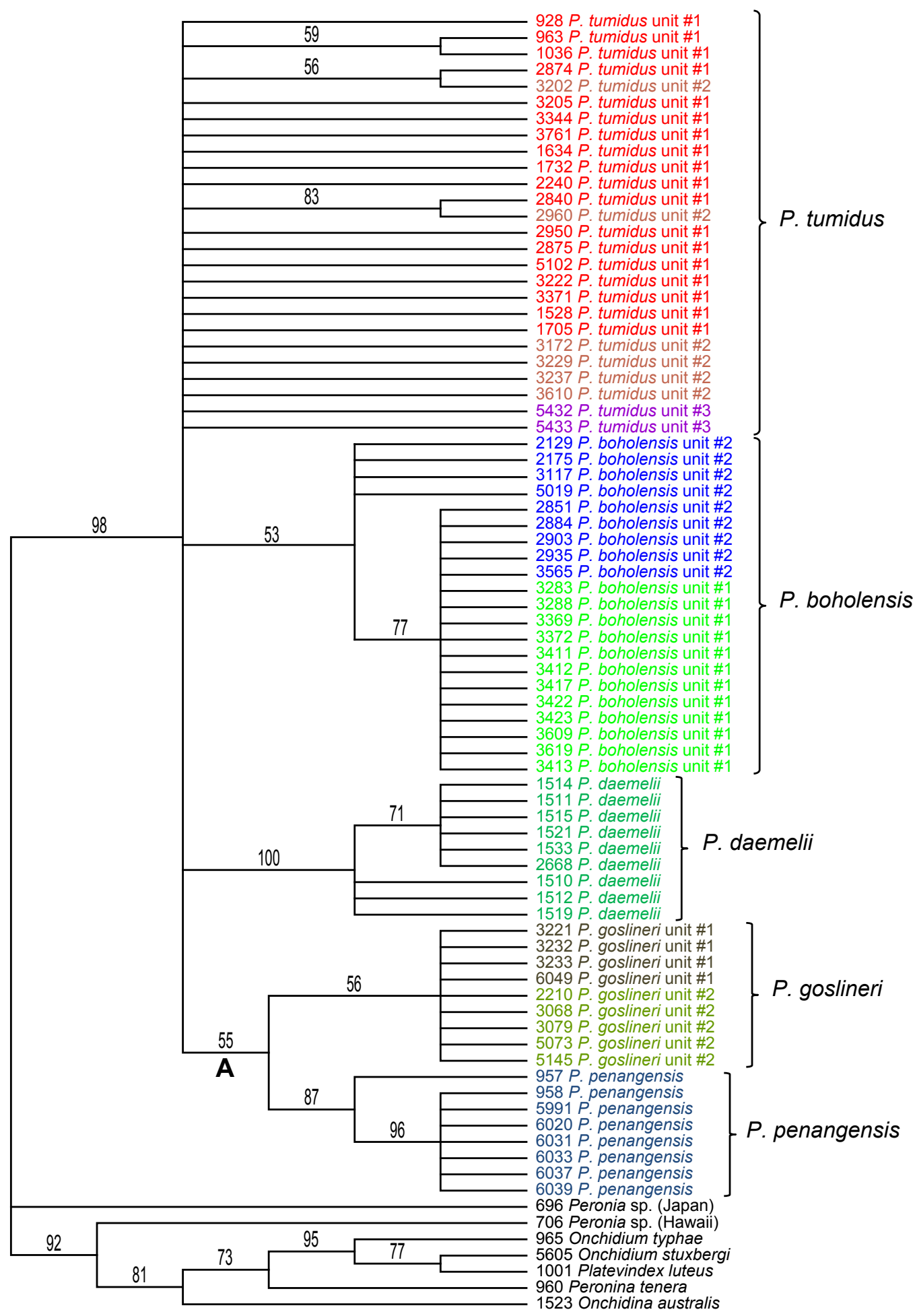

Fig. 4. Maximum parsimony consensus tree within Paromoionchis gen. nov., performed with ITS2 DNA sequences from 80 individuals (including 7 outgroups). Numbers by the branches are the bootstrap values (only numbers $>50 \%$ are indicated). Numbers for each individual correspond to unique identifiers for DNA extraction. All sequences for specimens of Paromoionchis gen. nov. are new. Information on specimens can be found in the lists of material examined and in Table 1. The letter A corresponds to a clade referred to in the text. The color used for each (mitochondrial) unit is the same as that used in Figs $1-3$ and $5-6$. 
Table 2. Pairwise genetic distances between individual sequences within and between mitochondrial units, based on our data set of 159 COI sequences (Table 1). Ranges of minimum to maximum distances are indicated (as percentages). For instance, within P. tumidus (Semper, 1880) unit \#1, individual sequences are between 0 and 3.2\% divergent; individual sequences between $P$. tumidus unit $\# 1$ and $P$. boholensis gen. et sp. nov. unit \#2 are minimally $6.4 \%$ and maximally $7.9 \%$ divergent; also, overall, the distance gap between $P$. tumidus unit \#1 and the eight other mitochondrial units is between $3.2 \%$ (the maximum intra-unit distance within $P$. tumidus unit \#1) and 5\% (the minimum distance between P. tumidus unit \#1 and P. tumidus unit \#3). The data from this table are illustrated in Figure 5 to help visualize the large gap between intra-specific and inter-specific distances.

\begin{tabular}{|c|c|c|c|c|c|c|c|c|c|}
\hline $\begin{array}{c}\text { Species } \\
\text { (mitochondrial unit) }\end{array}$ & tumid. 1 & boh. 2 & boh. 1 & daeme. & tumid. 2 & tumid. 3 & penan. & gosli. 2 & gosli. 1 \\
\hline P. tumidus unit \#1 & $0-3.2$ & & & & & & & & \\
\hline P. boholensis unit \#2 & $6.4-7.9$ & $0-1.3$ & & & & & & & \\
\hline P. boholensis unit \#1 & $6.8-8.1$ & $5.6-6.4$ & $0-0.5$ & & & & & & \\
\hline P. daemelii & $7.0-8.4$ & $5.0-5.8$ & $6.2-6.9$ & $0-0.8$ & & & & & \\
\hline P. tumidus unit \#2 & $5.7-7.2$ & $7.8-9.0$ & $7.9-8.9$ & $8.8-9.8$ & $0-0.6$ & & & & \\
\hline P. tumidus unit \#3 & $5.0-6.0$ & $7.1-7.8$ & $7.5-8.0$ & $8.3-8.8$ & $4.2-4.8$ & 0.6 & & & \\
\hline P. penangensis & $5.5-6.8$ & $6.6-7.6$ & $7.0-7.8$ & $7.1-7.8$ & $7.1-8.0$ & $6.3-6.8$ & $0-0.5$ & & \\
\hline P. goslineri unit \#2 & $5.9-7.4$ & $6.7-7.6$ & $7.3-8.3$ & $6.9-7.6$ & $7.4-8.2$ & $6.6-7.2$ & $4.7-5.4$ & $0-0.7$ & \\
\hline P. goslineri unit \#1 & $5.9-7.2$ & $6.2-7.3$ & $7.7-8.0$ & $6.9-7.6$ & $7.9-8.9$ & $6.5-6.7$ & $4.3-5.0$ & $3.4-3.8$ & $0-0.8$ \\
\hline
\end{tabular}

Nuclear sequences (ITS2 alone and ITS2 and 28S concatenated) yielded fewer monophyletic units than the mitochondrial sequences (Figs 3-4). Three units are highly supported (with bootstrap values $>90 \%$ ): $P$. daemelii, P. goslineri gen. et sp. nov. and P. penangensis gen. et sp. nov. One unit, P. boholensis gen. et sp. nov., is less strongly supported (with bootstrap values $>50 \%$ ) but is consistently recovered in all analyses with nuclear sequences. Finally, there is not enough phylogenetic signal to support the monophyly of $P$. tumidus, which, in the analyses based on nuclear sequences, includes a series of unresolved basal branches (Figs 3-4). Most importantly, individuals of the P. goslineri gen. et sp. nov. mitochondrial units \#1 and \#2 (Figs 1-2) are mixed together. Nuclear data do not support the existence of two distinct, reciprocally-monophyletic units within $P$. goslineri gen. et sp. nov. (Figs 3-4). The exact same remark applies to $P$. boholensis gen. et sp. nov. As for $P$. tumidus, individuals from the three mitochondrial units \#1, \#2 and \#3 are all mixed together as well, even though they represent unresolved branches at the base of the nuclear trees (Figs 3-4). Finally, support is generally low for deeper nodes with nuclear sequences (Figs 3-4): clade A (P. penangensis gen. et sp. nov. and P. goslineri gen. et sp. nov.) is recovered in both the analysis with ITS2 and $28 \mathrm{~S}$ concatenated and in the analysis with just ITS2; clade B ( $P$. daemelii and $P$. boholensis gen. et sp. nov.) is only recovered in the ITS2 and $28 \mathrm{~S}$ concatenated analysis; clade C ( $P$. tumidus units) is not recovered (as unresolved branches at the base of the tree).

\section{Pairwise genetic divergences}

Pairwise genetic distances (between COI sequences) also support the existence of nine least-inclusive molecular units of Paromoionchis gen. nov. and there is a wide and unambiguous gap between intra-unit and inter-unit distances (Table 2, Fig. 5). In seven of the units (i.e., all nine units but P. tumidus unit \#1 and $P$. boholensis gen. et sp. nov. unit \#2), the intra-unit distances are below $0.8 \%$ and the inter-unit distances vary from $3.4 \%$ (between $P$. goslineri gen. et sp. nov. unit $\# 1$ and $P$. goslineri gen. et sp. nov. unit \#2) to $9.8 \%$ (between $P$. daemelii and P. tumidus unit \#2). Data are similar for P. boholensis gen. et sp. nov. unit \#2, with intra-unit distances below $1.3 \%$ and inter-unit distances varying from 5.6 to $9.0 \%$. 
There also is a strong gap between intra- and inter-unit distances for P. tumidus unit \#1, but it is slightly shifted: intra-unit distances are below 3.4\% and inter-unit distances vary from 5.0 to $8.4 \%$. Genetic distances do not mean anything in absolute terms and one should not expect the gap between intra- and inter-unit distances to always be the same between genera and even within genera. It all depends on the context. In clade A, the gap is between $0.8 \%$ and $3.4 \%$ and inter-unit divergences do not exceed $8.9 \%$. In clade B, data display a similar pattern but numbers are slightly shifted, with a gap between $1.3 \%$ and $5 \%$ and inter-unit divergences going up to $9.8 \%$. Finally, in clade $\mathrm{C}$, the gap between intra- and inter-unit distances seems smaller if all three units are considered together (between 3.2\% and 4.2\%). However, in clade $\mathrm{C}$, distances need to be analyzed with $P$. tumidus unit \#1 being taken separately because of its higher intra-unit distances (up to 3.2\%). There is still an obvious gap in genetic distances between P. tumidus unit \#1 and unit \#3 (inter-unit distances above 5.0\%) and between P. tumidus unit \#1 and unit \#2 (inter-unit distances above 5.7\%). Finally, the gap is obvious between P. tumidus unit \#2 and unit \#3 (intra-unit distances below $0.6 \%$ and inter-unit distances above $4.2 \%$ ).

So, overall, there is always a gap between intra-unit and inter-unit distances, but the actual values vary depending on the phylogenetic context and the units being considered (Fig. 5). In other words, one should not focus on where the gap is situated (between $2 \%$ and $5 \%$, between $3 \%$ and $6 \%$, etc.) but on whether there is an actual gap separating units, especially those that are most closely related.

\section{Comparative anatomy}

In the field, specimens of Paromoionchis gen. nov. were often correctly identified at the generic level, i.e., we most often recognized that they were in the same genus. Because these slugs bear a large dorsal,

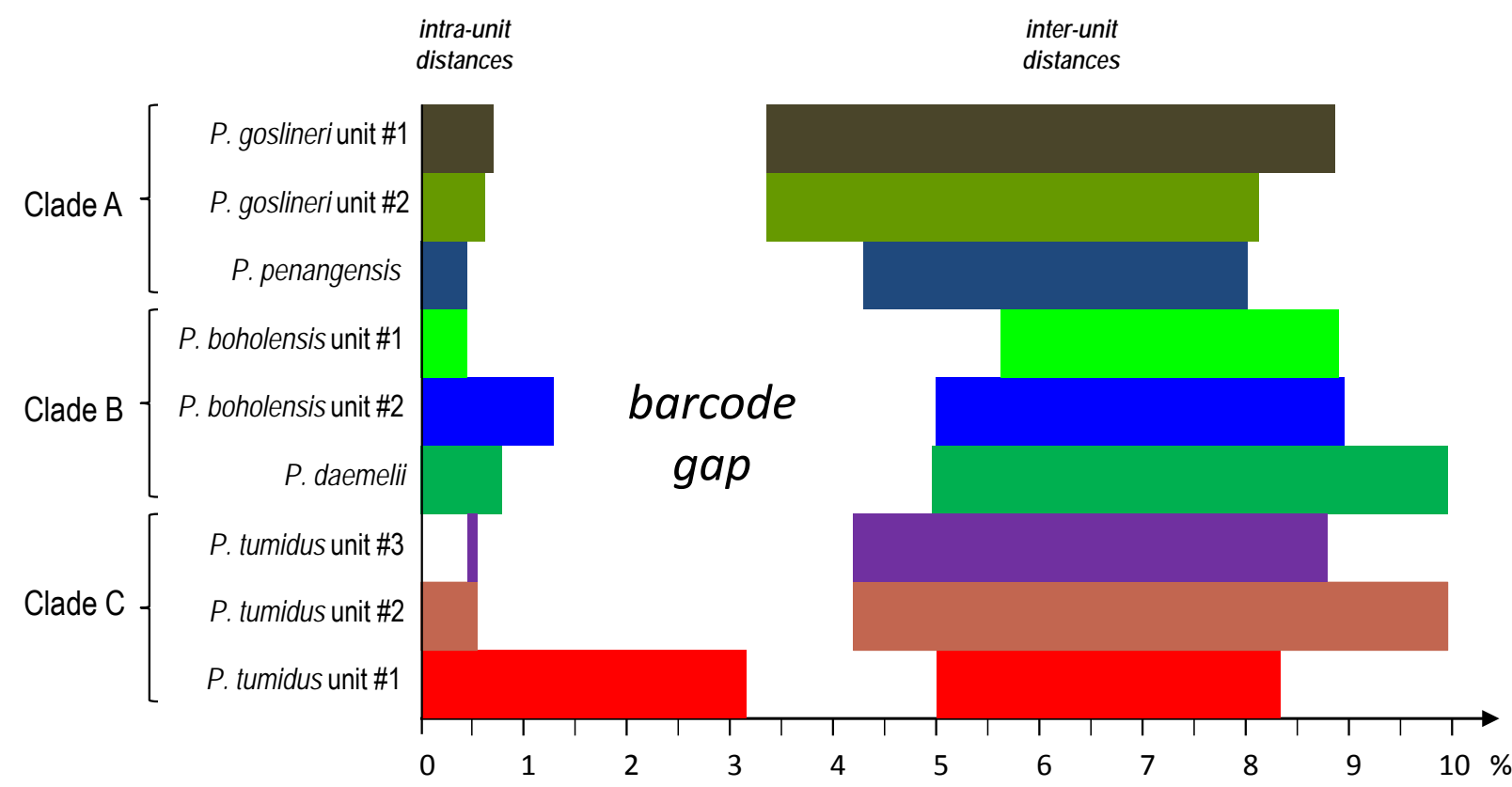

Fig. 5. Diagram that helps to visualize the data on pairwise genetic distances between COI sequences within and between mitochondrial units in Paromoionchis gen. nov. (see Table 3). Ranges of minimum to maximum distances are indicated (in percentages). For instance, within P. tumidus (Semper, 1880) unit\#1, individual sequences are between 0 and 3.2\% divergent; individual sequences between P. tumidus unit \#1 and the other units are minimally 5\% and maximally $8.4 \%$ divergent; overall, the distance gap between P. tumidus unit \#1 and the eight other units is between 3.2 and 5\%. The colors used for each unit are the same as those used in Figs 1-4 and 6. 
Table 3. Summary of internal traits that can help distinguish species of Paromoionchis gen. nov. All traits may be subject to individual variation. Traits are described in detail in the corresponding species descriptions and discussed in the species remarks. Traits are indicated for the mitochondrial units (when applicable) to show that those units are cryptic anatomically.

\begin{tabular}{|c|c|c|c|c|c|c|c|}
\hline Species & $\begin{array}{l}\text { Mitoch. } \\
\text { unit }\end{array}$ & $\begin{array}{c}\text { Clade } \\
\text { (Figs 1-4) }\end{array}$ & $\begin{array}{c}\text { Retractor } \\
\text { muscle (penis) } \\
\text { attachment site }\end{array}$ & $\begin{array}{l}\text { Accessory penial } \\
\text { gland \& spine } \\
\text { (size) }\end{array}$ & $\begin{array}{l}\text { Penis } \\
\text { shape }\end{array}$ & $\begin{array}{l}\text { Penis } \\
\text { hooks }\end{array}$ & Distribution \\
\hline \multirow{3}{*}{ P. tumidus } & $\# 1$ & $\mathrm{C}$ & $\sim$ heart & yes ( 1 to $2 \mathrm{~mm})$ & thin & $\begin{array}{c}\text { yes } \\
(<20 \mu \mathrm{m})\end{array}$ & $\begin{array}{c}\text { from Andaman Islands to Japan } \\
\text { and New South Wales }\end{array}$ \\
\hline & $\# 2$ & $\mathrm{C}$ & $\sim$ heart & yes $(1.2$ to $1.8 \mathrm{~mm})$ & thin & $\begin{array}{c}\text { yes } \\
(<22 \mu \mathrm{m})\end{array}$ & $\begin{array}{l}\text { Northern Territory, Sumatra, } \\
\text { Lombok, Luzon and Bohol }\end{array}$ \\
\hline & $\# 3$ & $\mathrm{C}$ & $\sim$ heart & yes $(0.8$ to $1 \mathrm{~mm})$ & thin & $\begin{array}{c}\text { yes } \\
(<28 \mu \mathrm{m})\end{array}$ & Papua New Guinea \\
\hline P. daemelii & - & B & $\begin{array}{l}\text { very short or } \\
\text { vestigial }\end{array}$ & yes $(2.5$ to $2.7 \mathrm{~mm})$ & thin & no & $\begin{array}{c}\text { New South Wales and } \\
\text { Queensland }\end{array}$ \\
\hline \multirow[b]{2}{*}{ P. boholensis } & $\# 1$ & $\mathrm{~B}$ & vestigial & yes ( 1 to $1.2 \mathrm{~mm})$ & thin & no & Bohol and Luzon \\
\hline & $\# 2$ & $\mathrm{~B}$ & none or vestigial & yes $(1.1$ to $1.8 \mathrm{~mm})$ & thin & no & $\begin{array}{c}\text { Ambon, Bali, Halmahera, Kei, } \\
\text { Seram and Sulawesi }\end{array}$ \\
\hline P. penangensis & - & A & strong and $\sim$ heart & no & large & no & from Western India to Malaysia \\
\hline \multirow[t]{2}{*}{ P. goslineri } & $\# 1$ & A & $\begin{array}{c}\text { thin }(\sim \text { central } \\
\text { nervous system }) \\
\text { or vestigial }\end{array}$ & no & thin & no & Luzon \\
\hline & $\# 2$ & A & long and $\sim$ heart & no & thin & no & $\begin{array}{l}\text { Ambon, Bali, Halmahera, } \\
\text { Sulawesi and Timor }\end{array}$ \\
\hline
\end{tabular}

central, retractable papilla that looks like a peduncle, we called them the 'peduncle' slugs in the field. This peduncle, however, is not fully reliable, because a similar structure is found in other genera; for instance, a similar peduncle is found in Wallaconchis buetschlii (Stantschinsky, 1907) (see Goulding et al. 2018c), and it often cannot be seen because it is fully retractable inside the notum. In the field, 'peduncle' slugs were numbered individually without any a priori species designation, because they all live in a similar habitat and are not distinct externally (their color patterns are similar and individual variation is high). Even though slugs in Paromoionchis gen. nov. are not distinct externally, they differ internally for characters from the male copulatory apparatus (Table 3).

Within clade A, P. penangensis gen. et sp. nov. and $P$. goslineri gen. et sp. nov. are distinct anatomically from each other and from all the slugs in clades B and C (Figs 1-4, Table 3): P. penangensis gen. et sp. nov. and $P$. goslineri gen. et sp. nov. lack an accessory penial gland, which is present in clades $\mathrm{B}$ (P. daemelii and P. boholensis gen. et sp. nov.) and C (P. tumidus mitochondrial units); also, P. penangensis gen. et sp. nov. is characterized by a large penis while $P$. goslineri gen. et sp. nov. is characterized by a thin penis. There is no anatomical difference between $P$. goslineri gen. et sp. nov. mitochondrial unit \#1 and unit \#2.

Within clade B, P. daemelii and P. boholensis gen. et sp. nov. are distinct anatomically from all the slugs in clades A and C (Figs 1-4, Table 3): P. daemelii and P. boholensis gen. et sp. nov. are characterized by an accessory penial gland, which is lacking in clade A ( $P$. penangensis gen. et sp. nov. and $P$. goslineri gen. et sp. nov.) and the penis of $P$. daemelii and $P$. boholensis gen. et sp. nov. bears no hooks, which are present in clade C (P. tumidus mitochondrial units). Also, P. daemelii and P. boholensis gen. et sp. nov. are anatomically distinct from each other: the spine of the accessory penial gland is longer in $P$. daemelii than in P. boholensis gen. et sp. nov. However, there is no anatomical difference between $P$. boholensis gen. et sp. nov. mitochondrial unit \#1 and unit \#2. 
DAYRAT B. et al., A new genus of mangrove onchidiid slugs

Within clade $\mathrm{C}$, the three mitochondrial units of $P$. tumidus are not anatomically distinct from each other, but they differ from all the slugs in clades B and C (Figs 1-4, Table 3): P. tumidus is characterized by an accessory penial gland, which is lacking in clade A (P. penangensis gen. et sp. nov. and $P$. goslineri gen. et sp. nov.); also, the penis of $P$. tumidus bears hooks which are lacking in clade B (P. daemelii and P. boholensis gen. et sp. nov.).

\section{Species delineation}

According to mitochondrial DNA sequences, there are nine least-inclusive, reciprocally monophyletic units (Figs 1-2, Table 3). Several of those units, however, cannot be distinguished anatomically: the three mitochondrial units of $P$. tumidus (units \#1, \#2 and \#3) are completely cryptic (externally and internally), as well as the two mitochondrial units of $P$. boholensis gen. et sp. nov. (units \#1 and \#2) and the two mitochondrial units of P. goslineri gen. et sp. nov. (units \#1 and \#2). Furthermore, nuclear DNA sequences show that there likely is gene flow between some of the mitochondrial units because they are not recovered as reciprocally monophyletic (Figs 3-4): in analyses based on nuclear sequences, individuals of $P$. tumidus units \#1, \#2 and \#3 are all mixed together, as well as those of P. boholensis gen. et sp. nov. units \#1 and \#2 and those of $P$. goslineri gen. et sp. nov. units \#1 and \#2.

Therefore, only five species of Paromoionchis are recognized here: P. boholensis gen. et sp. nov., $P$. daemelii, $P$. goslineri gen. et sp. nov., P. penangensis gen. et sp. nov. and P. tumidus. These five species are cryptic externally but are distinct anatomically: their male parts differ greatly (Table 3 ). Their monophyly is supported by both nuclear and mitochondrial sequences, with the exception of P. tumidus, recovered as unresolved branches in nuclear trees (Figs 1-4). The existence of least-inclusive mitochondrial units which are anatomically cryptic within P. tumidus (units \#1, \#2 and \#3), P. boholensis gen. et sp. nov. (units \#1 and \#2) and P. goslineri gen. et sp. nov. (units \#1 and \#2) can be explained with reference to the mode of inheritance of the mitochondrial genome and the complex geological history of the region, especially the many changes in sea levels (see Discussion).

\section{Systematics and anatomical descriptions}

Class Gastropoda Cuvier, 1795

Subclass Heterobranchia Burmeister, 1837

Order Systellomatophora Pilsbry, 1948

Superfamily Onchidioidea Rafinesque, 1815

Family Onchidiidae Rafinesque, 1815

Paromoionchis Dayrat \& Goulding gen. nov. urn:Isid:zoobank.org:act:4506A7F2-CC0B-4F23-8F5E-4DE2AA42B61F

\section{Type species}

Onchidium tumidum Semper, 1880, designated here.

\section{Diagnosis}

Body not flattened. No dorsal gills. Dorsal eyes present on notum. Retractable, central papilla (usually with four dorsal eyes) present, often raised above dorsal surface. Eyes at tip of short ocular tentacles. Male opening below right ocular tentacle and to its left. Foot wide. Pneumostome median, on ventral hyponotum. Intestinal loops of type II. Rectal gland absent. Accessory penial gland present or absent. When present, accessory penial gland with muscular sac. Penis with or without hooks. 


\section{Differential diagnosis}

No external diagnostic feature unambiguously distinguishes Paromoionchis gen. nov. from all other genera (which is not surprising because many onchidiid species from different genera are very similar externally). However, Paromoionchis gen. nov. is characterized by a unique combination of internal and external characters: no dorsal gills, male opening below and to the left of the right eye tentacle, no rectal gland and intestinal loops of type II (see Labbé 1934a: 177, fig. 3, for a comparison of digestive types). According to our data, any onchidiid slug with this combination of characters must belong to a species of Paromoionchis gen. nov.

\section{Etymology}

The name Paromoionchis is a combination of parómoios ( $\pi \alpha \rho$ ó $\mu о \imath \varsigma)$, which means 'similar' in Greek (because members look very similar externally) and onchis, a word derived from the Greek onchos (o ӧүко૬) and one of the early names used to refer to onchidiid slugs.

\section{Gender}

Masculine, the gender of onchis (ICZN Art. 30.1.1), a word derived from the masculine Greek word o

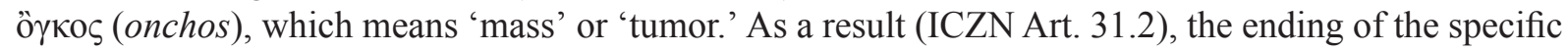
name tumidum (a Latin adjective) must be changed from neuter (because Onchidium is a name of neuter gender) to masculine (tumidus).

\section{Distribution}

The new genus described here is distributed from the western coast of India in the west, all the way to the subtropical waters of Japan $\left(\sim 33^{\circ} \mathrm{N}\right)$, Papua New Guinea and the subtropical waters of southeastern Australia $\left(\sim 32^{\circ} \mathrm{S}\right)$ in the east (Fig. 6). We did not find Paromoionchis gen. nov. in South Africa, Madagascar or Mauritius, but it is possible that it is present in areas east of Papua New Guinea, such as Fiji and New Caledonia, where we did not collect.

\section{Habitat}

The five known species of Paromoionchis gen. nov. primarily live on mud, in or next to mangroves, which explains why three species have just been discovered now, because the mangroves of SouthEast Asia have been very poorly explored. Occasionally, these slugs can also be found in or on muddy logs, coral rubble, sandy mud or even sand with very little mud in it. Paromoionchis tumidus, which is widespread and very common, can be found in nearly all these habitats, even though the mud surface remains where it is most commonly found, like all other species of the genus. Because members of Paromoionchis gen. nov. prefer the mud surface, live animals are often covered with mud.

\section{Remarks}

A new generic name is needed because no existing name applies to the clade described here. Our remarks are based on the examination of all the type specimens available, especially those of the type species of all genera, the careful analyses of all the original descriptions (especially when no type specimens were available), and our ongoing taxonomic revision of each genus of the family. Three existing generic names are junior synonyms of Onchidella J.E. Gray, 1850, which is not found in the tropical Indo-West Pacific and is characterized by a completely different anatomy (Dayrat 2009; Dayrat et al. 2011b). Seven generic names apply to the clade including all the onchidiid slugs with dorsal gills, i.e., Peronia Fleming, 1822 (Dayrat 2009). Labella Starobogatov, 1976 is a junior synonym of Onchidium Buchannan, 1800, which applies to a distinct clade including three species (Dayrat et al. 2016). Paraoncidium Labbé, 1934 is a junior synonym of Onchidina Semper, 1882, which applies to a 
distinct monotypic genus from southeastern Australia (Dayrat \& Goulding 2017). Peronina Plate, 1893 applies to a clade including slugs characterized by a pneumostome located at the margin between the dorsal notum and the ventral hyponotum. Platevindex Baker, 1938 applies to a clade including species with a distinctly flattened body and a narrow foot. Semperoncis Starobogatov, 1976 applies to species characterized by a very different anatomy and which are adapted to terrestrial life in the Philippines (Dayrat 2010). And, finally, Melayonchis Dayrat \& Goulding, 2017 applies to a distinct clade including slugs with a different anatomy (Dayrat et al. 2017).

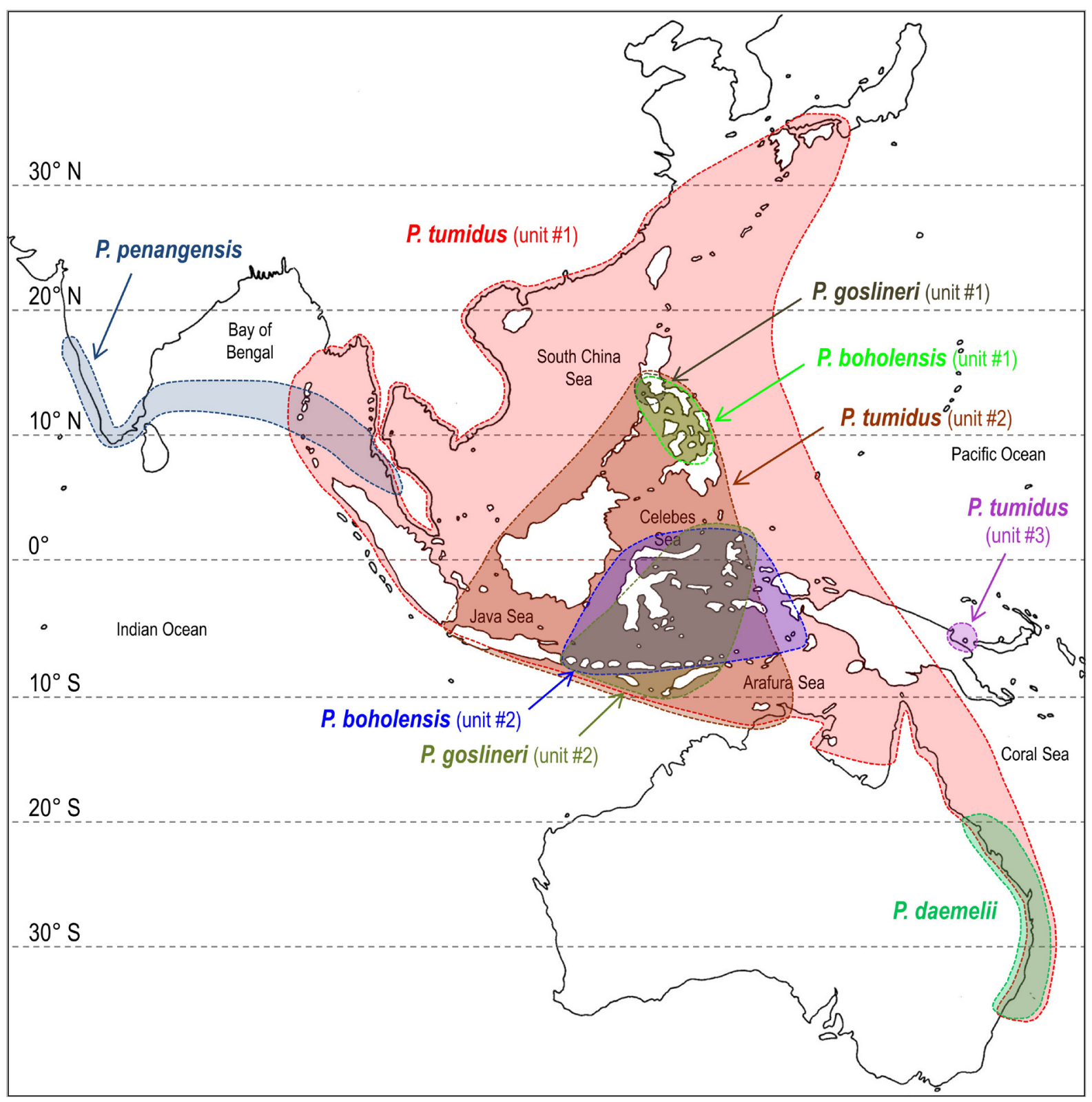

Fig. 6. Geographic distribution of the five species of Paromoionchis gen. nov. Distinct colors are used for each mitochondrial unit found in P. tumidus (Semper, 1880) comb. nov., P. boholensis gen. et sp. nov. and $P$. goslineri gen. et sp. nov., and the colors used for each unit are the same as those used in Figs 1-5. Colored areas correspond to hypothetical ranges proposed based on known records (all of which are new here except for the type localities of P. tumidus and P. daemelii (Semper, 1880) comb. nov.). 
Paromoionchis tumidus (Semper, 1880) comb. nov.

Figs 7-25

Onchidium tumidum Semper, 1880: 262-263, pl. 20, figs 3-4, pl. 23, fig. 4.

Onchidium samarense Semper, 1880: 268-269, pl. 20, figs 9, 13, pl. 23, fig. 7. Syn. nov.

Onchidium mertoni Simroth, 1918: 294-296, pl. XX, figs 43-47. Syn. nov.

Onchidium hongkongense Britton, 1984: 188-190, figs 6-7. Syn. nov.

Onchidium samarense - Semper 1882: 268-269, pl. 21, fig. 5.

\section{Material examined}

Type material

SINGAPORE • lectotype (here designated; 28/22 mm); ZMB 39019a • 15 paralectotypes; ZMB 39019b

- 2 paralectotypes; NHMD $300305 \bullet 1$ paralectotype; SMF 333603/1.

AUSTRALIA • 2 paralectotypes; Queensland, Mackay; ZMB 39020.

\section{Other type material}

PHILIPPINES • lectotype of Onchidium samarense (here designated; 22/17 mm); Samar Island, Palapa harbor; ZMB $39025 \mathrm{a} \cdot 2$ paralectotypes of $O$. samarense $(24 / 20$ and $20 / 15 \mathrm{~mm})$; same locality as lectotype; ZMB 39025b.

INDONESIA - lectotype of Onchidium mertoni (here designated; 15/9 mm); Aru Islands, Kobroor, Sungai; 5 Jan. 1908; ZMB 121591a 4 paralectotypes of $O$. mertoni $(14 / 8,14 / 10,15 / 14$ and 14/10 mm); same data as for lectotype; ZMB $121591 \mathrm{~b}$.

CHINA • holotype of Onchidium hongkongense (17/13 mm); Hong Kong; NHM 1982290 • 15 paratypes; same locality as holotype; NHM 1982291 to 1982292.

\section{Notes on type material}

Onchidium tumidum. Lectotype, 28/22 mm, designated here (ZMB 39019a). All other syntypes become paralectotypes (the 15 paralectotypes from the same lot are now ZMB 39019b). According to the original description, the type material included 42 specimens from Singapore and an unknown number of specimens from Port Mackay, Queensland, Australia. A total of 21 syntypes were located in museum collections: 19 specimens from Singapore (16 specimens, ZMB 39019; 2 specimens, NHMD 300305; 1 specimen, SMF 333603/1) and 2 specimens from Mackay (ZMB 39020). There also are two possible syntypes from Australia (ZMH 27480/2). Two similar species of Paromoionchis gen. nov. are found at Port Mackay, P. tumidus and $P$. daemelii, which anatomically can only be distinguished based on the insertion of the retractor muscle of the penis. In the lectotype designated here from Singapore, the retractor muscle inserts near the heart, exactly as in the species described here. However, in one of the two paralectotypes of P. tumidus from Mackay (ZMB 39020), the retractor muscle is vestigial, as in $P$. daemelii (in the other paralectotype from Mackay, the male apparatus was destroyed prior to the present investigation and could not be examined). Hence, it was necessary to designate a lectotype from Singapore in order to clarify the application of $P$. tumidus. Note that the type material was fixed in formalin more than 130 years ago and no DNA sequencing could be attempted.

Onchidium samarense. Lectotype, 22/17 mm, designated here (ZMB 39025a). The two other syntypes become paralectotypes (ZMB 39025b). According to the original description, the type material included only two specimens from the same locality in Samar, Philippines. However, the jar with the type material currently contains three similar-looking specimens (syntypes), all of which were dissected prior to the present study. It is not excluded that the original description was based on only two of those three 
specimens but it is also possible that Semper himself identified all three specimens as $O$. samerense [sic] (with a minor typo in the original description). The lectotype still contains all its internal organs, including the male copulatory parts. One paralectotype $(24 / 20 \mathrm{~mm})$ is mostly destroyed, with no internal organs left except the digestive gland (a few destroyed pieces of organs are in a vial). The other paralectotype $(20 / 15 \mathrm{~mm})$ still contains internal organs, but the male parts are missing. Our observations and comments are mostly based on the only specimen with male parts; hence its designation as a lectotype. Note that the type material was fixed in formalin more than 130 years ago and no DNA sequencing could be attempted. Note also that if, in the future, Onchidium samarense were to be regarded as a valid species name in Paromoionchis gen. nov., the specific name samarense (neuter) would need to become samarensis (masculine).

Onchidium mertoni. Lectotype, $15 / 9 \mathrm{~mm}$, designated here (ZMB 121591a). The four other syntypes become paralectotypes (ZMB 121591b). Simroth mentioned in the original description that all five specimens were very hard. Indeed, it seems that they dried out at some point and they are very poorly preserved. The lectotype designated here is the only specimen that is complete. It was partially dissected for the present study (the penial hooks, identical to those of $O$. tumidum, are illustrated here). Two paralectotypes $(14 / 8$ and $14 / 10 \mathrm{~mm})$ were dissected prior to the present study and are completely empty. Two other paralectotypes (15/14 and $14 / 10 \mathrm{~mm}$ ) are in very poor condition (the body is extremely hard and the digestive system is partly outside the body through the foot). A lectotype is designated here to clarify the application of the name $O$. mertoni because several species of Paromoionchis gen. nov. are potentially sympatric in the Aru Islands and so it cannot be excluded that the five original syntypes belong to different species. Note that the type material was fixed in formalin more than 100 years ago and no DNA sequencing could be attempted.

Onchidium hongkongense. Holotype, $17 / 13 \mathrm{~mm}$, by original designation (NHM 1982290) and 15 paratypes (NHM 1982291, NHM 1982292). The holotype is largely destroyed due to prior dissection, likely by Britton. Large parts of the notum and of the reproductive organs are missing. Even though it is mostly destroyed, the digestive system is confirmed to be of type II. A few paratypes were checked for the present study and their anatomy matches that of the holotype. Note that the type material was fixed in formalin more than 40 years ago and no DNA sequencing could be attempted. Note also that the specific name hongkongensis (masculine or feminine gender) originally used by Britton is corrected to hongkongense (neuter) for gender agreement with Onchidium. Should Onchidium hongkongense ever become a valid species name in Paromoionchis gen. nov., hongkongense would then need to be changed back to hongkongensis.

\section{Other material}

AUSTRALIA - New South Wales • 1 spec. (20/15 [1522] mm); Sydney, Pittwater, Careel Bay; $33^{\circ} 37.323^{\prime} \mathrm{S}, 151^{\circ} 19.878^{\prime}$ E; 24 Nov. 2011; station 40; supratidal zone on margin of salt marsh, mangrove patch on side of creek; AM C.468918.005 - 1 spec. (35/20 [1529] mm); Sydney, Hawkesbury River, Cheero Point; $33^{\circ} 30.687^{\prime} \mathrm{S}, 151^{\circ} 11.669^{\prime} \mathrm{E}$; 25 Nov. 2011; station 42; open mangrove with old logs; AM C.468924.001 - 1 spec. (33/20 [1528] mm); same data as for preceding; AM C.468923.002 - 1 spec. (32/20 [1530] mm); same data as for preceding; AM C.468925.001. - Northern Territory • 1 spec. (45/32 [1634] mm); Darwin, near Channel Island Road; 12³4.979’ S, 130 55.992’ E; 16 Aug. 2012; station 65; sequence of Sonneratia, Rhizophora and Ceriops; NTM P.57620 • 1 spec. (40/25 [1686] mm); Darwin, end of Channel Island Road; 12³3.557' S, 130 52.894’ E; 17 Aug. 2012; station 66; sequence of Sonneratia, Rhizophora and Ceriops; NTM P.57621 1 spec. (42/38 [1638] mm); same data as for preceding; NTM P.57623 2 spec. (30/17 [1705] and 17/12 [1645] mm); Darwin, close to Tiger Brenan Road (small service road); 12²8.782’ S, 130 54.750’ E; 19 Aug. 2012; station 69; high tidal Ceriops; NTM P.57622 - 1 spec. (36/22 [1651] mm); Darwin, Elizabeth Road; $12^{\circ} 32.893^{\prime}$ S, $130^{\circ} 57.642^{\prime}$ E; 20 Aug. 2012; station 70; Ceriops and old logs in Rhizophora forest; NTM P.57624. 
- Queensland • 1 spec. (45/30 [2562] mm); Cairns, Yorkey's Knob; $16^{\circ} 48.558^{\prime} \mathrm{S}, 145^{\circ} 42.768^{\prime} \mathrm{E}$; 17 Jun. 2013; station 101; hard, red mud with grasses; MTQ 11 spec. (45/30 [2602] mm); Townsville, Magnetic Island; $19^{\circ} 09.938^{\prime} \mathrm{S}, 146^{\circ} 49.029^{\prime} \mathrm{E}$; 24 Jun. 2013; station 109; water on the mud; MTQ - 1 spec. (15/10 [2627] mm); Bowen; 2000.658' S, 148 $15.878^{\prime}$ E; 1 Jul. 2013; station 115; back of mangrove across from beach, dense Rhizophora, Avicennia trees with soft mud around; MTQ • 1 spec. (55/30 [2637] mm); Bowen; 2000.913’ S, 148 $15.745^{\prime}$ E; 1 Jul. 2013; station 116; mangrove away from ocean, small area of open Avicennia mangrove, surrounded by Rhizophora; MTQ 1 spec. (20/10 [2652] mm); Bowen, Doughty Creek; 2001.264' S, 148¹4.345’ E; 2 Jul. 2013; station 117; narrow Avicennia and Rhizophora mangrove, by creek, some muddy areas and some very sandy; MTQ • 1 spec. (35/20 [2657] mm); Bowen; 2001.478' S, 148¹4.224' E; 3 Jul. 2013; station 119; Rhizophora and Avicennia mangrove; MTQ • 1 spec. (30/20 [2701] mm); Mackay; 20 08.511' S, 149 $12.076^{\prime} \mathrm{E}$; 8 Jul. 2013; station 125; large, dense and sandy mangrove and, by side of river, small strip of mud with Avicennia and Rhizophora; MTQ 1 spec. $(30 / 25$ [1531] mm); Thirsty Sound, Plum Tree, beach in front of Endeavour Park; $22^{\circ} 08.144^{\prime}$ S, $150^{\circ} 01.856^{\prime}$ E; 14 Sep. 2002; I. Loch, D.L. Beechey and A.C. Miller leg.; sheltered, muddy cobble shore; AM C.575588.

BRUNEI DARUSSALAM • 3 spec. (55/30 [1036], 35/20 [1035] and 20/15 [1062] mm); Pulau Pyatan,

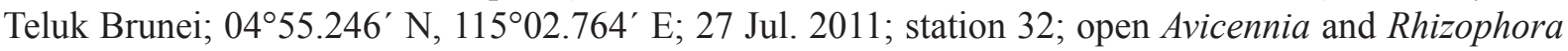
mangrove, with hard mud; BDMNH.

INDIA • 1 spec. (26/17 [1119] mm); Andaman Islands, Middle Andaman, Shantipur, Kadamtala; $12^{\circ} 19.843^{\prime} \mathrm{N}, 092^{\circ} 46.377^{\prime} \mathrm{E}$; 12 Jan. 2011; station 58; open area with hard mud and many old logs, next to a mangrove with medium trees; BNHS 88.

INDONESIA - Sumatra • 1 spec. (24/15 [1732] mm); Kualapenet; $05^{\circ} 16.275^{\prime} \mathrm{S}, 105^{\circ} 51.287^{\prime}$ E; 17 Oct. 2012; station 77; narrow band of mangrove between ocean and fish ponds; UMIZ 00121 2 spec. (35/20 [1754] and 26/16 [1755] mm); Bakauheni; 0550.560' S, 105 46.200' E; 21 Oct. 2012; station 81; small mangrove, not far from road and next to large harbor, very impacted mangrove; UMIZ 00122 - 1 spec. (38/30 [1794] mm); same data as for preceding; UMIZ 00138 • 1 spec. (20/12 [1798] mm); $\mathrm{S}$ of Bandar Lampung; $05^{\circ} 32.66^{\prime} \mathrm{S}, 105^{\circ} 15.113^{\prime} \mathrm{E}$; 28 Oct. 2012; station 83; high intertidal, fairly dense roots with some Avicennia and Nypa, edge of mangrove by road; UMIZ 00123. - Sulawesi 2 spec. (25/15 [2200] and 20/12 [2201] mm); Tamperong; 01 ${ }^{\circ} 41.513^{\prime} \mathrm{N}, 1^{\circ} 05^{\circ} 00.797^{\prime} \mathrm{E}$; 12 Mar. 2013; station 87; muddy mangrove with small Rhizophora in dense patches; UMIZ 00124 - 1 spec. $(27 / 15$ [2240] mm); Sondaken; $01^{\circ} 21.777^{\prime} \mathrm{N}, 1^{2} 4^{\circ} 32.594^{\prime} \mathrm{E}$; 13 Mar. 2013; station 89; sand, small rocks, pieces of wood outside narrow coastal mangrove of mostly Rhizophora; UMIZ 00125 • 1 spec. (30/20

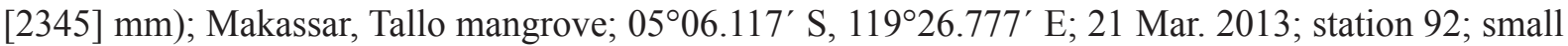
mangrove used as outhouse by village, very impacted with trash; UMIZ 00126 • 1 spec. (20/13 [2355] mm); Barru; $04^{\circ} 25.437^{\prime}$ S, $119^{\circ} 35.953^{\prime}$ E; 22 Mar. 2013; station 93; forest of mostly Avicennia and Rhizophora, with hard and sandy mud; UMIZ 00127. - Ambon - 1 spec. (25/15 [3541] mm); Lateri; $03^{\circ} 38.261^{\prime} \mathrm{S}, 128^{\circ} 14.716^{\prime} \mathrm{E}$; $12 \mathrm{Feb}$. 2014; station 128; mudflat next to small creek in low intertidal of mangrove preserve; UMIZ 00128 • 3 spec. (45/30 [2832], 22/12 [2839] and 35/22 [2840] mm); Lateri; $03^{\circ} 38.237^{\prime} \mathrm{S}, 128^{\circ} 14.783^{\prime} \mathrm{E}$; $14 \mathrm{Feb}$. 2014; station 131; muddy mangrove with Rhizophora; UMIZ 00129. - Seram • 2 spec. (20/15 [2874] and 30/15 [2875] mm); Kawa; 02 58.240’ S, 128 $07.066^{\prime}$ E; 18 Feb. 2014; station 135; mud next to a seawall adjacent to a mangrove; UMIZ 00130. - Lombok • 2 spec. (30/20 [2950] and 20/12 [2952] mm); Tanjung Batu village; 08 ${ }^{\circ} 45.748^{\prime} \mathrm{S}, 116^{\circ} 02.892^{\prime} \mathrm{E}$; 24 Mar. 2014; station 145; Avicennia forest; UMIZ 00131 • 1 spec. (20/14 [2961] mm); Seriwe Bay; 08 51.960' S, $116^{\circ} 32.838^{\prime}$ E; 25 Mar. 2014; station 146; Avicennia mangrove with hard mud and rocks; UMIZ 00132 - 1 spec. (18/10 [2960] mm); same data as for preceding; UMIZ 00139. - Bali • 1 spec. (25/14 [3051] $\mathrm{mm}$ ); Denpasar; $08^{\circ} 47.435^{\prime} \mathrm{S}, 115^{\circ} 13.197^{\prime} \mathrm{E}$; 1 Apr. 2014; station 153 ; large mangrove by road, very soft mud; UMIZ $00133 \cdot 1$ spec. (30/20 [3070] mm); Denpasar; $08^{\circ} 46.126^{\prime} \mathrm{S}, 115^{\circ} 10.803^{\prime} \mathrm{E}$; 
DAYRAT B. et al., A new genus of mangrove onchidiid slugs

2 Apr. 2014; station 154; large mangrove by road, with shallow mud; UMIZ 00134. - Halmahera • 1 spec. (25/15 [5082] mm); Akelamo; 01 ${ }^{\circ} 01.329^{\prime} \mathrm{N}, 1^{2} 7^{\circ} 39.091^{\prime}$ E; 10 Mar. 2015; station 207; sandymuddy beach at margin of mangrove near village; UMIZ 00135 2 spec. (50/35 [5102] and 55/35 [5103] mm); Buli; $00^{\circ} 55.446^{\prime} \mathrm{N}, 128^{\circ} 20.612^{\prime} \mathrm{E}$; 16 Mar. 2015; station 212; logged area in front of old Rhizophora forest, by the road; UMIZ $00136 \cdot 1 \mathrm{spec}$. (55/30 [5042] mm); Buli; $00^{\circ} 55.367^{\prime} \mathrm{N}$, $128^{\circ} 20.647^{\prime}$ E; 17 Mar. 2015; station 213; tall and old Rhizophora forests, high intertidal; UMIZ 00137.

JAPAN • 1 spec. (22/10 [3761] mm); Ehime Prefecture, Misho Bay; 32 $57.634^{\prime}$ N, $132^{\circ} 33.205^{\prime}$ E; 4 Aug. 2014; station o28; mudflats; NSMT Mo 78984.

MALAYSIA - 1 spec. (40/25 [963] mm); Peninsular Malaysia, Nibong Tebal, Pulau Burung; $05^{\circ} 12.488^{\prime} \mathrm{N}, 100^{\circ} 25.564^{\prime} \mathrm{E}$; $11 \mathrm{Jul}$. 2011; station 17; soft mud, open mangrove of Rhizophora, with a few Sonneratia; USMMC 00057 - 1 spec. (18/12 [928] mm); E Peninsular Malaysia, Balok; $03^{\circ} 53.219^{\prime} \mathrm{N}, 103^{\circ} 21.978^{\prime}$ E; 14 Jul. 2011; station 19; mostly Rhizophora, with some Avicennia, hard mud with shallow pools, patches of soft mud; USMMC 00058.

PAPUA NEW GUINEA • 1 spec. (18/14 [5432] mm); Madang, Meiro River, near airport; $05^{\circ} 12.2^{\prime} \mathrm{S}$, 14547.4' E; 5 Nov. 2012; MNHN expedition Papua Niugini leg.; station PM01; Nypa palm swamp; MNHN IM-2013-10478 1 spec. (17/12 [5433] mm); same data as for preceding; MNHN IM-201310479.

PHILIPPINES - Luzon • 1 spec. (26/18 [3610] mm); Lian, Batangas; $13^{\circ} 58.130^{\prime} \mathrm{N}, 120^{\circ} 37.471^{\prime} \mathrm{E}$; 5 Jul. 2014; station 179; narrow and impacted mangrove of Avicennia near village, very sandy, little to no mud; PNM 041261 - 2 spec. (30/20 [3171] and 25/15 [3192] mm); Nasugbu, Batangas; $14^{\circ} 10.714^{\prime} \mathrm{N}$, $120^{\circ} 36.817^{\prime}$ E; 6 Jul. 2014; station 182; near village, well-preserved and dense forest of Avicennia and Rhizophora; PNM 041255 - 1 spec. (22/14 [3172] mm); same data as for preceding; PNM 041262 • 2 spec. (30/20 [3200] and 35/22 [3205] mm); Calantagan, Batangas; $13^{\circ} 55.319^{\prime} \mathrm{N}, 120^{\circ} 37.260^{\prime} \mathrm{E} ; 7 \mathrm{Jul}$. 2014; station 183; rocks next to Avicennia and Rhizophora forest; PNM 041256 • 1 spec. (30/18 [3202] $\mathrm{mm}$ ); same data as for preceding; PNM $041263 \bullet 1$ spec. (35/22 [3222] mm); Calantagan, Batangas; $13^{\circ} 53.278^{\prime} \mathrm{N}, 120^{\circ} 37.124^{\prime} \mathrm{E}$; 8 Jul. 2014; station 184; narrow forest on the shore, Avicennia and young Rhizophora; PNM 041257 • 1 spec. (33/15 [3229] mm); same data as for preceding; PNM 041264 •

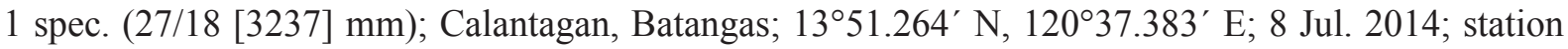
185; next to village, impacted, narrow Avicennia mangrove by the shore; PNM 041265. - Bohol 1 spec. (40/25 [3344] mm); Mabini; 0951.532' N, 124³1.685' E; 17 Jul. 2014; station 194; narrow mangrove on edge of fish ponds, tall Rhizophora and Avicennia trees, many old logs; PNM 041258 • 1 spec. (26/15 [3371] mm); Mabini; 0951.586’ N, 12434.155’ E; 18 Jul. 2014; station 196; Avicennia and Sonneratia open forest with sand, algae and coral rubble; PNM 041259 • $1 \mathrm{spec}$. (30/18 [3416] mm); Maribojoc; $09^{\circ} 44.280^{\prime} \mathrm{N}, 123^{\circ} 49.389^{\prime} \mathrm{E}$; 20 Jul. 2014; station 202; uplifted coral rubble with sand and algae, near Sonneratia trees; PNM 041260.

VIETNAM • 2 spec. (45/30 [5619] and 40/30 [5682] mm); Nha Trang; $12^{\circ} 12.778^{\prime} \mathrm{N}, 1^{\circ} 09^{\circ} 09.572^{\prime} \mathrm{E}$; 27 Jul. 2015; station 237; small strip of mud with a few Rhizophora trees next to a small river, by fish ponds and houses; ITBZC IM $00019 \cdot 1$ spec. (25/15 [5642] mm); Nha Trang; $12^{\circ} 24.168^{\prime} \mathrm{N}$, $109^{\circ} 10.058^{\prime}$ E; 29 Jul. 2015; station 239; mostly Avicennia and some small Rhizophora, with shallow mud; ITBZC IM 00020.

\section{Color and morphology of live animals (Figs 7-10)}

Live animals of units \#1 and \#2 are often abundantly covered with mud, in which case their dorsal color can hardly be seen. The background of the dorsal notum is brown, light to dark. That background can be homogenous or clearly mottled with darker or lighter areas and, occasionally, also with red areas. 

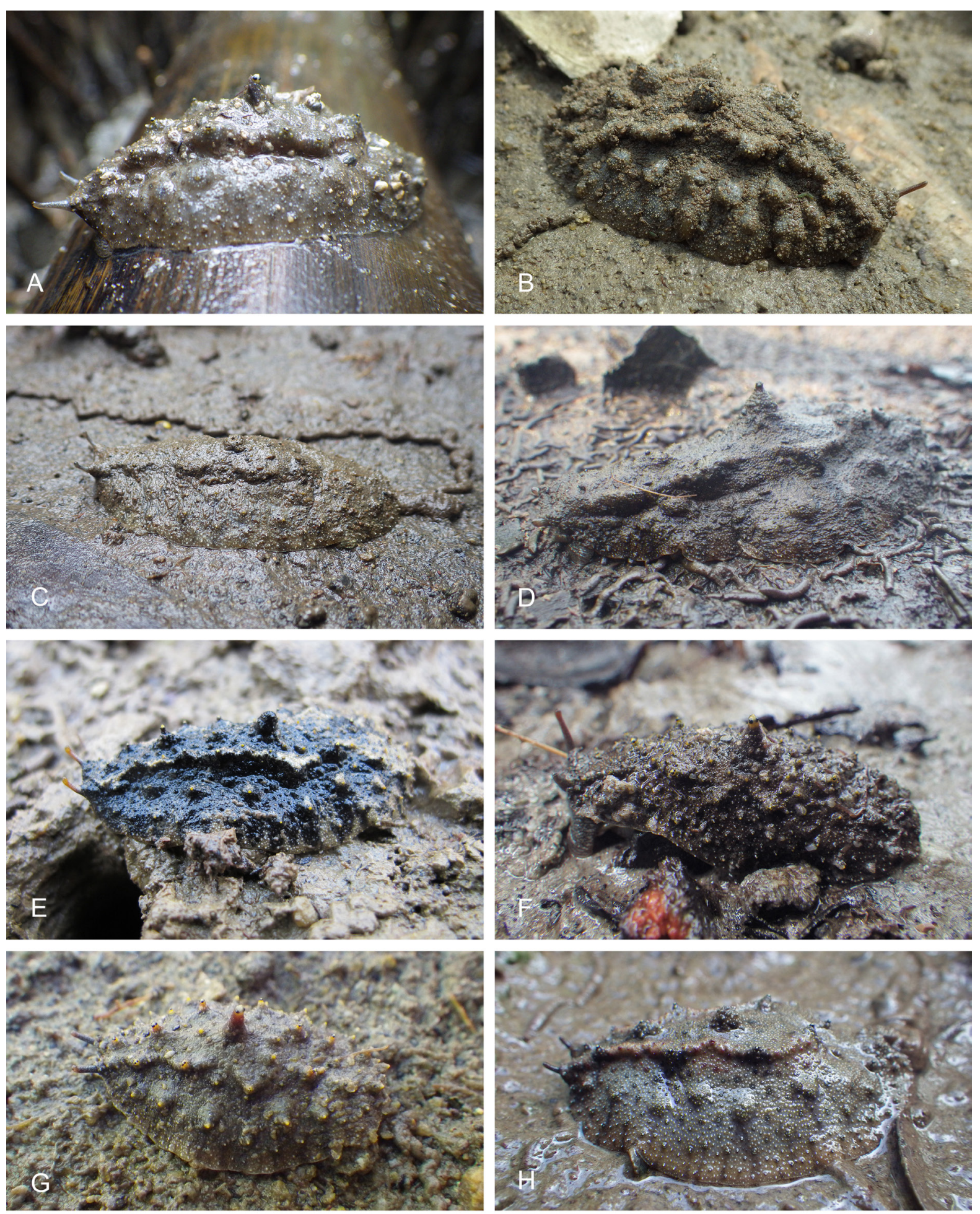

Fig. 7. Paromoionchis tumidus (Semper, 1880) comb. nov. unit \#1, live animals. A. Dorsal view, $35 \mathrm{~mm}$ long [3205], Philippines, Luzon (PNM 041256). B. Dorsal view, $40 \mathrm{~mm}$ long [5682], Vietnam (ITBZC IM 00019). C. Dorsal view, 33 mm long [3222], Philippines, Luzon (PNM 041257). D. Dorsal view, $54 \mathrm{~mm}$ long [5042], Indonesia, Halmahera (UMIZ 00137). E. Dorsal view, $30 \mathrm{~mm}$ long [1705], Australia, Northern Territory (NTM P.57622). F. Dorsal view, $26 \mathrm{~mm}$ long [2875], Indonesia, Seram (UMIZ 00130). G. Dorsal view, $17 \mathrm{~mm}$ long [2627], Australia, Queensland (MTQ). H. Dorsal view, $27 \mathrm{~mm}$ long [1755], Indonesia, Sumatra (UMIZ 00122). 

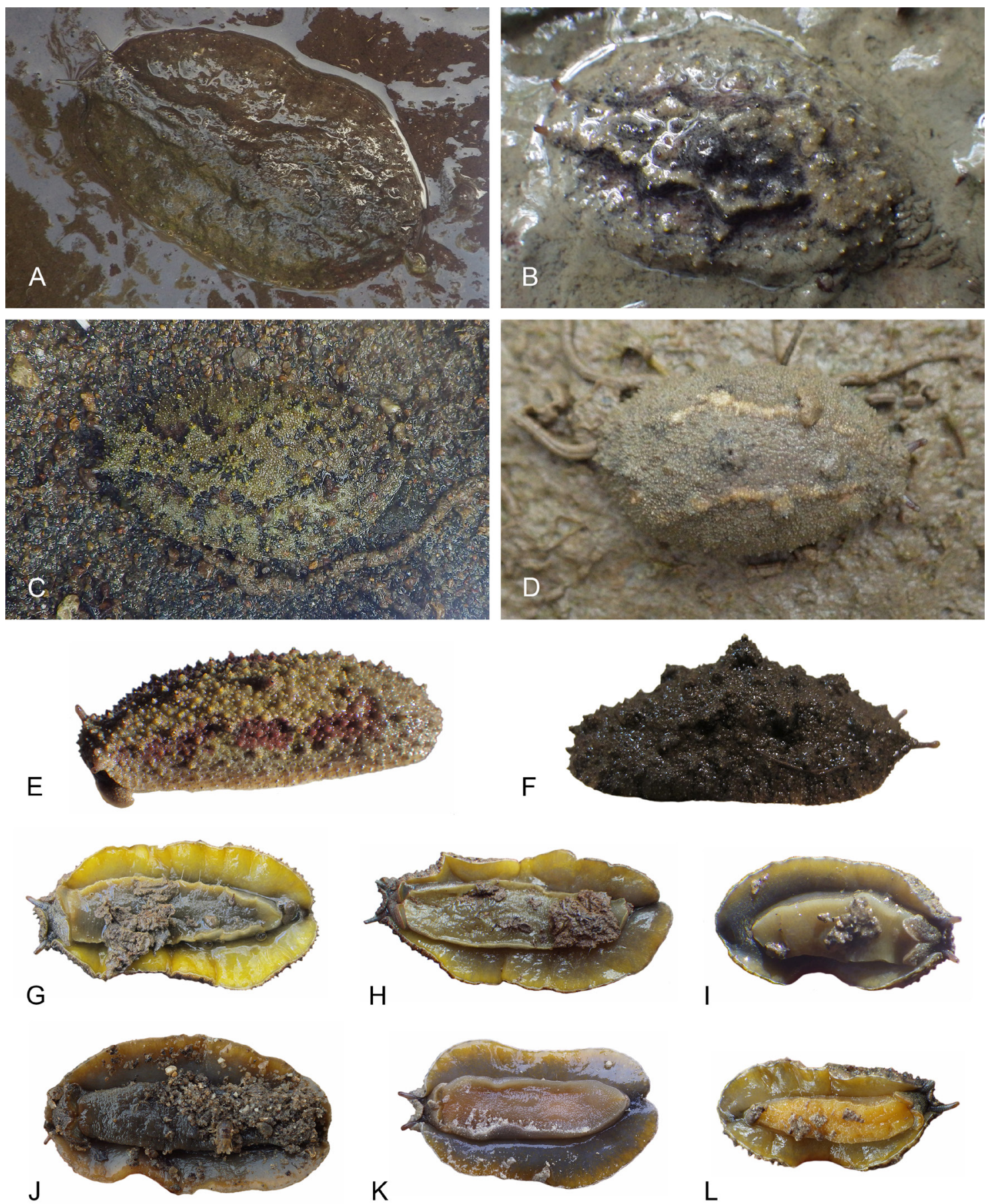

$\mathrm{L}$

Fig. 8. Paromoionchis tumidus (Semper, 1880) comb. nov. unit \#1, live animals. A. Dorsal view, $55 \mathrm{~mm}$ long [5103], Indonesia, Halmahera (UMIZ 00136). B. Dorsal view, $22 \mathrm{~mm}$ long [1732], Indonesia, Sumatra (UMIZ 00121). C. Dorsal view, $22 \mathrm{~mm}$ long [5082], Indonesia, Halmahera (UMIZ 00135). D. Dorsal view, $22 \mathrm{~mm}$ long [5642], Vietnam (ITBZC IM 00020). E. Dorsal view, $45 \mathrm{~mm}$ long [2657], Australia, Queensland (MTQ). F. Dorsal view, $31 \mathrm{~mm}$ long [1522], Australia, New South Wales (AM C.468918.005). G. Ventral view, $42 \mathrm{~mm}$ long [1686], Australia, Northern Territory (NTM P.57621). H. Ventral view, $47 \mathrm{~mm}$ long [2562], Australia, Queensland (MTQ). I. Ventral view, $19 \mathrm{~mm}$ long [2961], Indonesia, Lombok (UMIZ 00132). J. Ventral view, $44 \mathrm{~mm}$ long [5619], Vietnam (ITBZC IM 00019). K. Ventral view, 33 mm long [3416], Philippines, Bohol (PNM 041260). L. Ventral view, 24 mm long [3371], Philippines, Bohol (PNM 041259). 

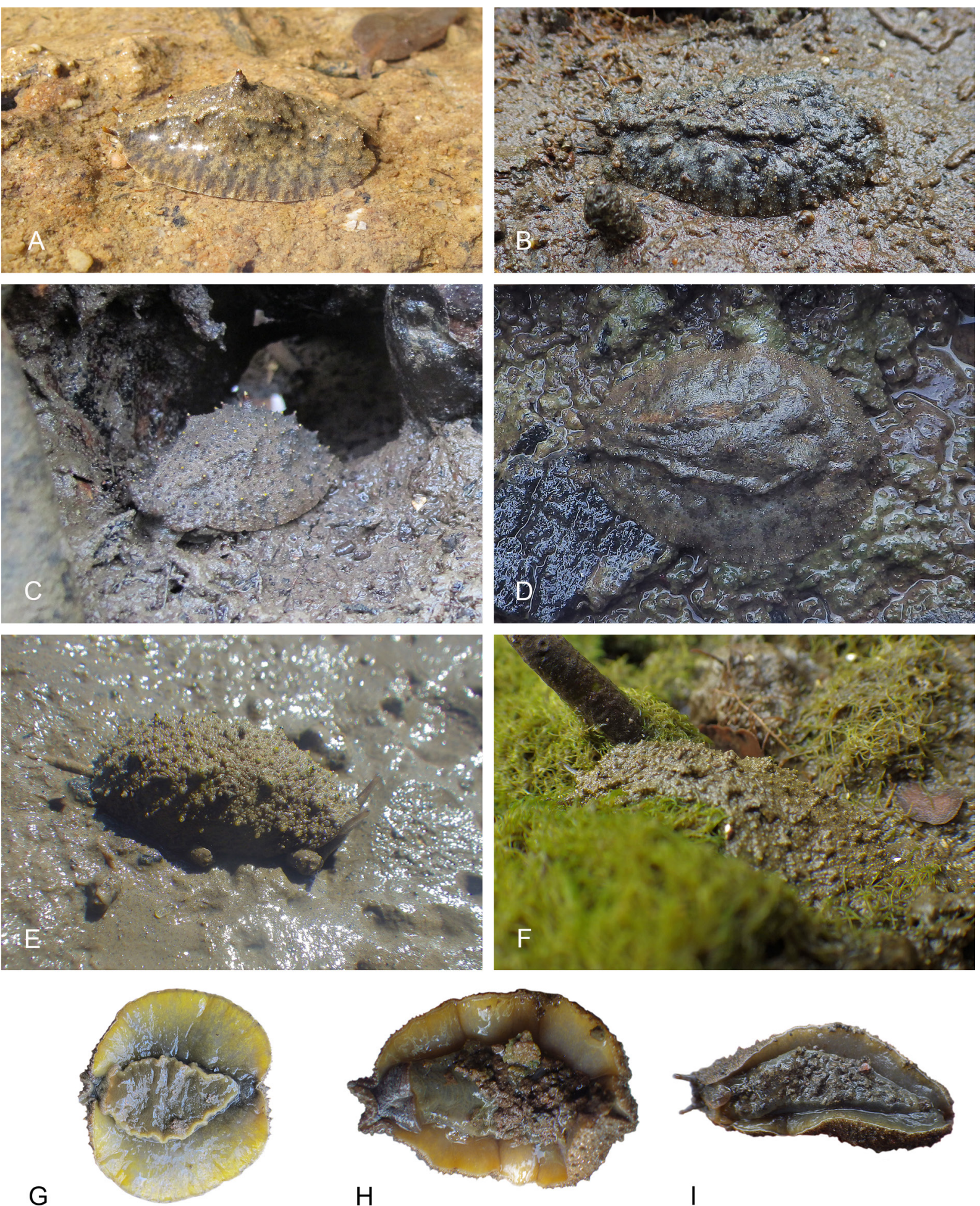

Fig. 9. Paromoionchis tumidus (Semper, 1880) comb. nov. unit \#2, live animals. A. Dorsal view, $38 \mathrm{~mm}$ long [1651], Australia, Northern Territory (NTM P.57624). B. Dorsal view, $32 \mathrm{~mm}$ long [3237], Philippines, Luzon (PNM 041265). C. Dorsal view, 45 mm long [1638], Australia, Northern Territory (NTM P.57623). D. Dorsal view, $43 \mathrm{~mm}$ long [1794], Indonesia, Sumatra (UMIZ 00138). E. Dorsal view, $17 \mathrm{~mm}$ long [2960], Indonesia, Lombok (UMIZ 00139). F. Dorsal view, $27 \mathrm{~mm}$ long [3610], Philippines, Luzon (PNM 041261). G. Ventral view, same as C. H. Ventral view, same as D. I. Ventral view, 32 mm long [3229], Philippines, Luzon (PNM 041264). 
In addition, in some animals the tip of the dorsal papillae (with and without dorsal eyes) can be bright yellow. The foot varies from gray (light or dark) to yellow or orange. The hyponotum is almost always yellow, from pale yellow to bright yellow and even orange. This variable yellow component can cover the entire hyponotum or just an outer ring (the inner ring being light to dark gray). The color of the foot and of the hyponotum of an individual can change rapidly, especially when disturbed. The ocular tentacles are brown (variable from light to dark) and may or may not be speckled with tiny white dots, exactly like the head. The ocular tentacles are short (just a few millimeters long).

No live pictures were available for unit \#3, so the following description is based on preserved specimens (Fig. 10). It is possible that bright colors (yellow, orange) were lost during preservation on both the ventral and dorsal sides. The background of the dorsal notum is brown, mottled with darker or lighter areas. The foot is light gray. The hyponotum is gray-brown, with a reddish hue on the margin (which could possibly be orange in live animals). The color of the ocular tentacles (retracted, likely short) cannot be determined.

Generally speaking, the dorsal notum of any given live animal can rapidly change from almost perfectly smooth to covered by many papillae. However, when animals are not disturbed, the dorsum is usually covered by papillae of various sizes. In some animals, larger papillae may be arranged in two longitudinal and lateral ridges (on either side of the median line), but those ridges can appear and disappear rapidly. Some papillae bear from two to four black dorsal eyes at their tip (most papillae bear three eyes). The number of papillae with dorsal eyes is variable (between 10 and 15, on average) and they mostly are on the central part of the notum. Their tip is usually yellow, but not always. A central, much larger papilla, which bears four dorsal eyes (sometimes three), is entirely retractable within the notum. In addition to all these large papillae, the notum is covered by smaller, rounded papillae, which can make it look granular.

\section{External morphology (Fig. 11A-B)}

Preserved specimens no longer display the color of live animals. The body is not flattened (although, exceptionally, animals on mud with a thin layer of water can look flattened). The notum is oval. Dorsal gills are absent. The large, central, retractable papilla at the center of the notum can only be seen in live animals. In preserved specimens, it is retracted inside the notum. The hyponotum is horizontal. The width of the hyponotum relative to the total width of the ventral surface (pedal sole and hyponotum) varies among individuals, from approximately one third to half. In the anterior region, the left and right ocular tentacles are superior to the mouth. Eyes are located at the tip of the two ocular tentacles. Inferior to the ocular tentacles, superior to the mouth, the head bears a pair of oral lobes. The latter are smooth, with no transversal protuberance. The male opening (of the copulatory complex) is below and to the left of the right ocular tentacle (i.e., between the two ocular tentacles). The anus is posterior, median, close to the edge of the pedal sole. On the right side (to the left in ventral view), a peripodial groove

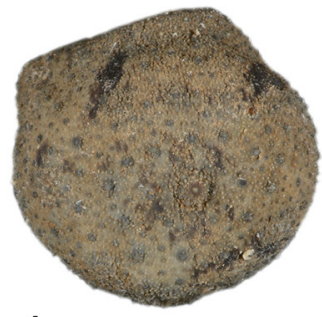

A

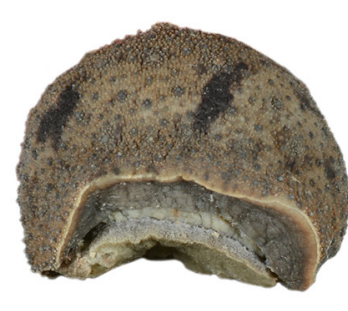

B

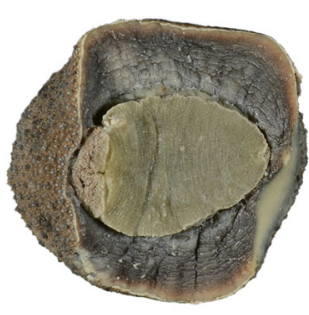

C

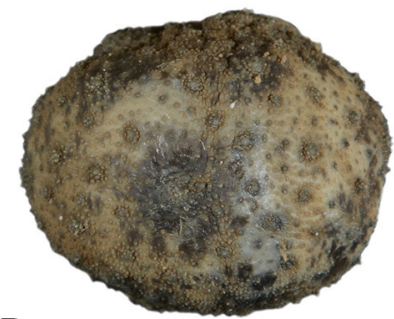

D

Fig. 10. Paromoionchis tumidus (Semper, 1880) comb. nov. unit \#3, preserved specimens, Papua New Guinea, Madang. A. Dorsal view, 13 mm long [5432] (MNHN IM-2013-10478). B. Lateral view, same as A. C. Ventral view, same as A. D. Dorsal view, 14 mm long [5433] (MNHN IM-2013-10479). 
is present at the junction between the foot and the hyponotum, running longitudinally from the buccal area to the posterior end, a few millimeters from the anus and the pneumostome. The pneumostome is median. Its position on the hyponotum relative to the notum margin and the edge of the pedal sole varies among individuals but averages in the middle. The position of the female pore (at the posterior end of the peripodial groove) does not vary much among individuals.

\section{Visceral cavity and pallial complex}

The anterior pedal gland is oval and flattened, lying free on the floor of the visceral cavity below the buccal mass. The heart, enclosed in the pericardium, is on the right side of the visceral cavity, slightly posterior to the middle. From the anterior ventricle an anterior vessel exits that supports several anterior organs such as the buccal mass, the nervous system and the copulatory complex. The auricle is posterior. The kidney is more or less symmetrical, the right and left parts being equally developed. The kidney is intricately attached to the respiratory complex. The lung is in two more or less symmetrical parts, left and right.

\section{Digestive system (Figs 12-15)}

There are no jaws. The left and right salivary glands, heavily branched, join the buccal mass dorsally, on either side of the esophagus. The radula is in between two large postero-lateral muscular masses. Radulae measure up to $5.2 \mathrm{~mm}$ in length (unit \#1), $4.1 \mathrm{~mm}$ (unit \#2) and $2.8 \mathrm{~mm}$ (unit \#3). Each radular row contains a rachidian tooth and two half rows of lateral teeth of similar size and shape. Examples of radular formulae are presented in Table 4. The rachidian teeth are unicuspid: the median cusp is always present; there are no conspicuous cusps on the lateral sides of the base of the rachidian tooth. The length of the rachidian teeth (approximately $25 \mu \mathrm{m}$ ) tend to be approximately half the size of the lateral teeth (approximately $50 \mu \mathrm{m}$ ). The lateral aspect of the base of the rachidian teeth is straight, occasionally slightly convex. The half rows of lateral teeth form an angle of $45^{\circ}$ with the rachidian axis. With the
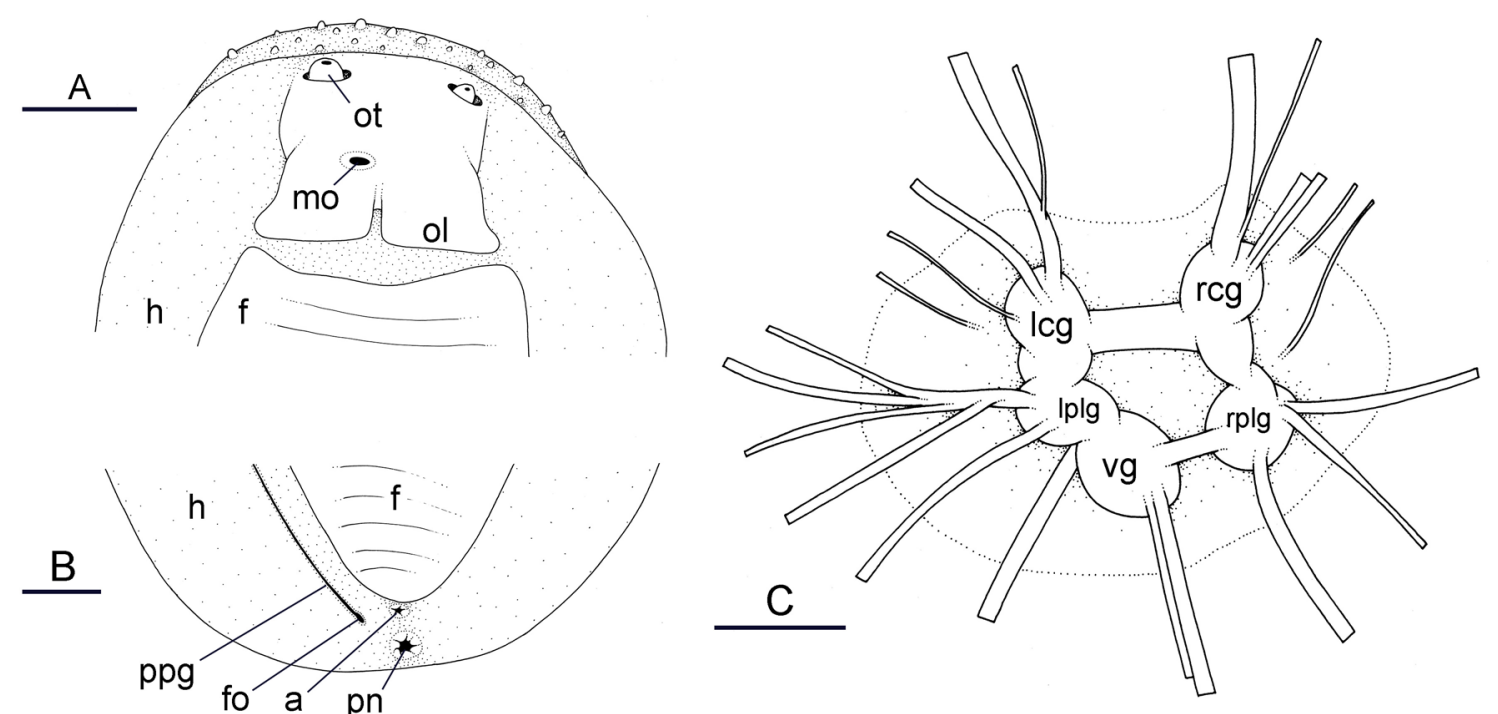

Fig. 11. Paromoionchis tumidus (Semper, 1880) comb. nov., external morphology and nervous system. A. Anterior, ventral view, lectotype of Onchidium mertoni Simroth, 1918 (ZMB 121591a). B. Unit \#1, posterior, ventral view, Indonesia, Sulawesi [2240] (UMIZ 00125). C. Nervous system, dorsal view, same as $\mathrm{B}$. Abbreviations: $\mathrm{a}=$ anus; $\mathrm{f}=$ foot; fo = female opening; $\mathrm{h}=$ hyponotum; $1 \mathrm{cg}=$ left cerebral ganglion; lplg = left pleural ganglion; mo = male opening; ol = oral lobe; ot $=$ ocular tentacle; $\mathrm{pn}=$ pneumostome; $\mathrm{ppg}=$ peripodial groove; $\mathrm{rcg}=$ right cerebral ganglion; $\mathrm{rplg}=$ right pleural ganglion; $\mathrm{vg}=$ visceral ganglion. Scales: $\mathrm{A}-\mathrm{B}=2 \mathrm{~mm} ; \mathrm{C}=0.5 \mathrm{~mm}$. 


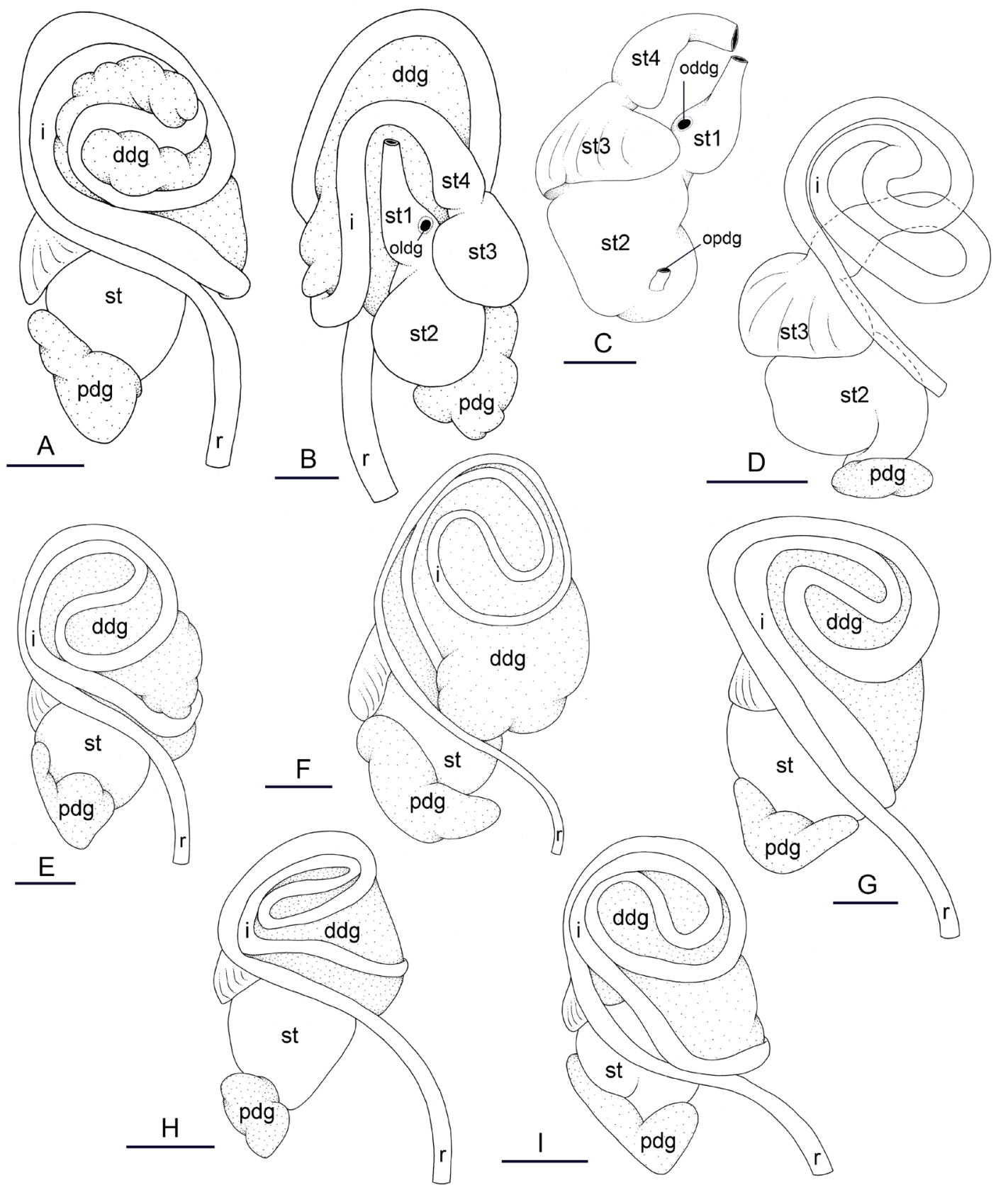

Fig. 12. Paromoionchis tumidus (Semper, 1880) comb. nov., digestive system. A. Unit \#1, dorsal view, Indonesia, Sulawesi [2240] (UMIZ 00125). B. Ventral view (lateral digestive gland removed), same as A. C. Stomach, dorsal view, same as A. D. Dorsal view (digestive gland removed prior to present study, intestinal loops loose), holotype of Onchidium honkongense Britton, 1984 (NHM 1982290). E. Unit \#2, dorsal view, Australia, Northern Territory [1638] (NTM P.57623). F. Unit \#3, dorsal view, Papua New Guinea, Madang [5433] (MNHN IM-2013-10479). G. Dorsal view, lectotype of Onchidium mertoni Simroth, 1918 (ZMB 121591a). H. Dorsal view, lectotype of Onchidium tumidum (ZMB 39019a). I. Dorsal view, lectotype of Onchidium samarense Semper, 1880 (ZMB 39025a). Abbreviations: $\mathrm{ddg}=$ dorsal lobe of digestive gland; $\mathrm{i}=$ intestine; oddg = opening of dorsal lobe of digestive gland; oldg = opening of lateral lobe of digestive gland; opdg = opening of posterior lobe of digestive gland; $p d g=$ posterior lobe of digestive gland; $r=$ rectum; $s t=$ stomach; $s t 1=$ stomach chamber 1 ; st $2=$ stomach chamber $2 ; \mathrm{st} 3=$ stomach chamber $3 ; \mathrm{st} 4=$ stomach chamber 4 . Scales: A-C, F = 2 mm; $\mathrm{D}, \mathrm{I}=3 \mathrm{~mm} ; \mathrm{E}=5 \mathrm{~mm} ; \mathrm{G}=1 \mathrm{~mm} ; \mathrm{H}=4 \mathrm{~mm}$. 
Table 4. Radular formulae for the five species of Paromoionchis gen. nov. following the same format: number of rows $\times$ (number of lateral teeth per left half row -1 rachidian tooth - number of lateral teeth per right half row). Each DNA extraction number corresponds to one particular individual. DNA extraction numbers are used on Figs 1-4 (the phylogenetic trees), Table 1 and in the material examined section for each species.

\begin{tabular}{|c|c|c|c|c|}
\hline Species & Radular formula & Spm length (mm) & Voucher & DNA extraction number \\
\hline P. tumidus unit \#1 & $70 \times 80-1-80$ & 55 & MTQ & 2637 \\
\hline- & $65 \times 60-1-60$ & 50 & UMIZ 00136 & 5102 \\
\hline - & $60 \times 75-1-75$ & 40 & PNM 041258 & 3344 \\
\hline- & $55 \times 80-1-80$ & 45 & NTM P.57620 & 1634 \\
\hline- & $55 \times 80-1-80$ & 20 & UMIZ 00123 & 1798 \\
\hline- & $55 \times 65-1-65$ & 45 & UMIZ 00129 & 2832 \\
\hline- & $55 \times 65-1-65$ & 35 & PNM 041256 & 3205 \\
\hline- & $50 \times 60-1-60$ & 30 & UMIZ 00131 & 2950 \\
\hline- & $50 \times 60-1-60$ & 25 & UMIZ 00133 & 3051 \\
\hline P. tumidus unit \#2 & $65 \times 105-1-105$ & 42 & NTM P.57623 & 1638 \\
\hline- & $60 \times 85-1-85$ & 27 & PNM 041265 & 3237 \\
\hline- & $45 \times 65-1-65$ & 22 & PNM 041262 & 3172 \\
\hline P. tumidus unit \#3 & $60 \times 65-1-65$ & 18 & MNHN IM-2013-10478 & 5432 \\
\hline- & $50 \times 60-1-60$ & 17 & MNHN IM-2013-10479 & 5433 \\
\hline P. daemelii & $75 \times 105-1-105$ & 60 & AM C.468917.001 & 1519 \\
\hline- & $70 \times 90-1-90$ & 50 & AM C. 468919.001 & 1521 \\
\hline- & $55 \times 60-1-60$ & 17 & AM C.468911.001 & 1510 \\
\hline P. boholensis unit \#1 & $70 \times 80-1-80$ & 28 & PNM 041266 & 3288 Holotype \\
\hline- & $65 \times 85-1-85$ & 35 & PNM 041269 & 3372 \\
\hline- & $60 \times 70-1-70$ & 16 & PNM 041268 & 3283 \\
\hline P. boholensis unit \#2 & $65 \times 90-1-90$ & 35 & UMIZ 00140 & 3117 \\
\hline- & $60 \times 85-1-85$ & 18 & UMIZ 00149 & 2911 \\
\hline- & $60 \times 80-1-80$ & 45 & UMIZ 00146 & 2851 \\
\hline P. penangensis & $60 \times 70-1-70$ & 48 & USMMC 00062 & 6020 \\
\hline- & $55 \times 60-1-60$ & 30 & USMMC 00060 & 5991 \\
\hline- & $50 \times 60-1-60$ & 26 & USMMC 00059 & 6037 Holotype \\
\hline P. goslineri unit \#1 & $65 \times 65-1-65$ & 22 & PNM 041272 & 3221 \\
\hline- & $60 \times 70-1-70$ & 25 & PNM 041271 & 3233 Holotype \\
\hline- & $55 \times 75-1-75$ & 28 & PNM 041273 & 3232 \\
\hline- & $60 \times 70-1-70$ & 20 & PNM 041272 & 6049 \\
\hline P. goslineri unit \#2 & $5570-1-70$ & 22 & UMIZ 00155 & 3078 \\
\hline- & $55 \times 60-1-60$ & 35 & UMIZ 00159 & 5145 \\
\hline- & $50 \times 65-1-65$ & 18 & UMIZ 00153 & 2241 \\
\hline
\end{tabular}

exception of the few innermost and few outermost lateral teeth, the size and shape of the lateral teeth do not vary along the half row, nor do they vary among half rows. The lateral teeth seem to be unicuspid with a flattened and curved hook (approximately $50 \mu \mathrm{m}$ long) with a rounded tip, but there is also a pointed spine on the outer lateral expansion of the base (basal lateral spine). In most cases, the basal lateral spine cannot be observed because it is hidden below the hook of the next, outer lateral tooth. It can only be observed when the teeth are not too close (such as in the innermost and outermost regions) 
or when teeth are placed in an unusual position. The inner and outer lateral aspects of the hook of the lateral teeth are straight (i.e., not wavy and not with any protuberance).

The esophagus is narrow and straight, with thin internal folds. The esophagus enters the stomach anteriorly. Only a portion of the posterior aspect of the stomach can be seen in dorsal view because it is partly covered by the lobes of the digestive gland. The dorsal lobe is mainly on the right. The left, lateral lobe is mainly ventral. The posterior lobe covers the posterior aspect of the stomach. The stomach is a U-shaped sac divided into four chambers. The first chamber, which receives the esophagus, is delimited by thin tissue and receives the ducts of the dorsal and lateral lobes of the digestive gland. The second, posterior chamber, delimited by thick muscular tissue, receives the duct of the posterior lobe of the digestive gland. The third, funnel-shaped chamber is delimited by thin tissue with high ridges internally. The fourth chamber is continuous and externally similar to the third, but it bears only low, thin ridges internally. The intestine is long and narrow and the intestinal loops are of type II. There is no rectal gland.

\section{Nervous system (Fig. 11C)}

The circum-esophageal nerve ring is post-pharyngeal and pre-esophageal. The paired cerebral ganglia are close and the cerebral commissure is short (but its length does vary among individuals). Paired pleural and pedal ganglia are also all distinct. The visceral commissure is short but distinctly present and
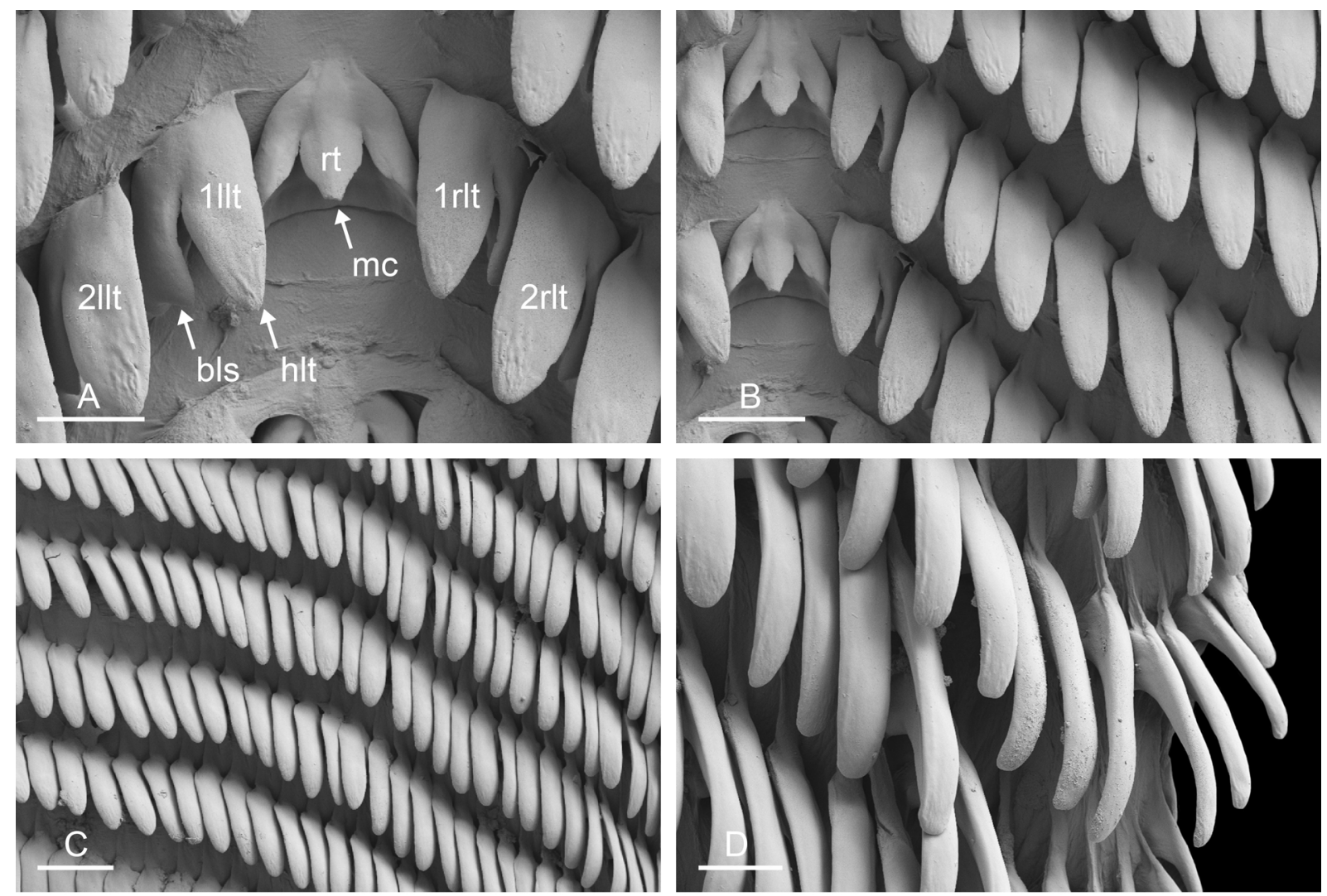

Fig. 13. Paromoionchis tumidus (Semper, 1880) comb. nov. unit \#1, radula, Indonesia, Bali [3051] (UMIZ 00133). A. Rachidian and innermost lateral teeth. B. Lateral teeth with rachidian teeth. C. Lateral teeth. D. Outermost lateral teeth. Abbreviations: 11 lt $=$ first left lateral tooth; $1 \mathrm{rlt}=$ first right lateral tooth; $21 \mathrm{lt}=$ second left lateral tooth; $2 \mathrm{rlt}=$ second right lateral tooth; bls $=$ basal lateral spine; hlt $=$ hook of lateral tooth; $\mathrm{mc}=$ median cusp; $\mathrm{rt}=$ rachidian tooth. Scales: $\mathrm{A}=20 \mu \mathrm{m} ; \mathrm{B}=30 \mu \mathrm{m}$; $\mathrm{C}=50 \mu \mathrm{m} ; \mathrm{D}=10 \mu \mathrm{m}$. 

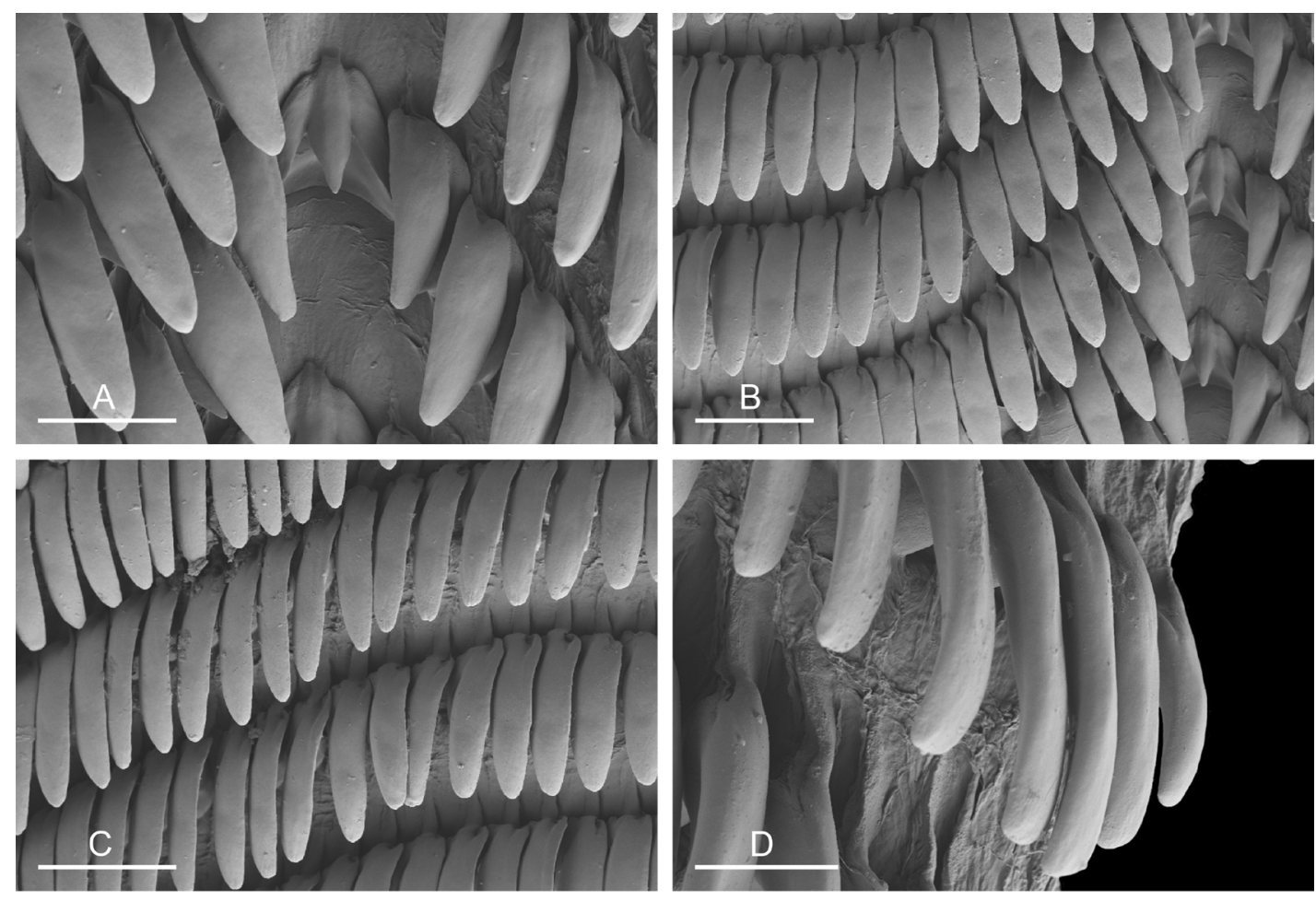

Fig. 14. Paromoionchis tumidus (Semper, 1880) comb. nov. unit \#2, radula, Australia, Northern Territory [1638] (NTM P.57623). A. Rachidian and innermost lateral teeth. B. Lateral teeth with rachidian teeth. C. Lateral teeth. D. Outermost lateral teeth. Scales: A $=30 \mu \mathrm{m} ; \mathrm{B}-\mathrm{C}=50 \mu \mathrm{m} ; \mathrm{D}=20 \mu \mathrm{m}$.
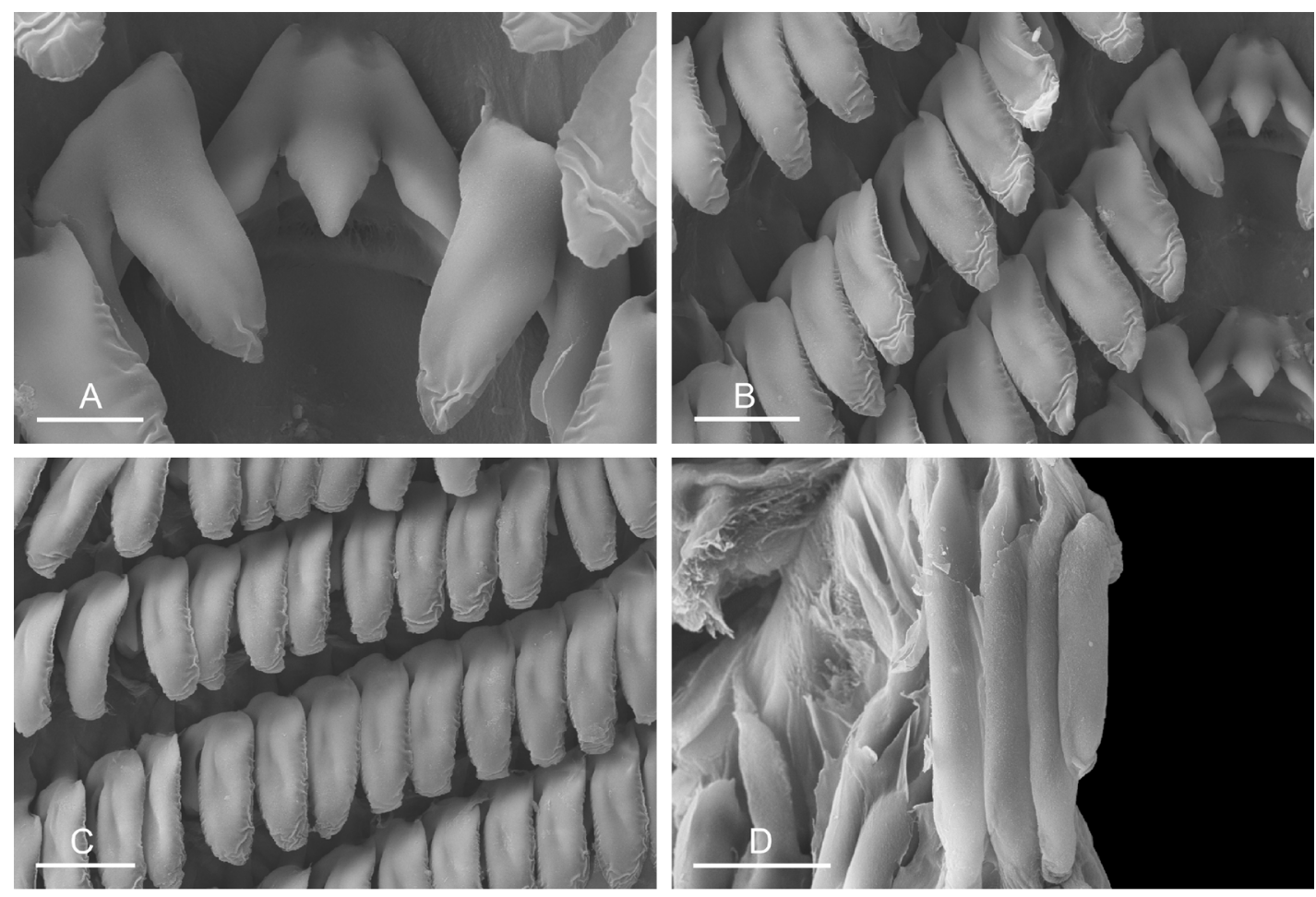

Fig. 15. Paromoionchis tumidus (Semper, 1880) comb. nov. unit \#3, radula, Papua New Guinea, Madang. A. Rachidian and innermost lateral teeth, [5432] (MNHN IM-2013-10478). B. Lateral teeth with rachidian teeth, same as A. C. Lateral teeth, same as A. D. Outermost lateral teeth, [5433] (MNHN IM-2013-10479). Scales: $A=10 \mu \mathrm{m} ; \mathrm{B}, \mathrm{D}=20 \mu \mathrm{m} ; \mathrm{C}=25 \mu \mathrm{m}$. 
the visceral ganglion is more or less median. Cerebro-pleural and pleuro-pedal connectives are short and pleural and cerebral ganglia touch each other on either side. Nerves from the cerebral ganglia innervate the buccal area and the ocular tentacles and, on the right side, the penial complex. Nerves from the pedal ganglia innervate the foot. Nerves from the pleural ganglia innervate the lateral and dorsal regions of the mantle. Nerves from the visceral ganglia innervate the visceral organs.

\section{Reproductive system (Figs 16-23)}

Sexual maturity is correlated with animal length. Mature individuals have large female organs (with a large female gland mass) and fully-developed male copulatory parts. Immature individuals $(<15 \mathrm{~mm}$ long) may have inconspicuous (or no) female organs and rudimentary anterior male parts.

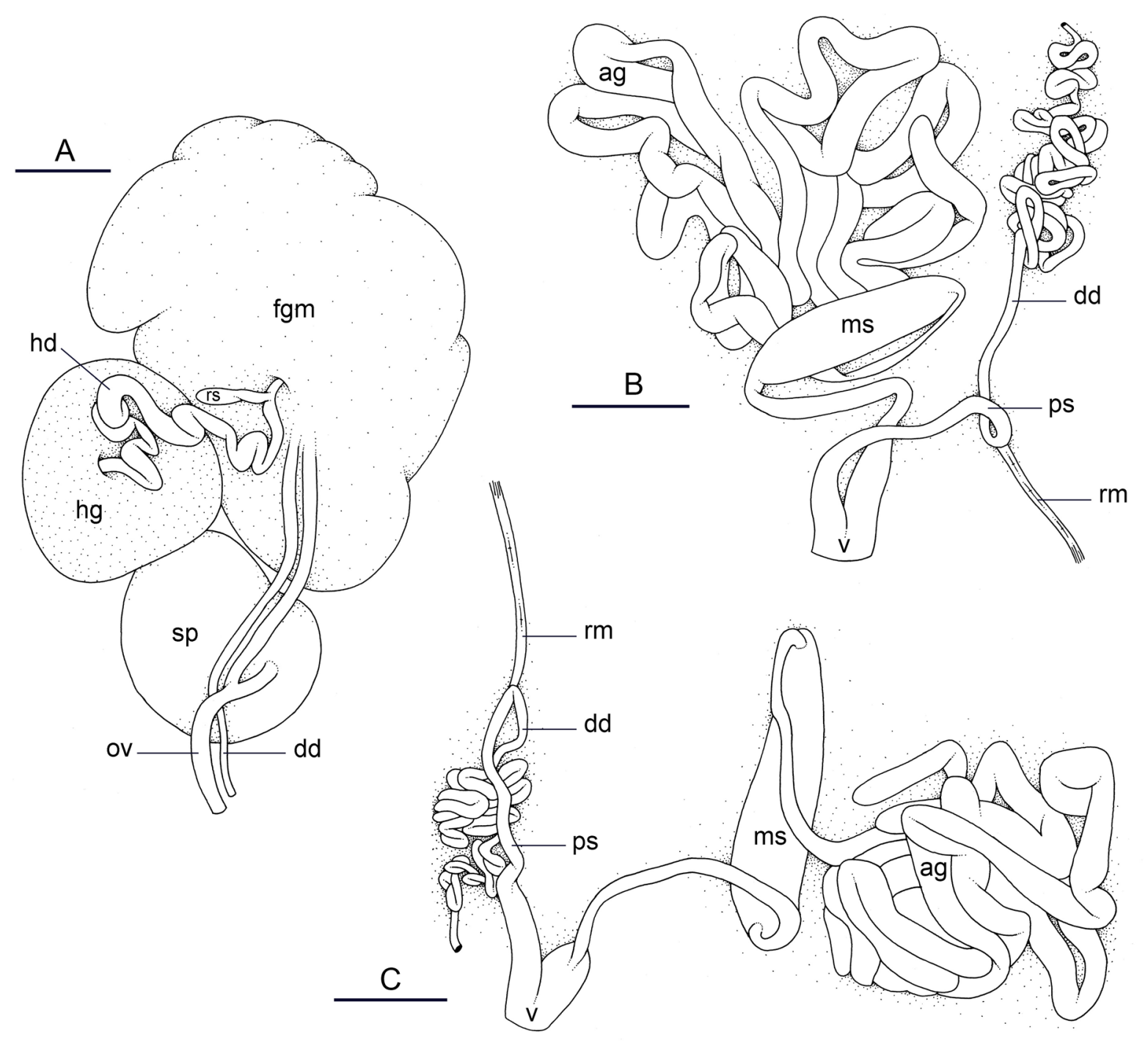

Fig. 16. Paromoionchis tumidus (Semper, 1880) comb. nov. unit \#1, reproductive system. A. Posterior hermaphroditic (female) reproductive system, Australia, Northern Territory [1634] (NTM P.57620). B. Male copulatory organs, Philippines, Bohol [3344] (PNM 041258). C. Male copulatory organs, lectotype of Onchidium tumidum (ZMB 39019a). Abbreviations: ag = accessory penial gland; $\mathrm{dd}=$ deferent duct; fgm = female gland mass; $\mathrm{hd}=$ hermaphroditic duct; $\mathrm{hg}=$ hermaphroditic gland; $\mathrm{ms}=$ muscular sac (of accessory penial gland); ov = oviduct; $\mathrm{ps}=$ penial sheath; $\mathrm{rm}=$ retractor muscle; $\mathrm{rs}=$ receptaculum seminis; $\mathrm{sp}=$ spermatheca; $\mathrm{v}=$ vestibule. Scales $=3 \mathrm{~mm}$. 
The female organs are located at the posterior end of the visceral cavity, mixed with some male parts (Figs 16A, 17A-B). The hermaphroditic gland is a single mass, joining the spermoviduct through the hermaphroditic duct (which conveys the eggs and the autosperm). There is a narrow and bent

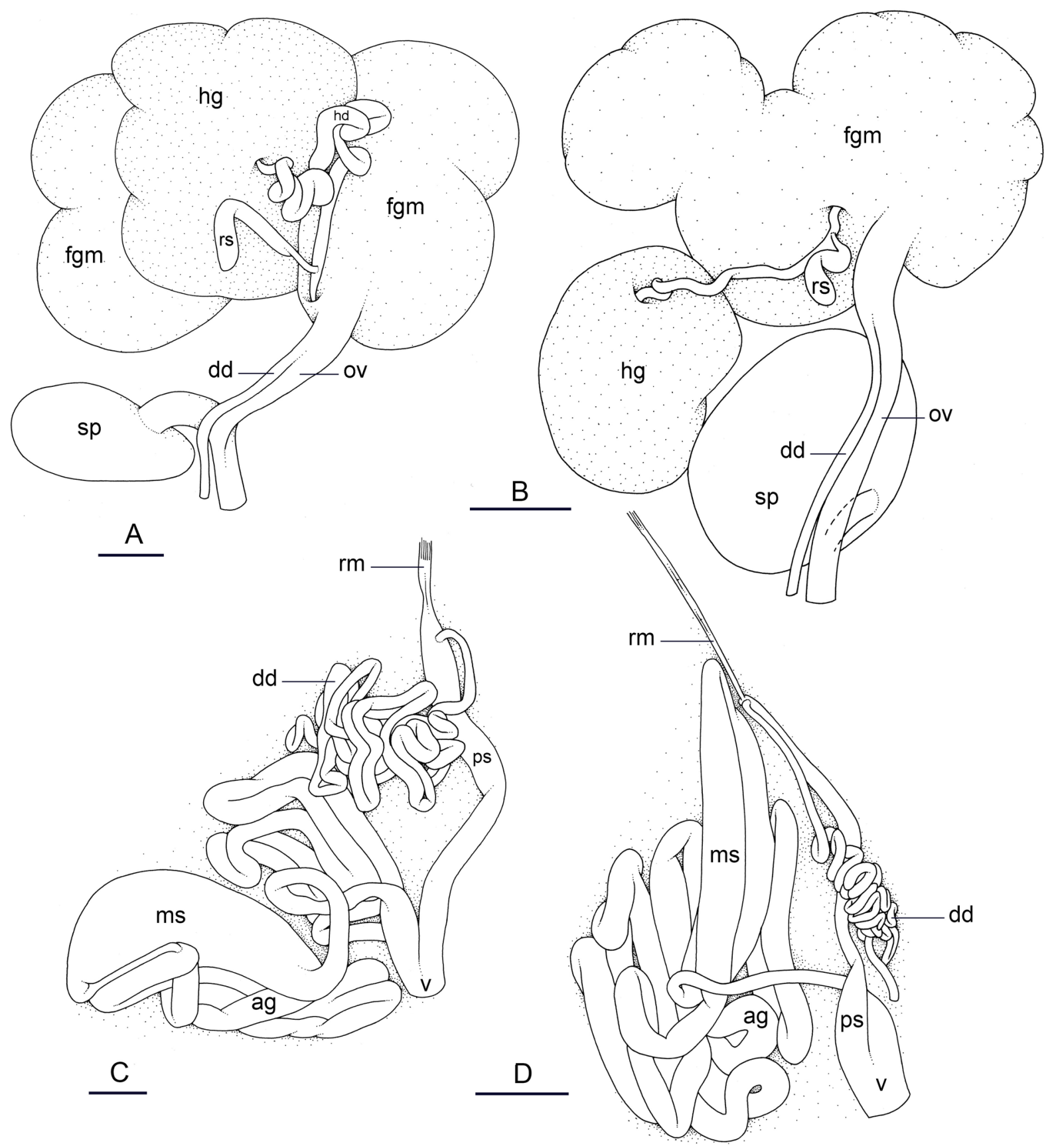

Fig. 17. Paromoionchis tumidus (Semper, 1880) comb. nov., reproductive system. A. Unit \#3, posterior hermaphroditic (female) reproductive system, Papua New Guinea, Madang [5433] (MNHN IM2013-10479). B. Unit \#2, posterior hermaphroditic (female) reproductive system, Australia, Northern Territory [1638] (NTM P.57623). C. Male copulatory organs, same as A. D. Male copulatory organs, same as B. Abbreviations: ag = accessory penial gland; $\mathrm{dd}=$ deferent duct; fgm = female gland mass; $\mathrm{hd}=$ hermaphroditic duct; $\mathrm{hg}=$ hermaphroditic gland; $\mathrm{ms}=$ muscular sac (of accessory penial gland); $\mathrm{ov}=$ oviduct; $\mathrm{ps}=$ penial sheath; $\mathrm{rm}=$ retractor muscle; $\mathrm{rs}=$ receptaculum seminis; $\mathrm{sp}=$ spermatheca; $\mathrm{v}=$ vestibule. Scales: $\mathrm{A}, \mathrm{C}=1 \mathrm{~mm} ; \mathrm{B}, \mathrm{D}=3 \mathrm{~mm}$. 
receptaculum seminalis (caecum) along the hermaphroditic duct. The female gland mass contains various glands (mucus and albumen) which can hardly be separated by dissection and of which the exact connections remain uncertain. The hermaphroditic duct becomes the spermoviduct (which conveys eggs, exosperm and autosperm). Proximally, the spermoviduct is not divided (at least externally) and is embedded within the female gland mass. Distally, the spermoviduct branches into the deferent duct (which conveys the autosperm up to the anterior region, running through the body wall) and the oviduct.
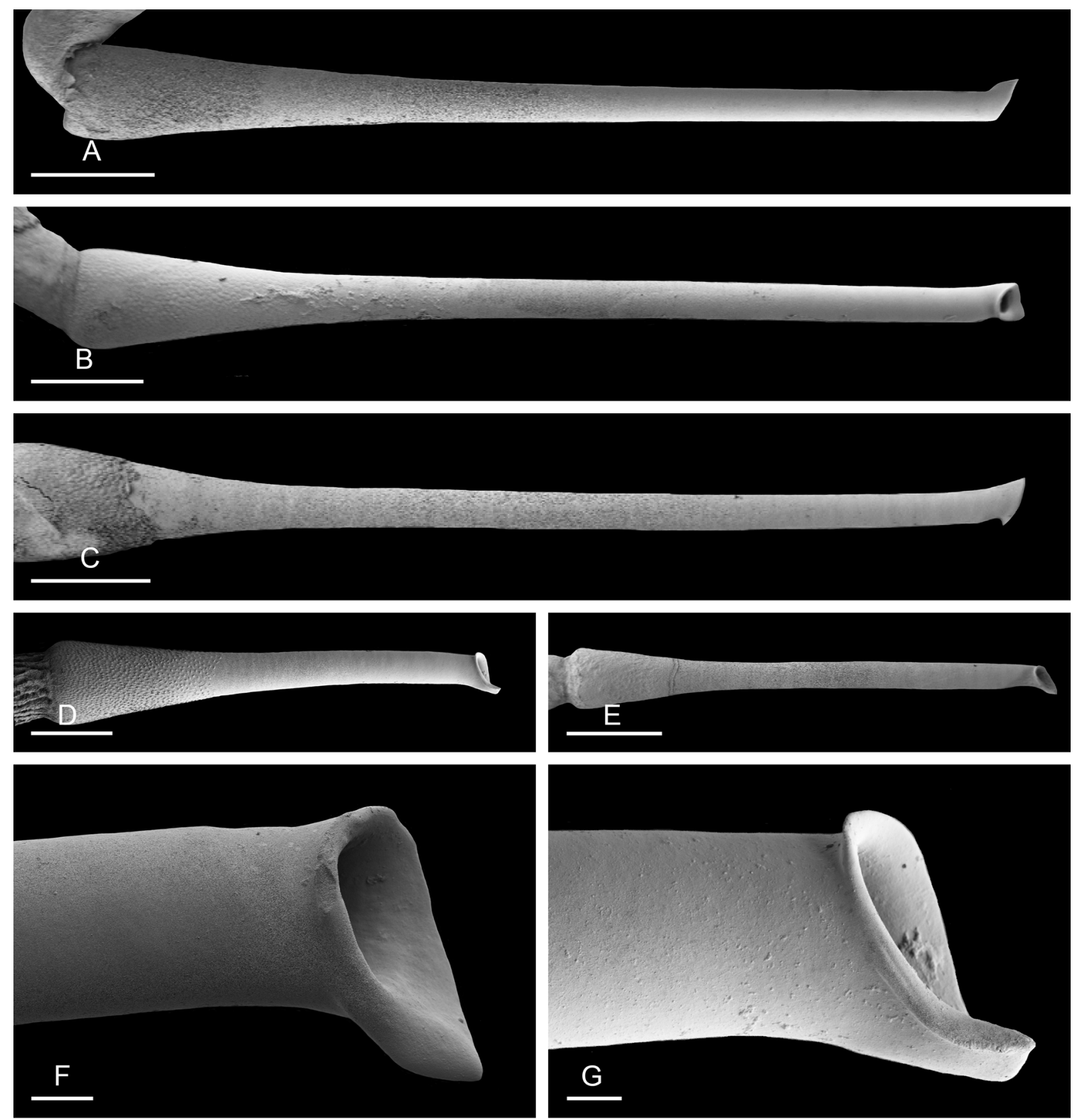

Fig. 18. Paromoionchis tumidus (Semper, 1880) comb. nov. unit \#1, spine of accessory penial gland. A. Indonesia, Lombok [2950] (UMIZ 00131). B. Philippines, Bohol [3344] (PNM 041258). C. Indonesia, Ambon [2832] (UMIZ 00129). D. Australia, Northern Territory [1634] (NTM P.57620). E. Australia, Queensland [2637] (MTQ). F. Distal tip of spine, Indonesia, Halmahera [5102] (UMIZ 00136). G. Distal tip of spine, same as D. Scales: A-D $=200 \mu \mathrm{m} ; \mathrm{E}=400 \mu \mathrm{m} ; \mathrm{F}-\mathrm{G}=20 \mu \mathrm{m}$. 

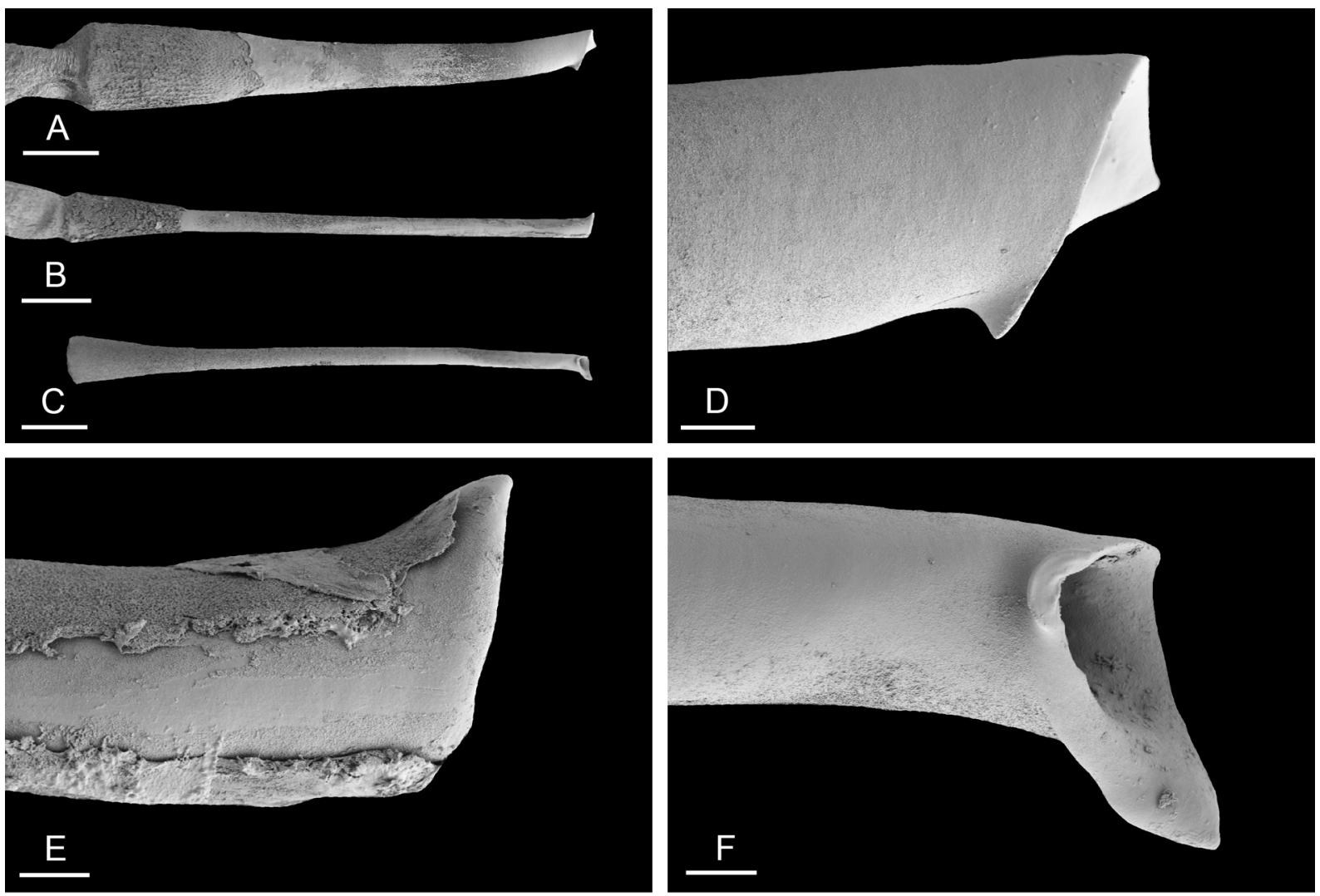

Fig. 19. Paromoionchis tumidus (Semper, 1880) comb. nov. unit \#2, spine of accessory penial gland. A. Australia, Northern Territory [1638] (NTM P.57623). B. Philippines, Luzon [3237] (PNM 041265). C. Philippines, Luzon [3172] (PNM 041262). D. Distal tip of spine, same as A. E. Distal tip of spine, same as B. F. Distal tip of spine, same as C. Scales: A $=150 \mu \mathrm{m} ; \mathrm{B}-\mathrm{C}=200 \mu \mathrm{m}$; D-F $=20 \mu \mathrm{m}$.

The free oviduct conveys the eggs up to the female opening and the exosperm from the female opening up to the fertilization chamber. The large, ovate-spherical spermatheca connects to the oviduct through a narrow and short duct. The oviduct is narrow and straight. There is no vaginal gland.
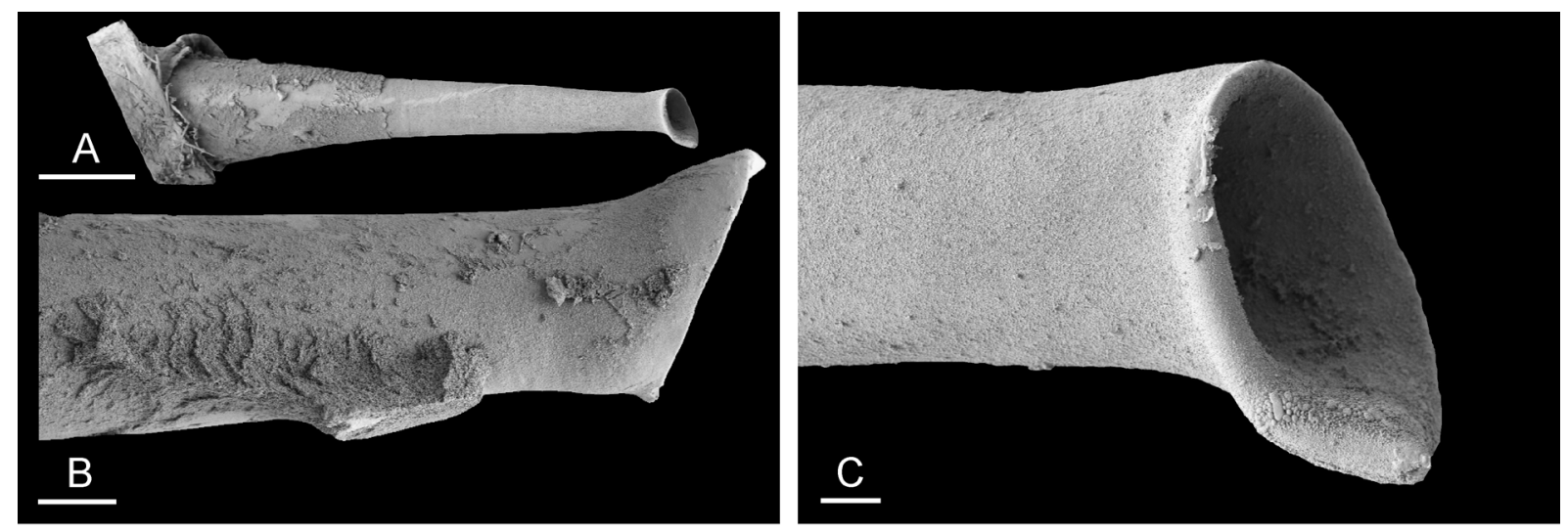

Fig. 20. Paromoionchis tumidus (Semper, 1880) comb. nov. unit \#3, spine of accessory penial gland, Papua New Guinea, Madang. A. [5432] (MNHN IM-2013-10478). B. [5433] (MNHN IM-2013-10479). C. Distal tip of spine, same as A. Scales: A $=100 \mu \mathrm{m} ; \mathrm{B}=20 \mu \mathrm{m} ; \mathrm{C}=10 \mu \mathrm{m}$. 

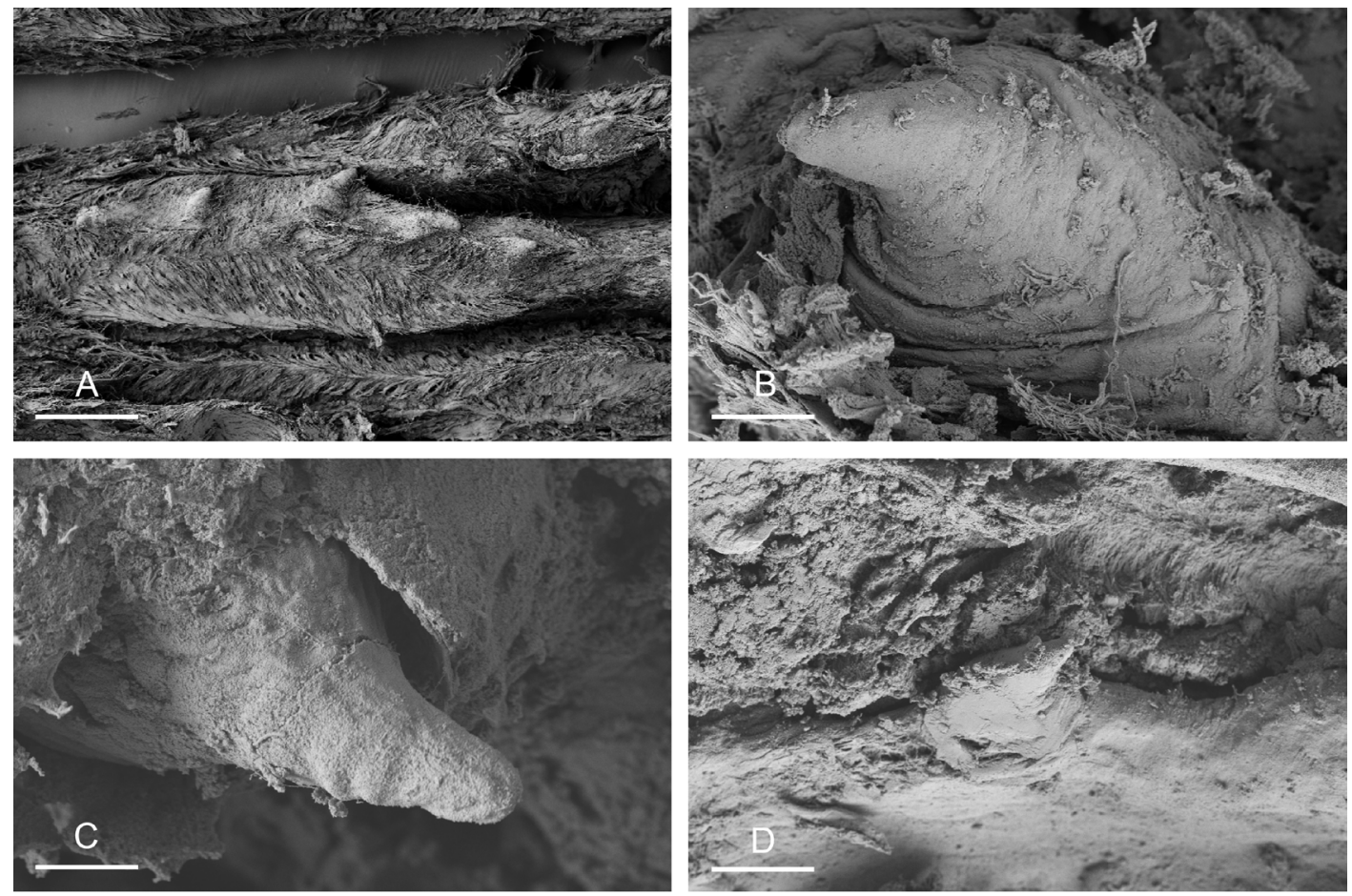

Fig. 21. Paromoionchis tumidus (Semper, 1880) comb. nov. unit \#1, penial hooks. A. Indonesia, Sulawesi [2240] (UMIZ 00125). B. Indonesia, Ambon [2832] (UMIZ 00129). C. Lectotype of Onchidium mertoni Simroth, 1918 (ZMB 121591a). D. Lectotype of Onchidium tumidum (ZMB 39019a). Scales: $\mathrm{A}=60 \mu \mathrm{m} ; \mathrm{B}=10 \mu \mathrm{m} ; \mathrm{C}=4 \mu \mathrm{m} ; \mathrm{D}=25 \mu \mathrm{m}$.
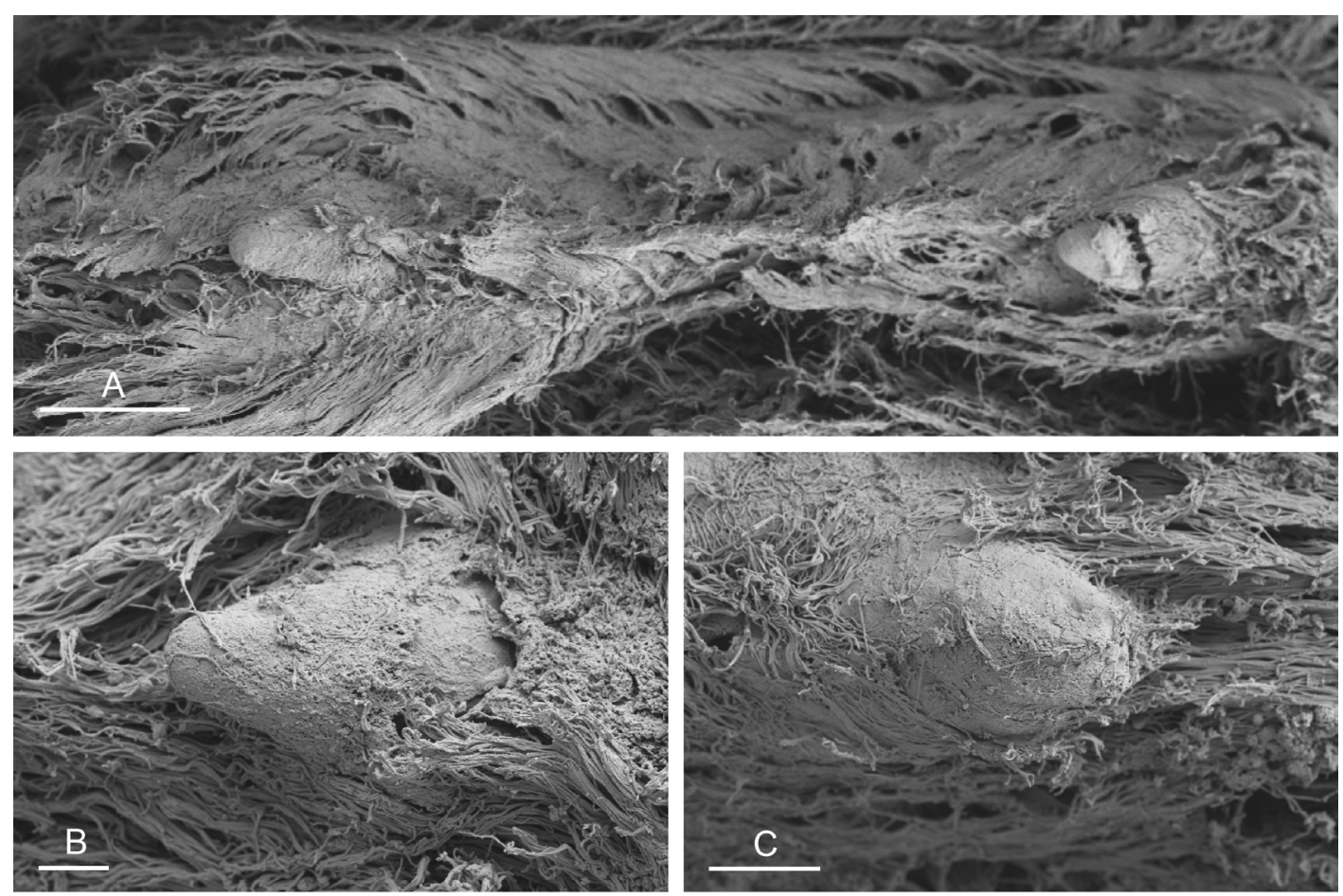

Fig. 22. Paromoionchis tumidus (Semper, 1880) comb. nov. unit \#2, penial hooks. A. Indonesia, Sumatra [1794] (UMIZ 00138). B. Philippines, Luzon [3237] (PNM 041265). C. Same as B. Scales: A = $20 \mu \mathrm{m}$; $\mathrm{B}=4 \mu \mathrm{m} ; \mathrm{C}=6 \mu \mathrm{m}$. 
The male anterior organs consist of the penial complex (penis, penial sheath, vestibule, deferent duct, retractor muscle) and the accessory penial gland (Figs 16B-C, 17C-D). The penial complex and the accessory penial gland share the same vestibule and the same anterior male opening. The penial gland is a long, tube-like flagellum with a proximal dead end. The length of the flagellum of the penial gland varies among individuals but it is always heavily coiled. Near its distal end (just before the hollow spine), the flagellum is enlarged into a thick muscular sac. Distally, the flagellum ends in a hard, hollow spine protected by a sheath which opens into the vestibule. The hollow spine is narrow, elongated and slightly curved (Figs 18-20). Its base is conical. Its diameter is between 60 and $100 \mu \mathrm{m}$. The diameter of the opening at its tip measures between 30 and $60 \mu \mathrm{m}$. Its length ranges from $1 \mathrm{~mm}([1634]$ NTM P.57620) to 2 mm ([5619] ITBZC IM 00019, [5102] UMIZ 00136) for unit \#1, from $1.2 \mathrm{~mm}$ ([1638] NTM P.57623) to $1.8 \mathrm{~mm}$ ([3237] PNM 041265, [3172] PNM 041262) for unit \#2 and from $0.8 \mathrm{~mm}$ ([5433] MNHN IM-2013-10479) to $1 \mathrm{~mm}$ ([5432] MNHN IM-2013-10478) for unit \#3, and its shape does vary between individuals (Figs 18-20). There is no disc separating the spine of the penial gland and the vestibule.

The penial sheath is narrow and elongated (Figs 16B-C, 17C-D). The penial sheath protects the penis for its entire length. The beginning of the retractor muscle marks the separation between the penial sheath (and the penis inside) and the deferent duct. The retractor muscle is shorter than the penial sheath and inserts on the wall of the body cavity, near the heart. The deferent duct is also highly convoluted, with many loops. Inside the penial sheath, the penis is a narrow, elongated, soft, hollow tube of approximately $200 \mu \mathrm{m}$ in diameter. Inside the tube-like penis, six longitudinal ridges bear sparse, tiny, conical (but not pointed) hooks which are less than $20 \mu \mathrm{m}$ long in unit \#1, less than $22 \mu \mathrm{m}$ long in unit \#2 and less than $28 \mu \mathrm{m}$ in unit \#3 (Figs 21-23). When the penis is retracted inside the penial sheath, the hooks are inside the tube-like penis; during copulation, the penis is evaginated like a glove and the hooks are outside.
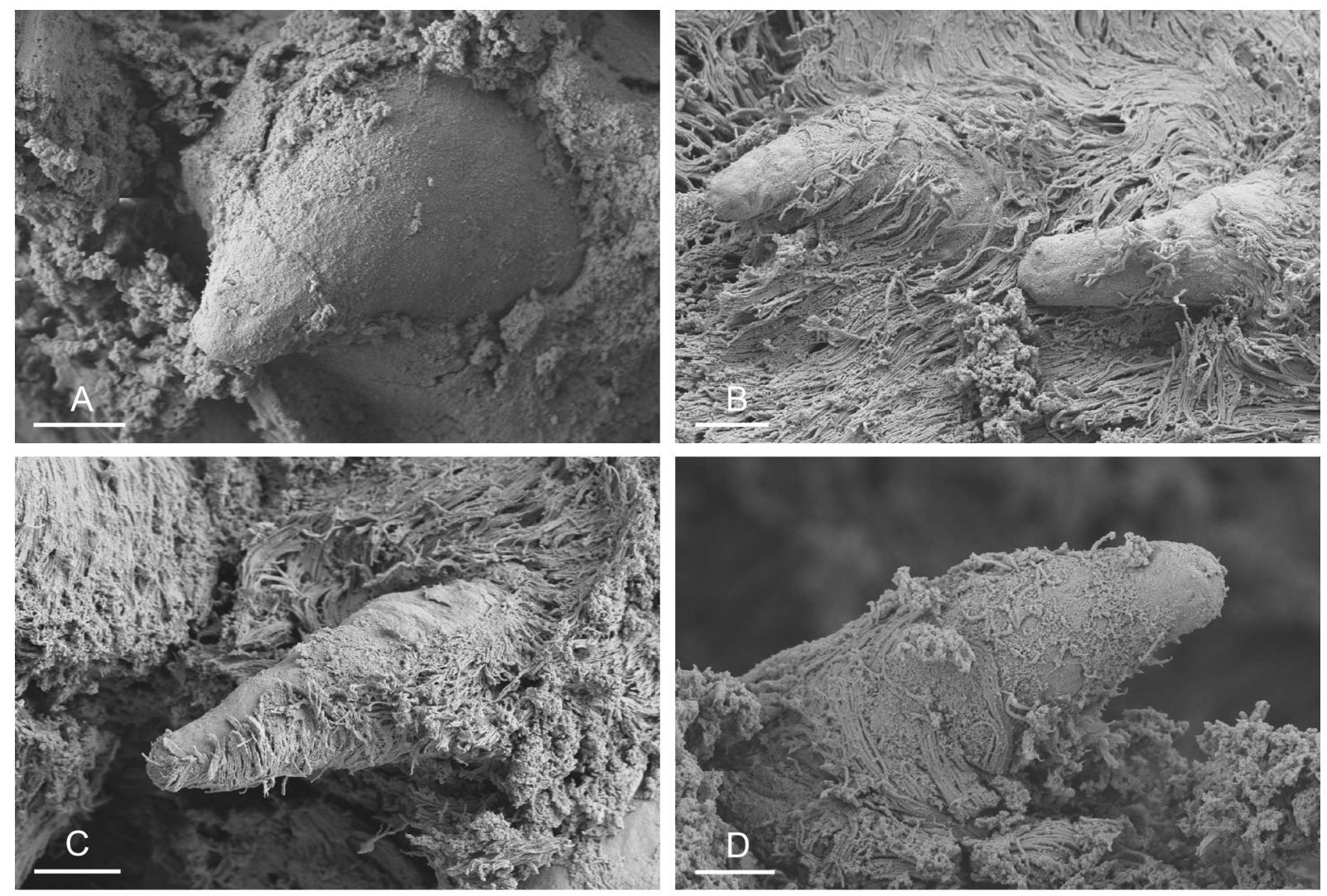

Fig. 23. Paromoionchis tumidus (Semper, 1880) comb. nov. unit \#3, penial hooks, Papua New Guinea, Madang. A. [5433] (MNHN IM-2013-10479). B. Same as A. C. [5432] (MNHN IM-2013-10478). D. Same as C. Scales: A, D $=3 \mu \mathrm{m} ; \mathrm{B}-\mathrm{C}=6 \mu \mathrm{m}$. 
DAYRAT B. et al., A new genus of mangrove onchidiid slugs

\section{Distinctive diagnostic features}

Externally, Paromoionchis tumidus (Semper, 1880) cannot be distinguished from other species of Paromoionchis gen. nov. Internally, the presence of penial hooks distinguishes it from other species of the genus (Table 3).

\section{Distribution (Fig. 6)}

All records here are new, except for the type localities.

Unit \#1. Australia: New South Wales, Northern Territory, Queensland. Brunei Darussalam. Hong Kong (type locality of Onchidium hongkongense). India: Andaman Islands. Indonesia: Ambon, Aru Islands, Bali, Halmahera, Lombok, Seram, Sulawesi, Sumatra. Japan. Malaysia: Peninsular Malaysia. Singapore (type locality of Onchidium tumidum). Philippines: Bohol, Luzon, Samar (type locality of Onchidium

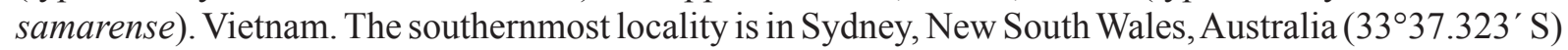
and the northernmost locality is in Misho Bay, Ehime Prefecture, Japan $\left(32^{\circ} 57.634^{\prime} \mathrm{N}\right)$.

Unit \#2. Australia: Northern Territory. Indonesia: Sumatra, Lombok. Philippines: Luzon.

Unit \#3. Papua New Guinea: Madang.

\section{Habitat (Figs 24-25)}

Paromoionchis tumidus unit \#1 is predominantly found on mud, hard or soft, inside or near mangroves, or on mudflats (Fig. 24). It is also found on old, muddy logs, inside or near mangroves. It occasionally is found on muddy sand, or even rocks and coral rubble, usually in the proximity of some mangrove trees. It is not found on rocky shores. Paromoionchis tumidus unit \#2 is found in mangroves, mostly on mud and occasionally on sand (Fig. 25). Paromoionchis tumidus unit \#3 is found in Nypa palm swamps and seems rare (only two specimens are known).

Paromoionchis tumidus is very common across its entire distribution range. It is by far the most abundant species of Paromoionchis gen. nov. and arguably the most abundant onchidiid species in the Indo-West Pacific. Most individuals of $P$. tumidus are part of unit \#1, because $P$. tumidus unit $\# 2$ is rare across its entire distribution (it is only known from a total of nine specimens collected at nine stations) and P. tumidus unit \#3 is restricted to two individuals from Papua New Guinea.

\section{Remarks}

The publication dates of the various sections of the volume on Landmollusken by Carl Semper in the Reisen im Archipel der Philippinen series were clarified by Johnson (1969). The species name Onchidium tumidum was published by Semper with a complete description (text and figures) in 1880 .

The anatomy of the species described here is fully compatible with Semper's original description of Onchidium tumidum as well as our own observation of the lectotype (and paralectotypes) from Singapore (Table 3). The most important characters are the lack of a rectal gland, a digestive system of type II, an accessory penial gland, a retractor muscle of the penis inserting near the heart, a male opening between the two eye tentacles (not just below the right eye tentacle), and a penis with hooks (Figs 12H, 21D). According to Semper (1880: 263, our translation), the male opening is "almost exactly midway between the two [eye tentacles]," but it actually is closer to the right tentacle. Also, Semper (1880: 263, our translation) described a penis with an "anterior tooth-bearing portion [which] is reduced, namely at most $2 \mathrm{~mm}$ long." It is confirmed here with SEM (Fig. 21D) that the penis of the lectotype bears tiny hooks $(<20 \mu \mathrm{m})$ and is fully compatible with the species described here.

The lectotype of $O$. mertoni is anatomically identical to the species described here, P. tumidus. Simroth did not describe the internal anatomy of $O$. mertoni, but a description of its lectotype is provided here. 
Simroth mentioned a male aperture below the right ocular tentacle, but it clearly is to the left of the right tentacle (Fig. 11A); the intestinal loops are of type II; the male apparatus includes an accessory penial
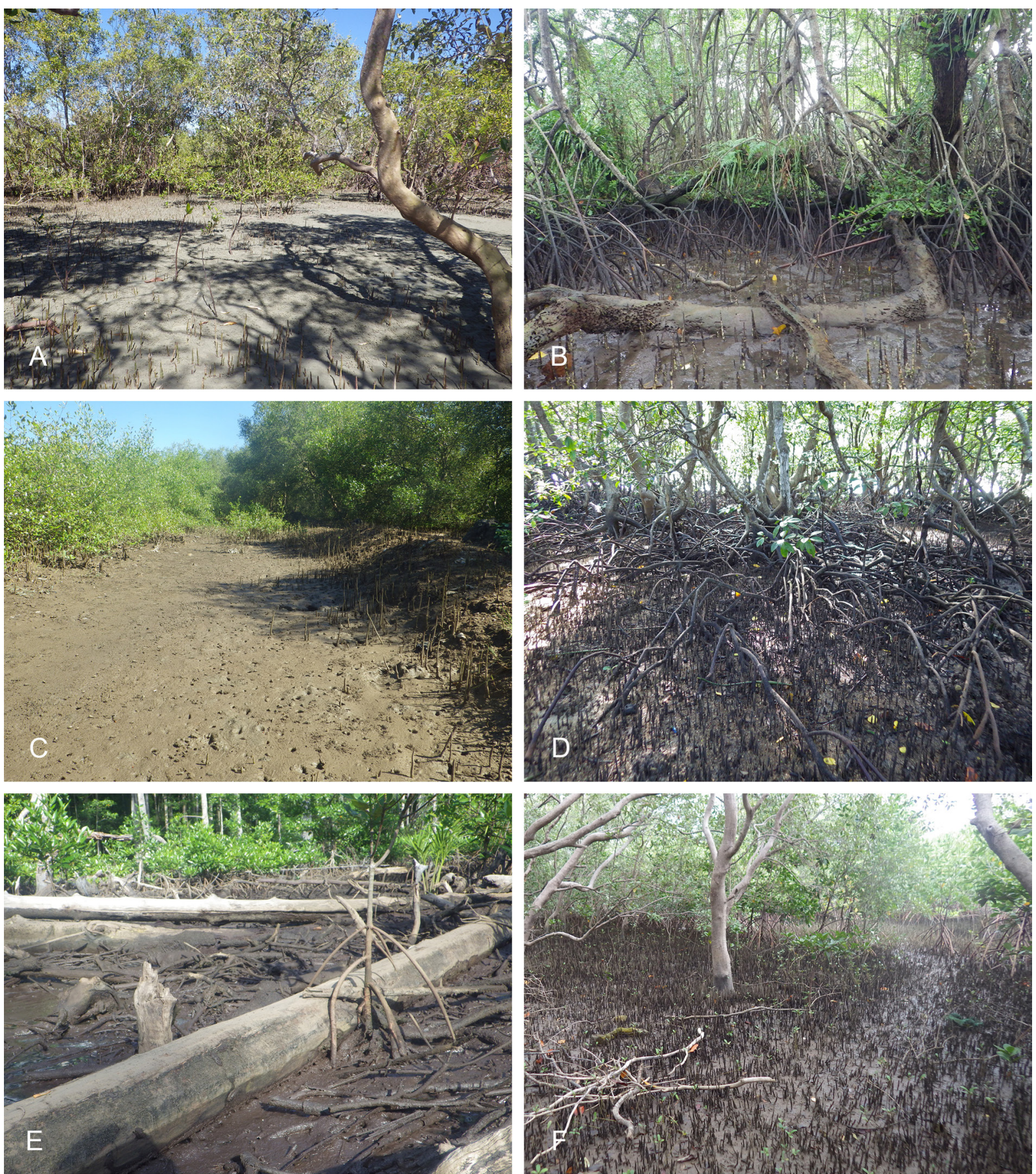

Fig. 24. Paromoionchis tumidus (Semper, 1880) comb. nov. unit \#1, habitats. A. Australia, Queensland, mangrove by creek with Rhizophora and Avicennia (station 119). B. Indonesia, Ambon, mangrove with large Rhizophora and some open spaces between trees (station 131). C. Indonesia, Lombok, mudflat at the margin of mangrove (station 145). D. Philippines, Bohol, narrow forest on the edge of fish ponds, with tall Rhizophora and Avicennia trees, and different types of mud (station 194). E. Indonesia, Halmahera, logged area by an old Rhizophora forest (station 212). F. Vietnam, Nha Trang, mostly Avicennia trees, mud not deep (station 239). 
gland; the penial retractor muscle inserts to the body wall near the heart; the penis bears tiny hooks which are identical to the hooks of the species described here (Fig. 21C).

The type material of $O$. hongkongense is anatomically identical to the species described here and it is characterized by the exact same combination of characters: no rectal gland, intestinal loops of type II (Fig. 12D), an accessory penial gland, a retractor muscle inserting near the heart, a male opening between the two eye tentacles and a penis with tiny hooks (which Britton illustrated and measured as $<20 \mu \mathrm{m})$.

Strictly speaking, Onchidium samarense probably should be regarded as a nomen dubium because 1) the jar with the type material includes three specimens while Semper only mentioned two specimens in the original description, 2) the male organs of two of the syntypes are gone (possibly dissected by Semper) and cannot be checked, and 3) important features (e.g., the insertion of the retractor muscle) are not mentioned in the original description. However, our observations are compatible with the original description and it is possible that all three specimens were actually identified as $O$. samarense by Semper himself. According to Semper (1882: 269, our translation), the penis of $O$. samarense is "very similar to that of $O$. tumidum." Indeed, the male apparatus of the lectotype is very similar to that of the species described here. In particular, the retractor muscle of the penis (not described by Semper) is thin but reaches the heart, following some nerves, as in the species described here. Semper described no
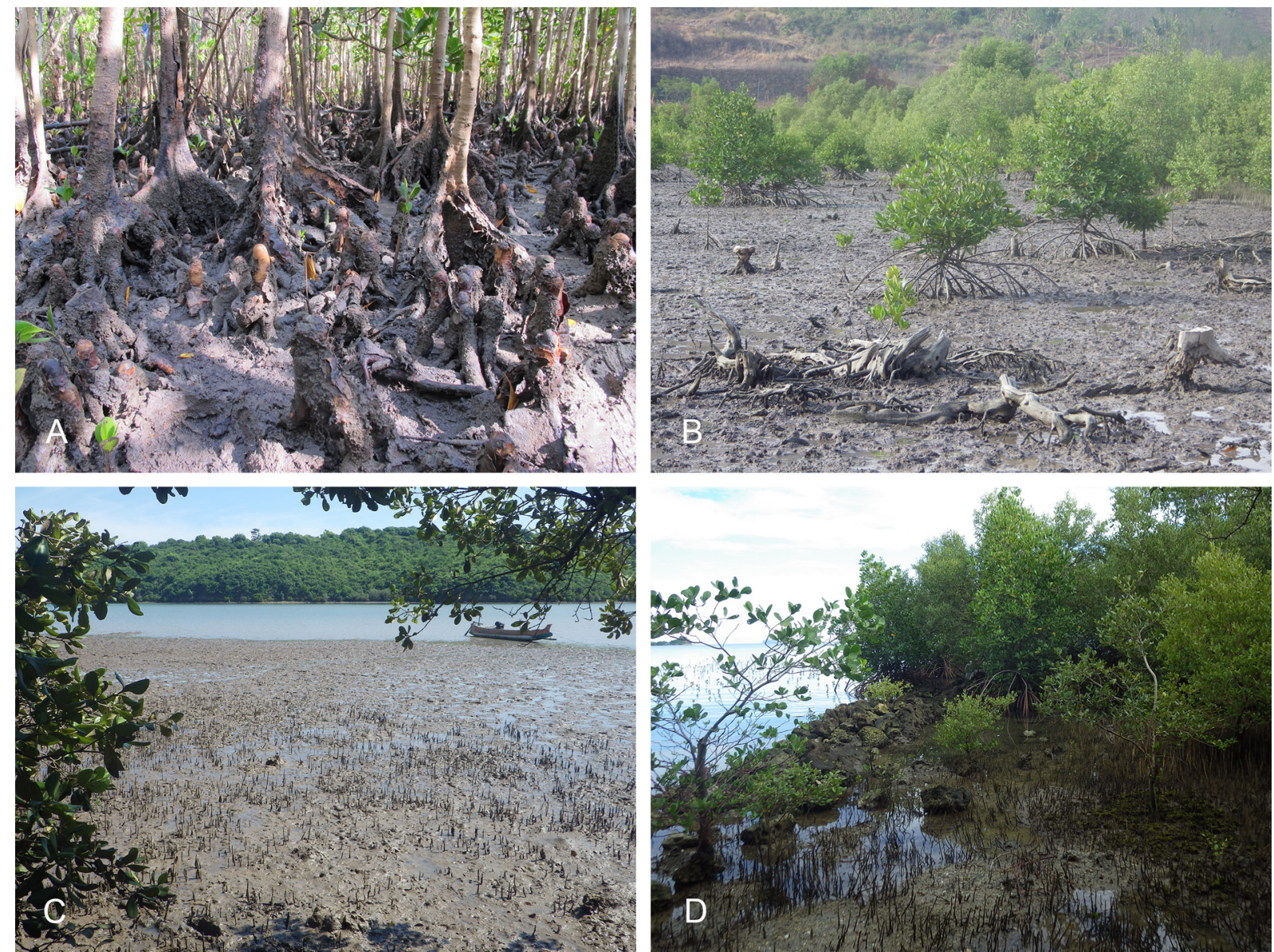

Fig. 25. Paromoionchis tumidus (Semper, 1880) comb. nov. unit \#2, habitats. A. Australia, Northern Territory, large mangrove of Sonneratia, Rhizophora and Ceriops (st. 66). B. Indonesia, Sumatra, small patch of mangrove, very impacted (st. 81). C. Indonesia, Lombok, open Avicennia mangrove (station 146). D. Philippines, Luzon, narrow and very sandy Avicennia mangrove, with no mud (st. 179). 
'cartilaginous teeth.' However, that can be easily explained by the fact that the hooks inside the penis of $O$. tumidum are soft and tiny $(<20 \mu \mathrm{m})$ and, unlike the large and solid hooks found in some other onchidiids, can hardly be seen under a light microscope (in fact, because there are not many hooks, they are hard to find even with SEM). Our collections currently do not include any specimen from Samar, the type locality of $O$. samarense, but we did collect many species of onchidiids in Luzon, just next to Samar, as well as in Bohol, a bit further south in the Philippines. Given the anatomy of $O$. samarense (no rectal gland, digestive system of type II, male opening clearly on the left of the right eye tentacle, accessory penial gland and retractor muscle inserting near the heart), it is most likely that $O$. samarense applies to the same species as $O$. tumidum. Because its nomenclatural status still remains problematic (it could be regarded as a nomen dubium) and because its written description was published in 1882 and not in $1880, O$. samarense is regarded as a junior synonym of $O$. tumidum.

Plate (1893) identified five specimens from Ponape (now Pohnpei, Micronesia) and one specimen from Singapore as Onchidium tumidum. Given that their intestinal loops were of type I, the specimens from Ponape were misidentified. It is impossible to determine whether the specimen from Singapore (with intestinal loops of type II) actually belongs to P. tumidus. Bretnall (1919) listed previous records but did not examine any new material. Bretnall also suggested that Onchidium punctatum Quoy \& Gaimard, 1832 could possibly refer to the same species as $O$. tumidum. However, O. punctatum clearly belongs to the genus Peronia. In fact, it was transferred to Scaphis Labbé, 1934 by Labbé (1934a: 203) as Scaphis punctata and Scaphis is a junior synonym of Peronia. Hoffmann (1928) mentioned O. tumidum, $O$. samarense and $O$. mertoni but did not examine any new material. Hoffmann also suggested that the record of Onchidium tabularis (Tapparone-Canefri, 1883), listed by Boettger (1923) from the Aru and Kei Islands, was a misidentification for O. mertoni (Boettger provided a record but did not describe any specimens). However, Hoffmann's claim cannot be checked because the application of Onchidella tabularis Tapparone-Canefri, 1883 (as Oncidiella) is very unclear (the type material could not be located and the original description is not informative).

Three onchidiid sequences from mainland China were obtained from GenBank, the only ones that are not new in our data set (Table 1). These sequences were misidentified as Paraoncidium reevesii (J.E. Gray, 1850). Paraoncidium Labbé, 1934 is not a valid name: it is a junior synonym of Onchidina Semper, 1882. Also, Onchidium reevesi (J.E. Gray, 1850) is actually one of the three valid species of Onchidium (Dayrat et al. 2016).

Paromoionchis daemelii (Semper, 1880) comb. nov. Figs 26-30

Onchidium dämelii Semper, 1880: pl. 20, fig. 2.

Onchidium dämelii - Semper 1882: 270-271, pl. 21, fig. 9.

\section{Material examined}

Type material

AUSTRALIA • lectotype (here designated; 17/14 mm); New South Wales, Sydney; ZMB 31640a • 1 paralectotype $(17 / 17 \mathrm{~mm}$ ); same locality as lectotype; ZMB $31640 \mathrm{~b} \cdot 1$ paralectotype (destroyed, dried); same locality as lectotype; ZMB $39035 \bullet 2$ paralectotypes (?); same locality as lectotype; ZMH $27476 / 2$.

\section{Notes on type material}

The lectotype, 17/14 mm, is designated here (ZMB 31640a). All other syntypes become paralectotypes. According to the original description, the type material included only three specimens. However, five possible syntypes could be located in museum collections, all from Sydney, Australia: 2 specimens, 
one of which, dissected with male parts remaining inside $(17 / 14 \mathrm{~mm})$, is designated as lectotype (ZMB $31640 \mathrm{a})$ and the other one, still entire $(17 / 17 \mathrm{~mm}$ ), is a paralectotype (ZMB 31640b); 1 specimen destroyed, in pieces and completely dried (ZMB 39035); and 2 specimens (ZMH 27476/2), both entire. It is unclear exactly which specimens Semper used for the description, but it is safe to assume that the anatomical details he provided are based on the only two dissected specimens. Two species of Paromoionchis gen. nov. are present in Sydney, P. tumidus and the species described here, which are cryptic externally but distinct internally. Thus, the specimens that were not dissected by Semper could belong either to P. tumidus or to the species treated here. Hence the necessity of designating a lectotype in order to clarify the application of the name Onchidium daemelii.

\section{Other material}

AUSTRALIA - New South Wales - 1 spec. (37/25 [1511] mm); Sydney, Middle Harbour, N of

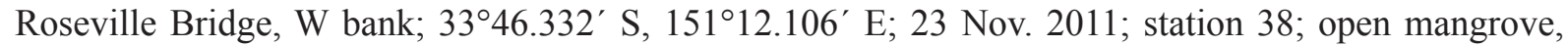
in old logs on the mud; AM C.468910.001 • 1 spec. $(17 / 10$ [1510] mm); same data as for preceding;
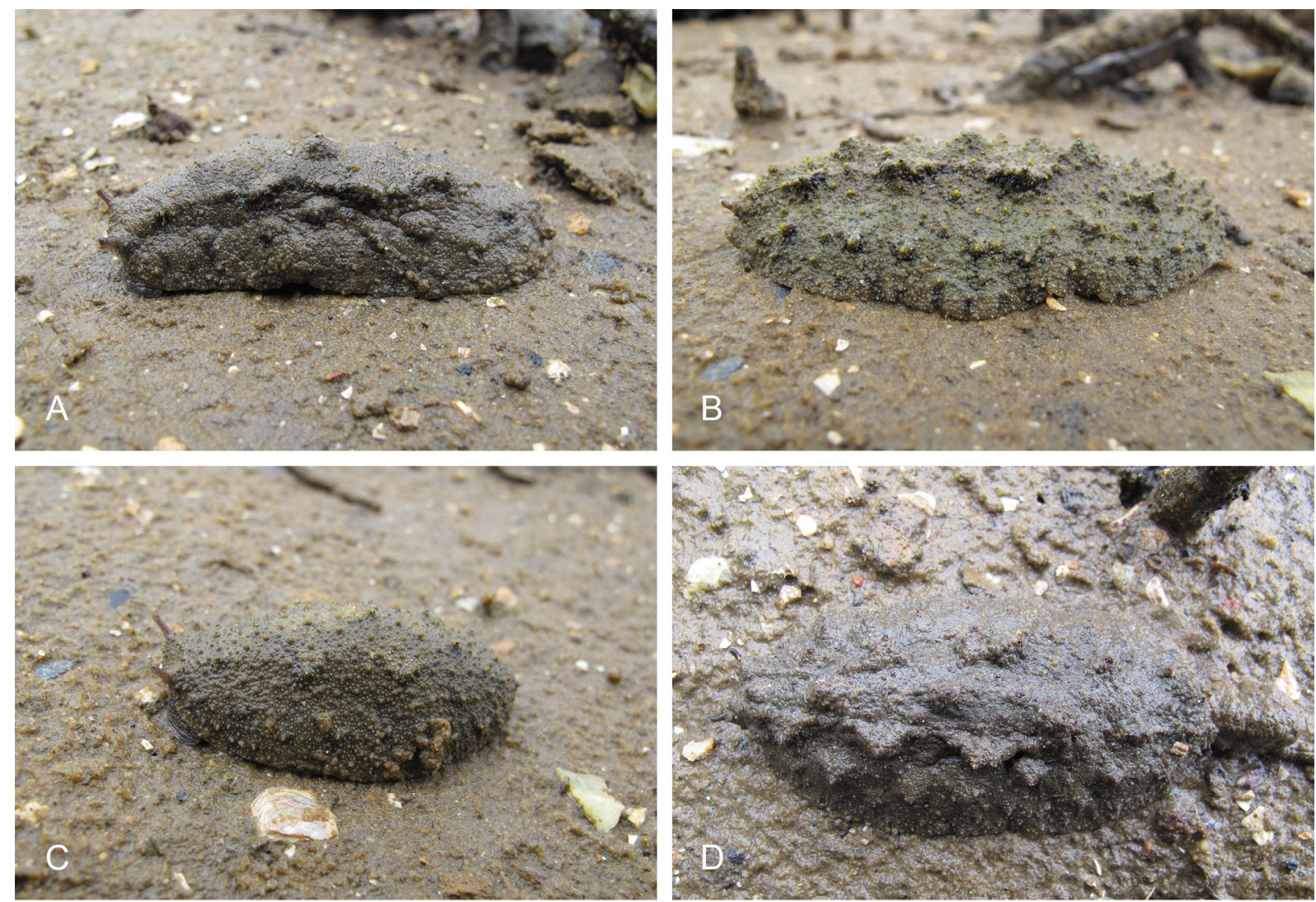

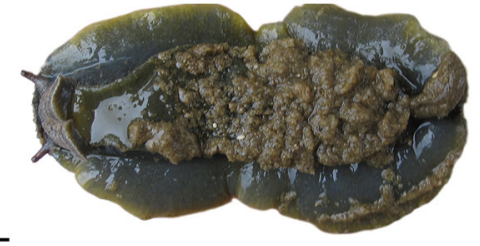

E

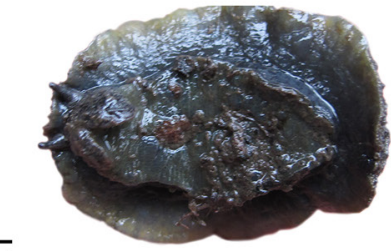

$\mathrm{F}$

Fig. 26. Paromoionchis daemelii (Semper, 1880) comb. nov., live animals, Australia, New South Wales. A. Dorsal view, $51 \mathrm{~mm}$ long [1514] (AM C.468912.002). B. Dorsal view, $56 \mathrm{~mm}$ long [1519] (AM C.468917.001). C. Dorsal view, $31 \mathrm{~mm}$ long [1515] (AM C.468914.001). D. Dorsal view, $62 \mathrm{~mm}$ long [1518] (AM C.468913.001). E. Ventral view, $42 \mathrm{~mm}$ long [1512] (AM C.468912.003). F. Ventral view, $36 \mathrm{~mm}$ long [1511] (AM C.468910.001). G. Ventral view, same as C. 
AM C.468911.001 • 1 spec. (65/35 [1518] mm); Sydney, Pittwater, Church Point, next to yacht club; $33^{\circ} 39.107^{\prime} \mathrm{S}, 151^{\circ} 17.363^{\prime} \mathrm{E}$; 24 Nov. 2011; station 39; muddy sand next to small patch of mangrove and rocks on sandy beach; AM C.468913.001 • 1 spec. $(60 / 35$ [1519] mm); same data as for preceding; AM C.468917.001 • 1 spec. (28/18 [1515] mm); same data as for preceding; AM C.468914.001 •
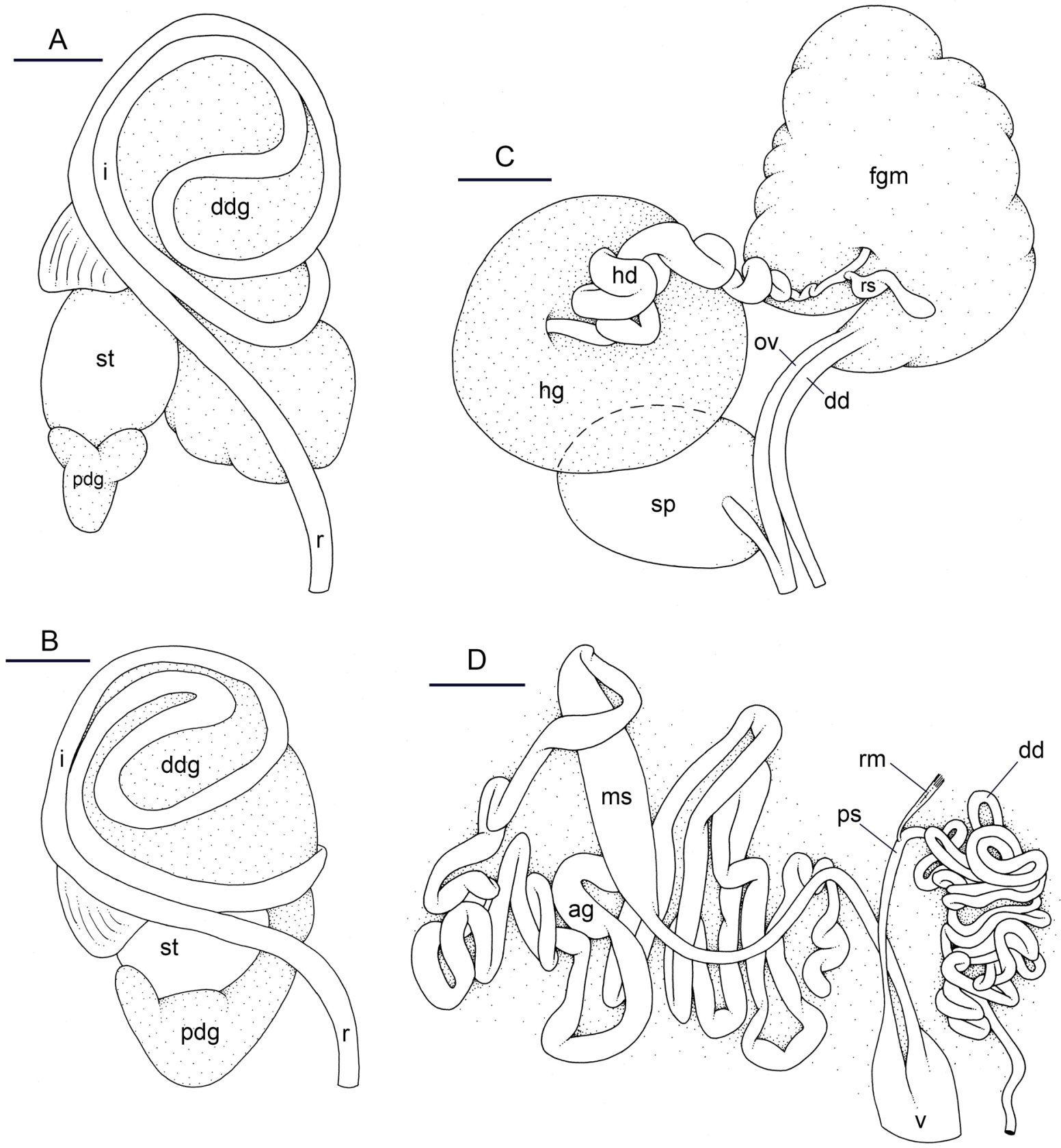

Fig. 27. Paromoionchis daemelii (Semper, 1880) comb. nov. A. Digestive system, Australia, New South Wales [1519] (AM C.468917.001). B. Digestive system, lectotype of Onchidium daemelii (ZMB 31640a). C. Posterior hermaphroditic (female) reproductive system, same as A. D. Male copulatory organs, same as A. Abbreviations: ag = accessory penial gland; $\mathrm{dd}=$ deferent duct; $\mathrm{ddg}=$ dorsal lobe of digestive gland; fgm = female gland mass; hd = hermaphroditic duct; $\mathrm{hg}=$ hermaphroditic gland; $\mathrm{i}$ = intestine; $\mathrm{ms}=$ muscular sac (of accessory penial gland); ov = oviduct; $\mathrm{pdg}=$ posterior lobe of digestive gland; $\mathrm{ps}=$ penial sheath; $\mathrm{r}=$ rectum; $\mathrm{rm}=$ retractor muscle; $\mathrm{rs}=$ receptaculum seminis; $\mathrm{sp}=$ spermatheca; $\mathrm{st}=$ stomach; $\mathrm{v}=$ vestibule. Scales: $\mathrm{A}=4 \mathrm{~mm} ; \mathrm{B}-\mathrm{D}=3 \mathrm{~mm}$. 
1 spec. (52/28 [1514] mm); same data as for preceding; AM C.468912.002 1 spec. (40/20 [1512] mm); same data as for preceding; AM C.468912.003 1 spec. (50/25 [1521] mm); Sydney, Pittwater, Careel Bay; 3337.323' S, $151^{\circ} 19.878^{\prime}$ E; 24 Nov. 2011; station 40; supratidal zone on the margin of salt marsh, mangrove patch on side of creek; AM C.468919.001. - Queensland - 2 spec. (15/12 [1532] and 8/6 [1533] mm); Thirsty Sound, Plum Tree, beach in front of Endeavour Park; $22^{\circ} 08.144^{\prime} \mathrm{S}, 150^{\circ} 01.856^{\prime} \mathrm{E}$; 14 Sep. 2002; I. Loch, D.L. Beechey and A.C. Miller leg.; sheltered, muddy cobble shore; AM C.415270 - 1 spec. (8/6 [2668] mm); Bowen, Doughty Creek; 2001.478’ S, 148¹4.224' E; 3 Jul. 2013; station 119; mangrove of Rhizophora and Avicennia on one side of creek; MTQ.

\section{Color and morphology of live animals (Fig. 26)}

Live animals are often covered with mud, in which case their dorsal color can hardly be seen. The background of the dorsal notum is brown, occasionally mottled with darker or lighter areas. In addition, in some animals, the tip of dorsal papillae (with and without dorsal eyes) can be bright yellow. The foot is gray. The hyponotum is gray (same color as the foot), yellow, or both (yellow outer ring and gray inner ring). The color of the foot and of the hyponotum of an individual can change rapidly, especially when disturbed. The ocular tentacles are gray or brown, and may or may not be speckled with white dots, like the head. The ocular tentacles are short (just a few millimeters long).

Digestive system (Figs 27A-B, 28)

Radulae measure up to $5.4 \mathrm{~mm}$ in length. Examples of radular formulae are presented in Table 4.
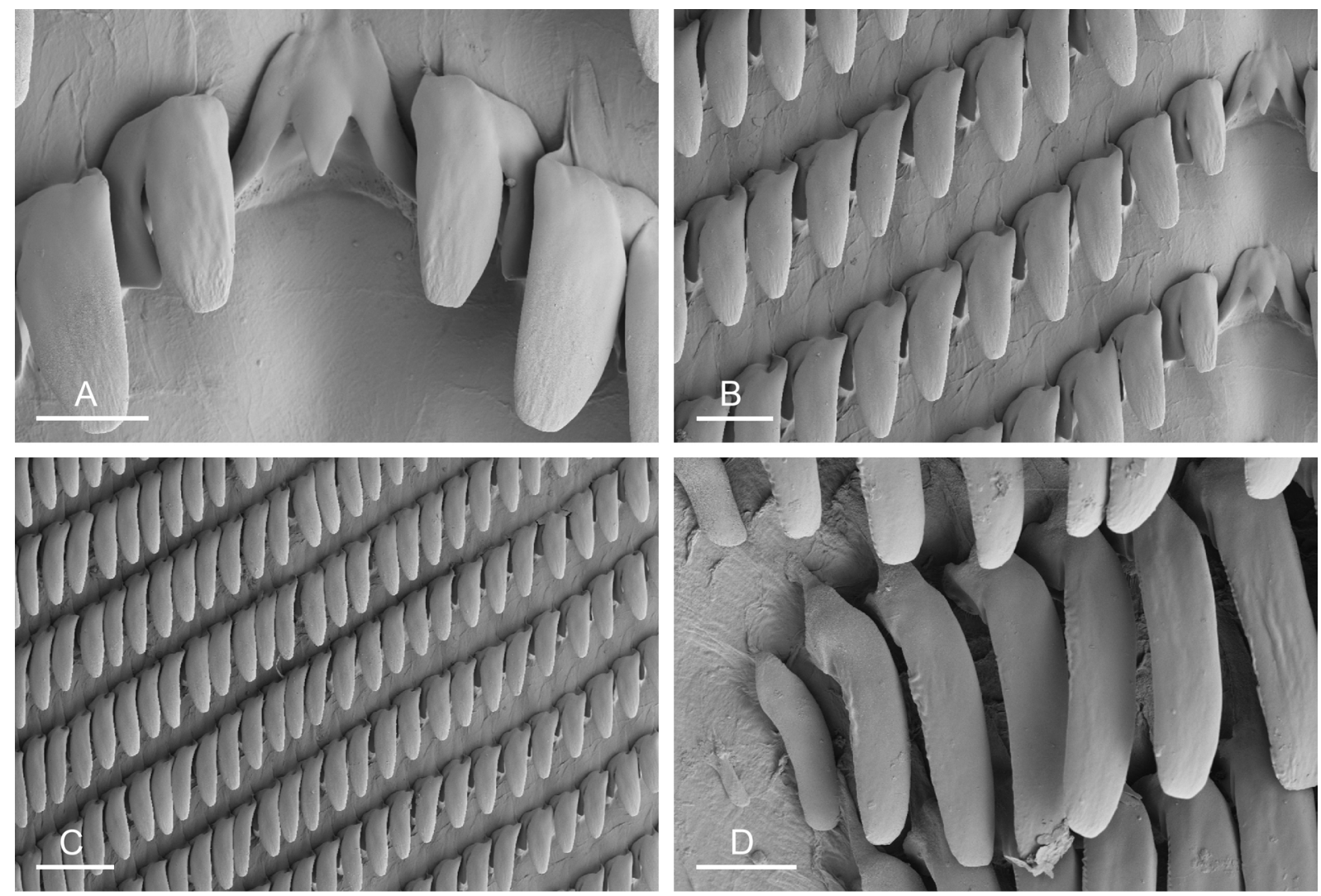

Fig. 28. Paromoionchis daemelii (Semper, 1880) comb. nov., radula, Australia, New South Wales [1519] (AM C.468917.001). A. Rachidian and innermost lateral teeth. B. Lateral teeth with rachidian teeth. C. Lateral teeth. D. Outermost lateral teeth. Scales: A, D $=20 \mu \mathrm{m} ; \mathrm{B}-\mathrm{C}=30 \mu \mathrm{m}$. 


\section{Reproductive system (Figs 27C-D, 29)}

The male anterior organs consist of the penial complex (penis, penial sheath, vestibule, deferent duct, retractor muscle) and the accessory penial gland (flagellum and hollow spine). The hollow spine of the accessory penial gland is narrow, elongated, slightly curved. Its base is conical. Its diameter is approximately $80 \mu \mathrm{m}$ for most of its length, except at its base $(200 \mu \mathrm{m})$ and tip $(60 \mu \mathrm{m})$. Its length ranges from $2.5 \mathrm{~mm}$ ([1519] AM C.468917.001) to $2.7 \mathrm{~mm}$ ([1521] AM C.468919.001), and its shape does vary between individuals (Fig. 29). The penial sheath is narrow and elongated. The retractor muscle is short (shorter than the penial sheath) or even vestigial (its distal end being free in the visceral cavity, with no clear insertion). The deferent duct is highly convoluted, with many loops. Inside the penial sheath, the penis is a narrow, elongated, soft, hollow tube of approximately $100 \mu \mathrm{m}$ in diameter; internally, the penis bears a few smooth (no hooks) longitudinal ridges.

\section{Distinctive diagnostic features}

Externally, Paromoionchis daemelii cannot be distinguished from other species of Paromoionchis gen. nov. (Table 3). Also, its internal anatomy (accessory penial gland, vestigial penial retractor muscle, smooth penis) is very similar to that of $P$. boholensis gen. et sp. nov. The distribution range of $P$. daemelii overlaps with that of only one species of Paromoionchis gen. nov., P. tumidus (Fig. 6). Both species live in similar habitats and can even be found at the same station. They can only be distinguished internally thanks to a few anatomical details: in $P$. daemelii, the penis is smooth and the penial retractor muscle is very short or even vestigial, while in $P$. tumidus the penis bears some tiny hooks and the penial retractor muscle inserts near the heart (Table 3 ).
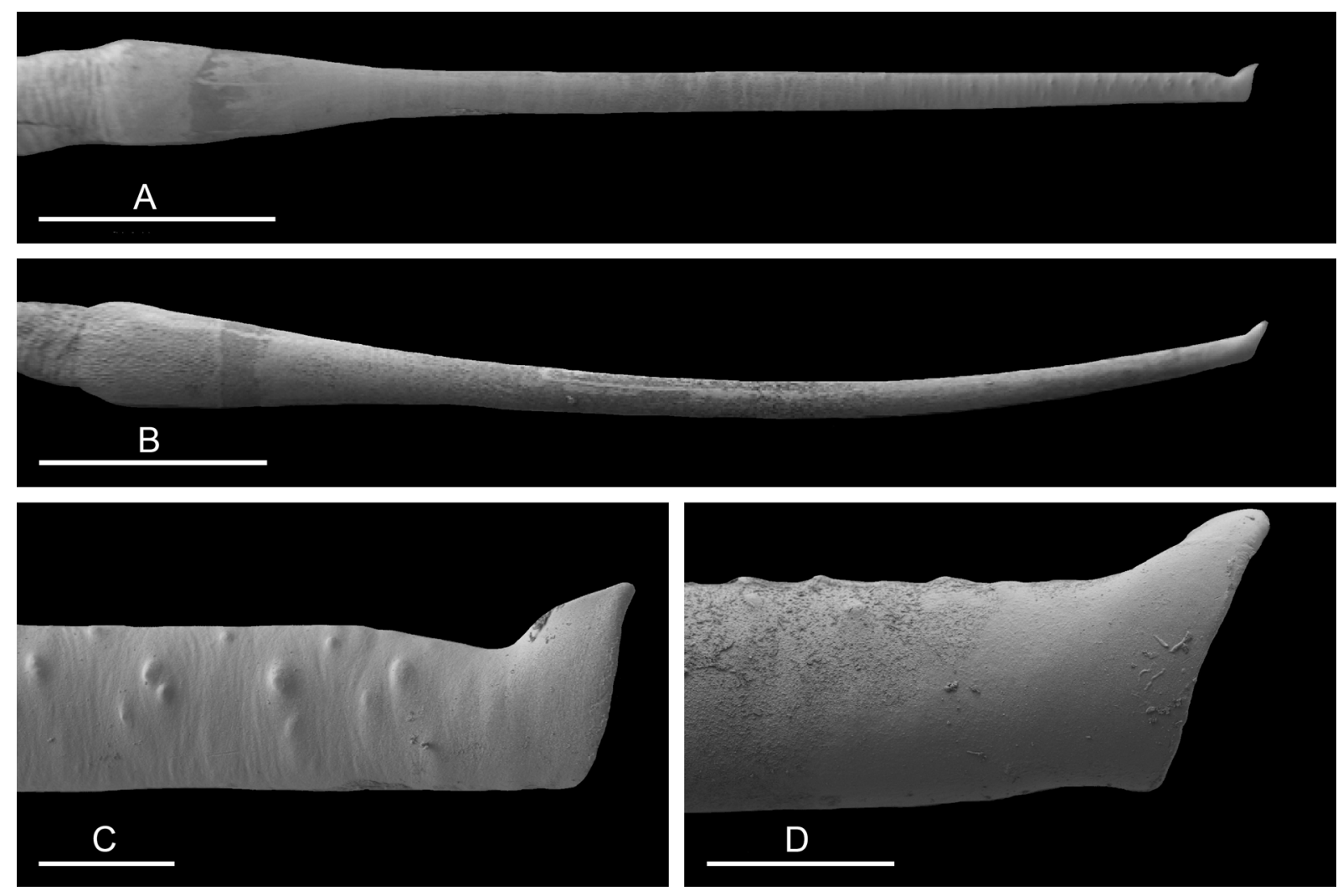

Fig. 29. Paromoionchis daemelii (Semper, 1880) comb. nov., spine of accessory penial gland. A. Australia, New South Wales [1519] (AM C.468917.001). B. Australia, New South Wales [1521] (AM C.468919.001). C. Distal tip of spine, same as A. D. Distal tip of spine, same as B. Scales: $\mathrm{A}-\mathrm{B}=500 \mu \mathrm{m} ; \mathrm{C}-\mathrm{D}=50 \mu \mathrm{m}$. 
DAYRAT B. et al., A new genus of mangrove onchidiid slugs

\section{Distribution (Fig. 6)}

Australia: New South Wales (type locality, present study), Queensland (present study).

\section{Habitat (Fig. 30)}

Paromoionchis daemelii is found on mud or muddy logs, inside or near mangroves, or on muddy sand. It is not common in central Queensland or New South Wales, but its abundance in southern Queensland is unknown.

\section{Remarks}

The publication dates of the various sections of the volume on Landmollusken by Carl Semper in the Reisen im Archipel der Philippinen series were clarified by Johnson (1969). The species name Onchidium daemelii was first published by Semper in 1880 with one figure (pl. 20, fig. 2) but no written description. Because Onchidium daemelii was published before 1931, ICZN Article 12.2.7 applies and the name is available (Semper's figures are regarded as an indication accompanying the name Onchidium daemelii). Also, the specific name was originally spelled dämelii. However, according to ICZN Article 32.5.2.1., the correct spelling is daemelii. Both daemelii (e.g., Labbé 1934a) and damelii (e.g., Kenny \& Smith 1987, 1988) are spelling mistakes.

According to our current data, there are only two species of Paromoionchis gen. nov. in New South Wales (Fig. 6): P. tumidus and P. daemelii. They cannot be distinguished externally but they differ anatomically (Table 3). Both species are characterized by the lack of a rectal gland, a digestive system of type II, a male opening clearly to the left of the right eye tentacle (Semper described a male opening under the right eye tentacle, but it is distinctly below and left of it) and an accessory penial gland. The retractor muscle of the penis of $O$. daemelii, described as "very thin" by Semper, is vestigial in the lectotype, whereas the retractor muscle of P. tumidus is not vestigial and inserts near the heart. No "teeth" (the term he used to refer to penial hooks) are mentioned by Semper in the original description of $O$. daemelii, while the penis of $P$. tumidus bears some hooks. Therefore, the combination of characters found in the lectotype of $O$. daemelii and in Semper's original description (retractor muscle vestigial and soft penis with no hooks) is only compatible with the species described here, not with P. tumidus, which justifies the present application of $P$. daemelii.
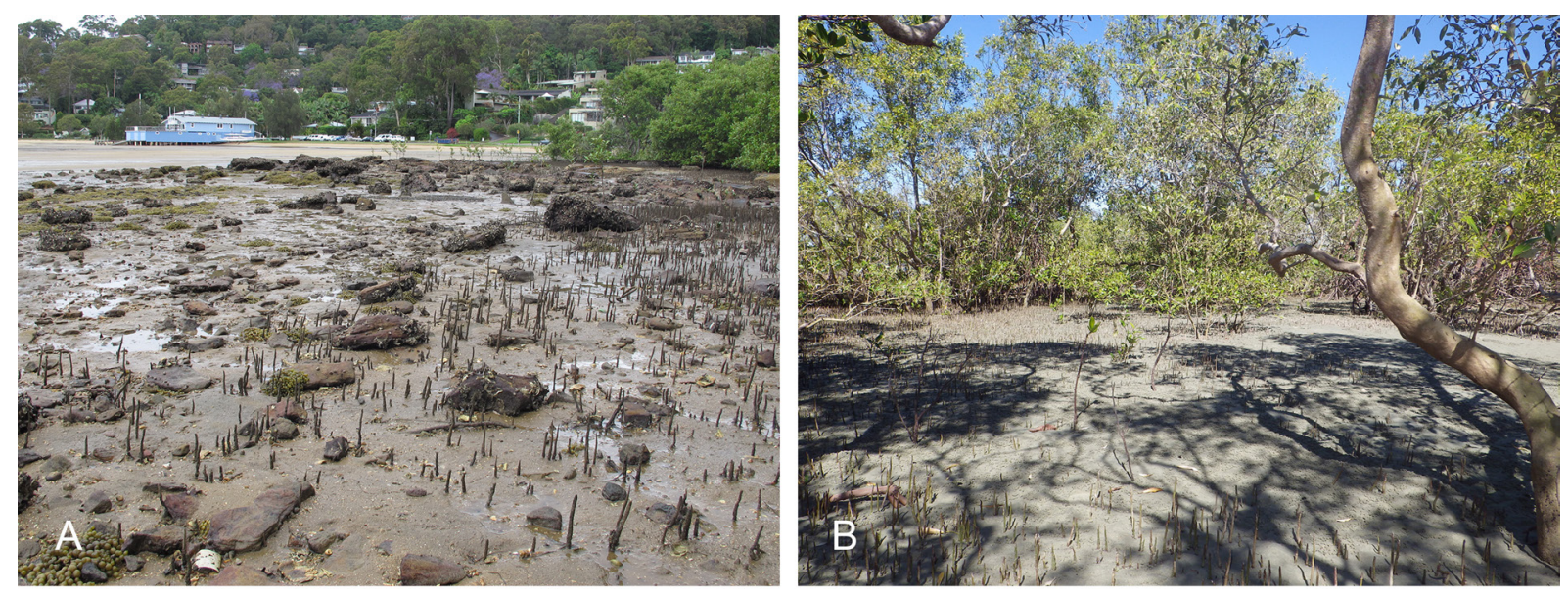

Fig. 30. Paromoionchis daemelii (Semper, 1880) comb. nov., habitats. A. Australia, New South Wales, muddy sand next to small patch of mangrove and rocks on sandy beach (station 39). B. Australia, Queensland, Rhizophora and Avicennia mangrove (station 119). 
Onchidium daemelii was recorded from New South Wales (Lendenfeld 1886; Tenison-Woods 1888) and even New Guinea (Tapparone-Canefri 1883) but it is not possible to determine whether it was identified properly without re-examining the material which these authors examined (which may or may not have been deposited). Bretnall (1919), Hoffmann (1928) and Labbé (1934a) mentioned Onchidium daemelii without adding any new material. Finally, Kenny \& Smith (1987) published an ecological study on a species they identified as Onchidium damelii in a mangrove on Magnetic Island, Queensland. However, given that $P$. daemelii is rare in northern and central Queensland and that its identification requires detailed study of the internal anatomy, Kenny \& Smith likely studied $P$. tumidus rather than $P$. daemelii (or a mix of both species).

Paromoionchis boholensis Dayrat \& Goulding gen. et sp. nov. urn:Isid:zoobank.org:act:104C35EF-FBF9-4EC2-A5A8-89AC30009270

Figs $31-40$

\section{Etymology}

Paromoionchis boholensis gen. et sp. nov. is named after Bohol Island, where the type locality is.

\section{Material examined}

Holotype

PHILIPPINES • holotype (28/18 [3288] mm); Bohol, Maribojoc; 0943.645’ N, 12350.988' E; 15 Jul. 2014; station 193; small island at end of boardwalk, sandy mud and rocks in back of mangrove; PNM 041266.

\section{Other material}

INDONESIA-Sulawesi • 2 spec. $\left(35 / 22\right.$ [2128] and 37/20[2129] mm); Wori; 01 $36.055^{\prime} \mathrm{N}, 124^{\circ} 51.730^{\prime} \mathrm{E}$; 9 Mar. 2013; station 84; tall mangrove forest of Sonneratia and Avicennia, with old logs; UMIZ 00141

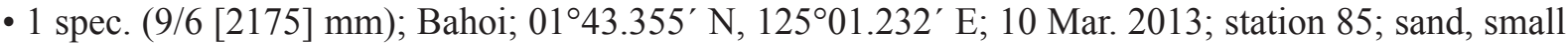
rocks and pieces of wood, near narrow coastal mangrove; UMIZ $00142 \cdot 1$ spec. (20/13 [2199] mm); Tamperong; $01^{\circ} 41.513^{\prime} \mathrm{N}, 125^{\circ} 00.797^{\prime} \mathrm{E}$; 12 Mar. 2013; station 87; muddy mangrove with small and dense Rhizophora; UMIZ 00143 • 1 spec. (12/8 [2316] mm); Mantehang; $01^{\circ} 41.880^{\prime} \mathrm{N}, 124^{\circ} 46.741^{\prime} \mathrm{E}$; 15 Mar. 2013; station 91; Sonneratia at low intertidal and Rhizophora at high intertidal; UMIZ 00144 - 1 spec. (20/13 [2360] mm); Panikkiang Island; 04²1.730’ S, 119³5.630’ E; 25 Mar. 2013; station 94; Rhizophora, Avicennia, Sonneratia and old logs; UMIZ 00145. - Ambon - 3 spec. (40/25 [2849],

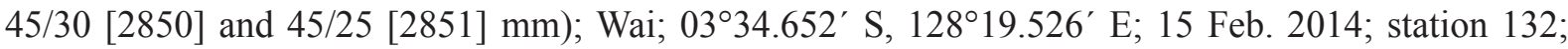
narrow band of old Avicennia trees on sandy mud, old logs on ground; UMIZ 00146. - Seram - 1 spec. (45/28 [2884] mm); Piru; 030.04.072' S, $128^{\circ} 11.362^{\prime}$ E; 19 Feb. 2014; station 136; Sonneratia mangrove next to fish market, next to beach of palms and ferns, with cattle roaming around; UMIZ 00147. - Kei Islands • 2 spec. (10/8 [2896] and 17/8 [2901] mm); Un; 05 38.273' S, 132 ${ }^{\circ} 45.738^{\prime} \mathrm{E} ; 23$ Feb. 2014; station 137; Bruguiera and Rhizophora, some muddy areas and some with coral rubble; UMIZ 00148 - 2 spec. (15/10 [2903] and 18/8 [2911] mm); Un; 05³8.273' S, 132 45.738' E; 25 Feb. 2014; station 140; back of mangrove, on rocks, on mud, inside logs and under leaf litter; UMIZ 00149 - 3 spec. (40/22 [3565], 30/20 [2935] and 40/22 [2937] mm); Fiditan; 05³5.957' S, 132 45.112' E; 28 Feb. 2014; station 144; rocks behind muddy Rhizophora mangrove; UMIZ 00150. - Bali • 1 spec. (35/17 [3117] mm); Gilimanuk; 08¹0.156’ S, 114²6.652' E; 4 Apr. 2014; station 156; muddy mangrove with Rhizophora and Avicennia trees; UMIZ 00140. - Halmahera • 1 spec. (25/16 [5019] mm); Sofifi; $00^{\circ} 45.473^{\prime}$ N, $127^{\circ} 35.897^{\prime}$ E; 8 Mar. 2015; station 205; Sonneratia mangrove, with dense roots and hard mud; UMIZ 00151 - 2 spec. (47/30 [5140] and 35/22 [5146] mm); Gamkonora; 01 ${ }^{\circ} 26.911^{\prime} \mathrm{N}$, $127^{\circ} 31.625^{\prime}$ E; 21 Mar. 2015; station 219; mostly Rhizophora mangrove with some sandy areas and some open muddy spaces; UMIZ 00152. 

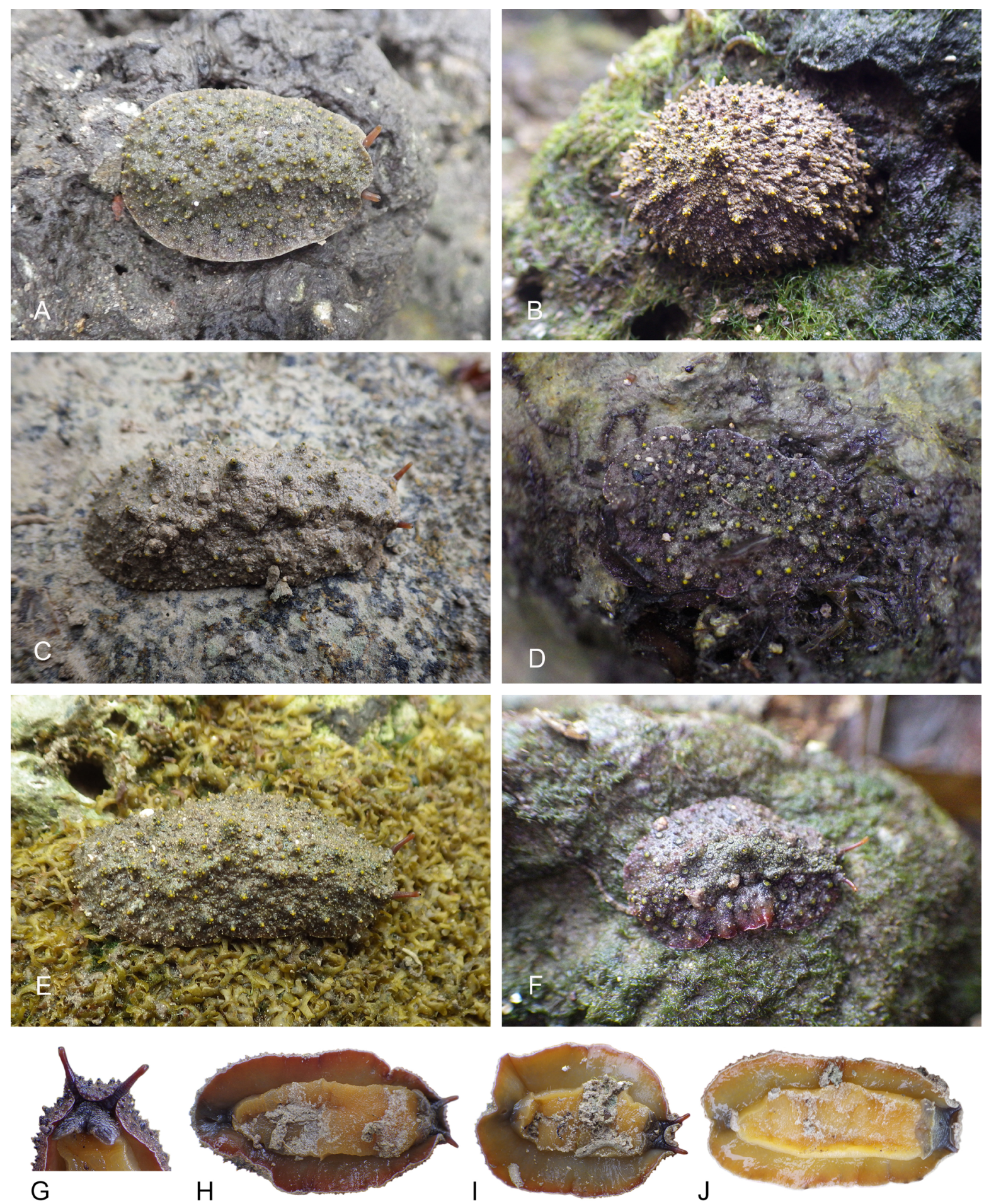

Fig. 31. Paromoionchis boholensis gen. et sp. nov., unit \#1, live animals. A. Holotype, dorsal view, $28 \mathrm{~mm}$ long [3288], Philippines, Bohol (PNM 041266). B. Dorsal view, $26 \mathrm{~mm}$ long [3609], Philippines, Luzon (PNM 041267). C. Dorsal view, $38 \mathrm{~mm}$ long [3417], Philippines, Bohol (PNM 041270). D. Dorsal view, $17 \mathrm{~mm}$ long [3283], Philippines, Bohol (PNM 041268). E. Dorsal view, $30 \mathrm{~mm}$ long [3372], Philippines, Bohol (PNM 041269). F. Dorsal view, $17 \mathrm{~mm}$ long [3619], Philippines, Bohol (PNM 041268). G. Ventral view, same as E. H. Ventral view, $38 \mathrm{~mm}$ long [3422], Philippines, Bohol (PNM 041270). I. Ventral view, $32 \mathrm{~mm}$ long [3413], Philippines, Bohol (PNM 041270). J. Ventral view, same as $\mathrm{C}$. 

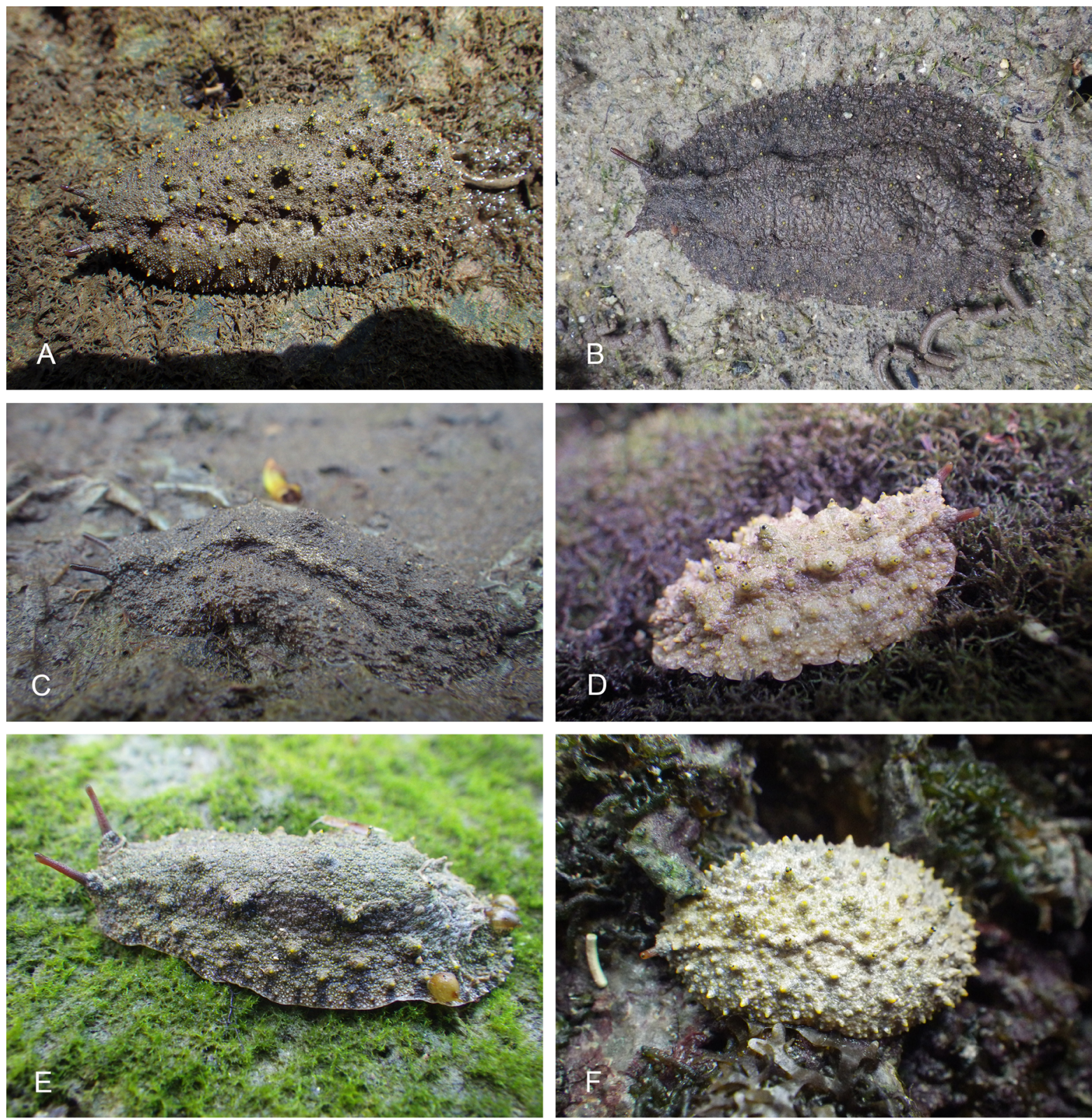

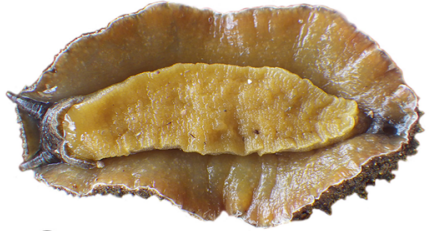

G

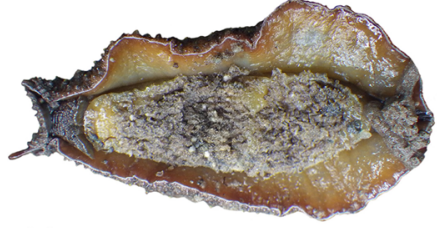

$\mathrm{H}$

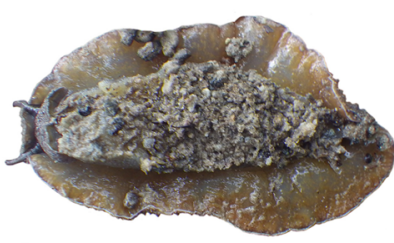

I

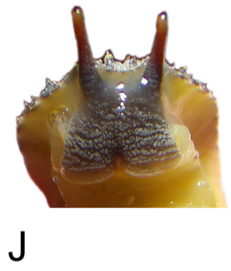

$\mathrm{J}$

Fig. 32. Paromoionchis boholensis gen. et sp. nov., unit \#2, live animals. A. Dorsal view, $37 \mathrm{~mm}$ long [2129], Indonesia, Sulawesi (UMIZ 00141). B. Dorsal view, $45 \mathrm{~mm}$ long [2851], Indonesia, Ambon (UMIZ 00146). C. Dorsal view, 35 mm long [3117], Indonesia, Bali (UMIZ 00140). D. Dorsal view, $18 \mathrm{~mm}$ long [2911], Indonesia, Kei (UMIZ 00149). E. Dorsal view, $40 \mathrm{~mm}$ long [2937], Indonesia, Kei (UMIZ 00150). F. Dorsal view, 15 mm long [2903], Indonesia, Kei (UMIZ 00149). G. Ventral view, $45 \mathrm{~mm}$ long [2884], Indonesia, Seram (UMIZ 00147). H. Ventral view, same as B. I. Ventral view, $45 \mathrm{~mm}$ long [2850], Indonesia, Ambon (UMIZ 00146). J. Frontal view, $17 \mathrm{~mm}$ long [2901], Indonesia, Kei (UMIZ 00148). 
PHILIPPINES - Luzon • 1 spec. (25/18 [3609] mm); Lian, Batangas; 1358.130’ N, 120³7.471' E; 5 Jul. 2014; station 179; narrow and impacted mangrove of Avicennia near village, very sandy, little to no mud; PNM 041267. - Bohol • 2 spec. (16/9 [3283] and 17/10 [3619] mm); same data as for holotype; PNM 041268 - 3 spec. (20/15 [3369], 35/18 [3372] and 27/20 [3411] mm); Mabini; 09 51.586' N, $124^{\circ} 34.155^{\prime}$ E; 18 Jul. 2014; station 196; open Avicennia and Sonneratia forest with sand, algae and coral rubble; PNM 041269 • 5 spec. (30/22 [3412], 30/23 [3413], 40/17 [3417], 40/20 [3422] and 42/25 [3423] mm); Maribojoc; $09^{\circ} 44.280^{\prime} \mathrm{N}, 1^{2} 3^{\circ} 49.389^{\prime} \mathrm{E}$; 20 Jul. 2014; station 202; uplifted coral rubble with sand and algae, near Sonneratia trees; PNM 041270.

\section{Color and morphology of live animals (Figs 31-32)}

Live animals are often covered with mud, in which case their dorsal color can hardly be seen. In unit \#1, the background of the dorsal notum is brown, occasionally mottled with darker or lighter areas, while in unit \#2 it ranges from very light brown (almost white) to dark brown, mottled or not. In some animals,
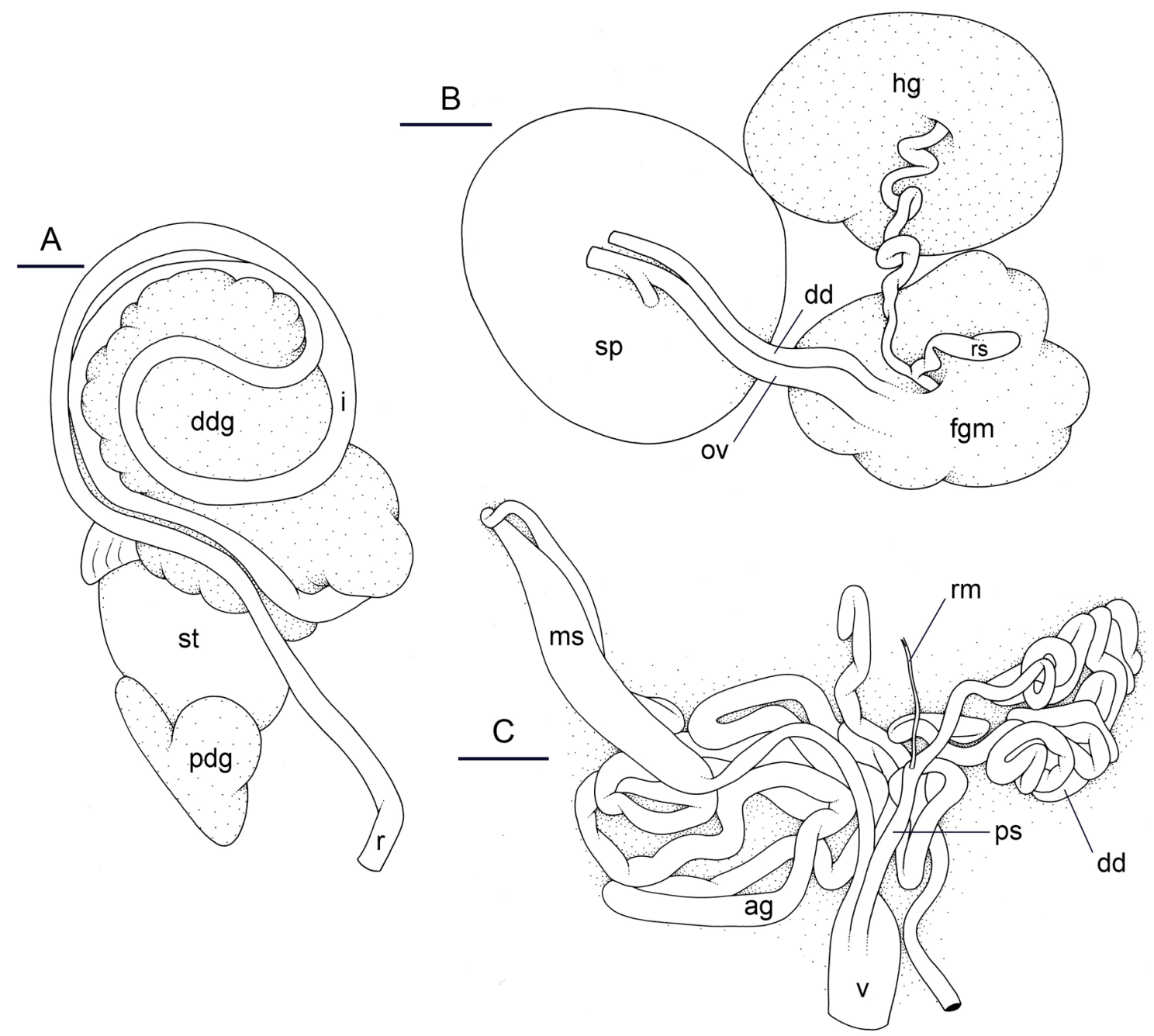

Fig. 33. Paromoionchis boholensis gen. et sp. nov., unit \#1, holotype, Philippines, Bohol [3288] (PNM 041266). A. Digestive system. B. Posterior hermaphroditic (female) reproductive system. C. Male copulatory organs. Abbreviations: ag = accessory penial gland; $\mathrm{dd}=$ deferent duct; $\mathrm{ddg}=$ dorsal lobe of digestive gland; fgm = female gland mass; hd = hermaphroditic duct; hg = hermaphroditic gland; $\mathrm{i}=$ intestine; $\mathrm{ms}=$ muscular sac (of accessory penial gland); ov = oviduct; $\mathrm{pdg}=$ posterior lobe of digestive gland; $p s=$ penial sheath; $r=$ rectum; $r m=$ retractor muscle; $r s=$ receptaculum seminis; $\mathrm{sp}=$ spermatheca; $\mathrm{st}=$ stomach; $\mathrm{v}=$ vestibule. Scales $=2 \mathrm{~mm}$. 
there is a reddish hue on the margin of the dorsal notum (unit \#1). In addition, in most animals the tip of the dorsal papillae (with and without dorsal eyes) can be bright yellow. The foot is orange (unit \#1) or varies from gray to yellow and orange (unit \#2). The hyponotum is also orange, often with a darker ring on the margin which may be bright red (unit \#1) or homogenously gray, yellow, or orange, but can also display a mix of two or three of those colors (unit \#2). The color of both the foot and the hyponotum of an individual can change very rapidly, especially when disturbed. The ocular tentacles are reddish brown and may or may not be speckled with white dots, like the head. The ocular tentacles are short (just a few millimeters long).

Digestive system (Figs 33A, 34A, 35-36)

Radulae measure up to $4.5 \mathrm{~mm}$ (unit \#1) and $4 \mathrm{~mm}$ (unit \#2) in length. Examples of radular formulae are presented in Table 4.
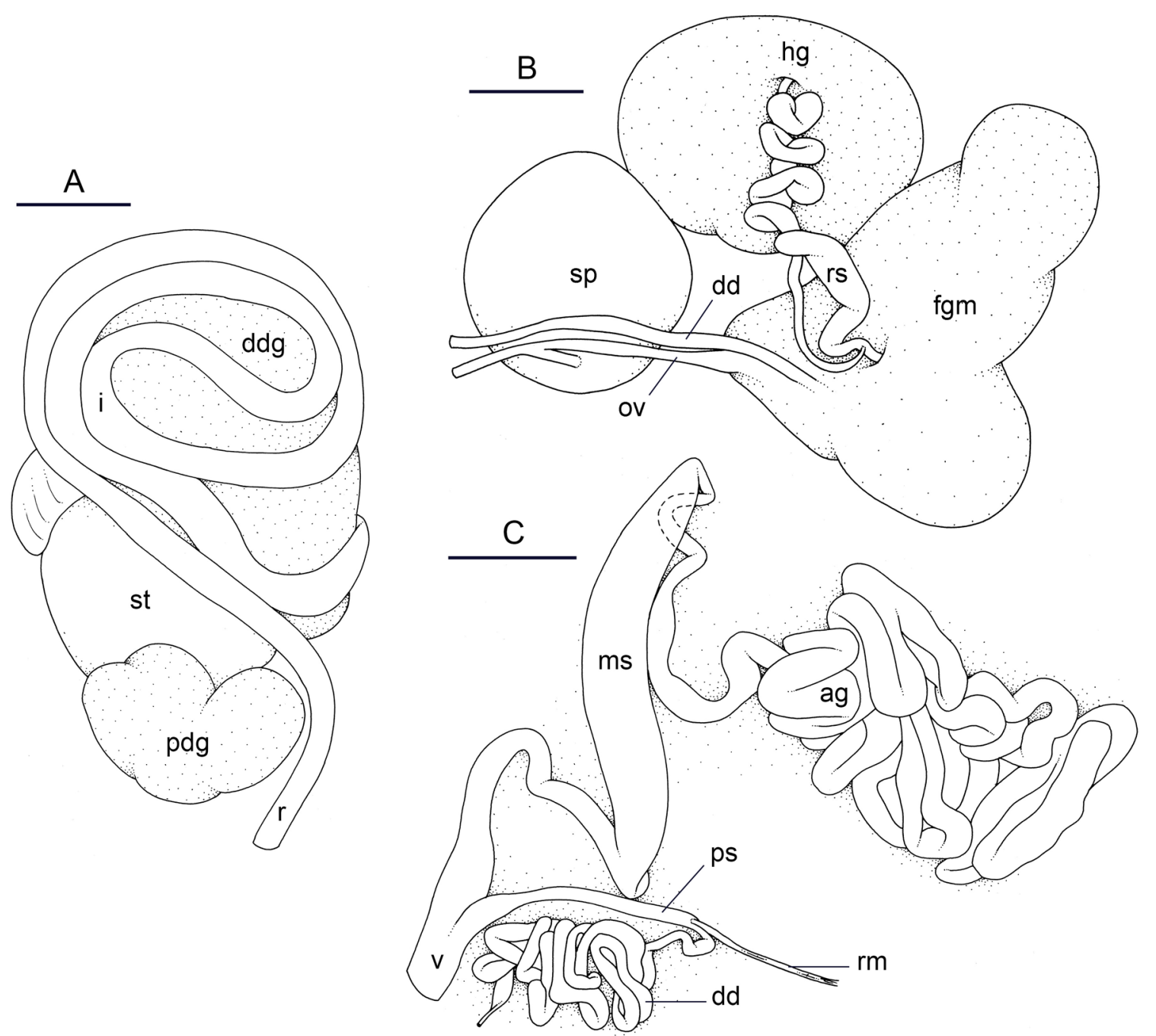

Fig. 34. Paromoionchis boholensis gen. et sp. nov., unit \#2, Indonesia, Bali [3117] (UMIZ 00140). A. Digestive system. B. Posterior hermaphroditic (female) reproductive system. C. Male copulatory organs. Abbreviations: ag = accessory penial gland; $\mathrm{dd}=$ deferent duct; $\mathrm{ddg}=$ dorsal lobe of digestive gland; fgm = female gland mass; hd = hermaphroditic duct; $\mathrm{hg}=$ hermaphroditic gland; $\mathrm{i}=$ intestine; $\mathrm{ms}=$ muscular sac (of accessory penial gland); ov = oviduct; $\mathrm{pdg}=$ posterior lobe of digestive gland; $\mathrm{ps}=$ penial sheath $\mathrm{r}=$ rectum; $\mathrm{rm}=$ retractor muscle; $\mathrm{rs}=$ receptaculum seminis; $\mathrm{sp}=$ spermatheca; $\mathrm{st}=$ stomach; $\mathrm{v}=$ vestibule. Scales: $\mathrm{A}-\mathrm{B}=2 \mathrm{~mm} ; \mathrm{C}=3 \mathrm{~mm}$. 

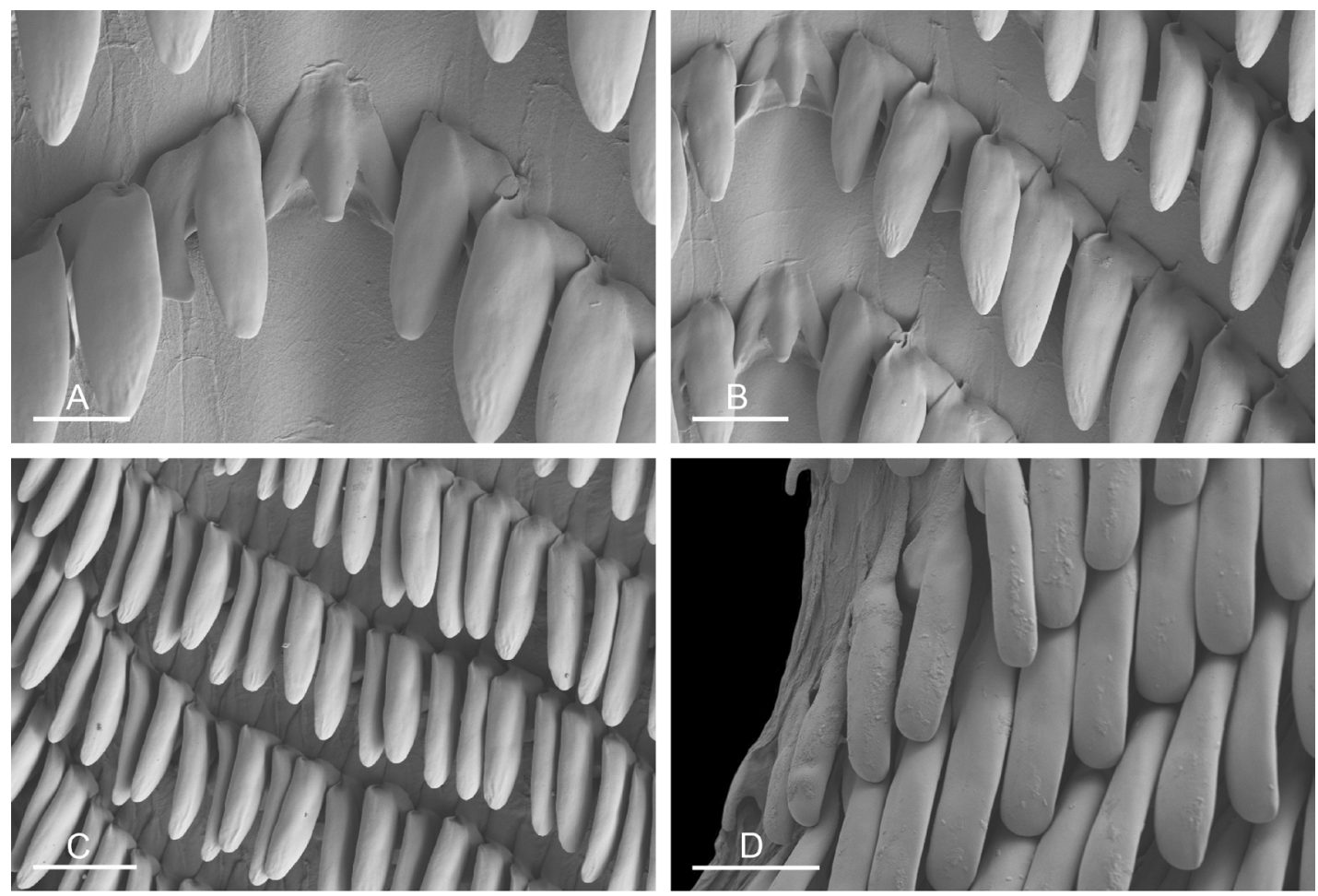

Fig. 35. Paromoionchis boholensis gen. et sp. nov., unit \#1, radula, Philippines, Bohol [3372] (PNM 041269). A. Rachidian and innermost lateral teeth. B. Lateral teeth with rachidian teeth. C. Lateral teeth. D. Outermost lateral teeth. Scales: $\mathrm{A}=20 \mu \mathrm{m} ; \mathrm{B}, \mathrm{D}=30 \mu \mathrm{m} ; \mathrm{C}=50 \mu \mathrm{m}$.
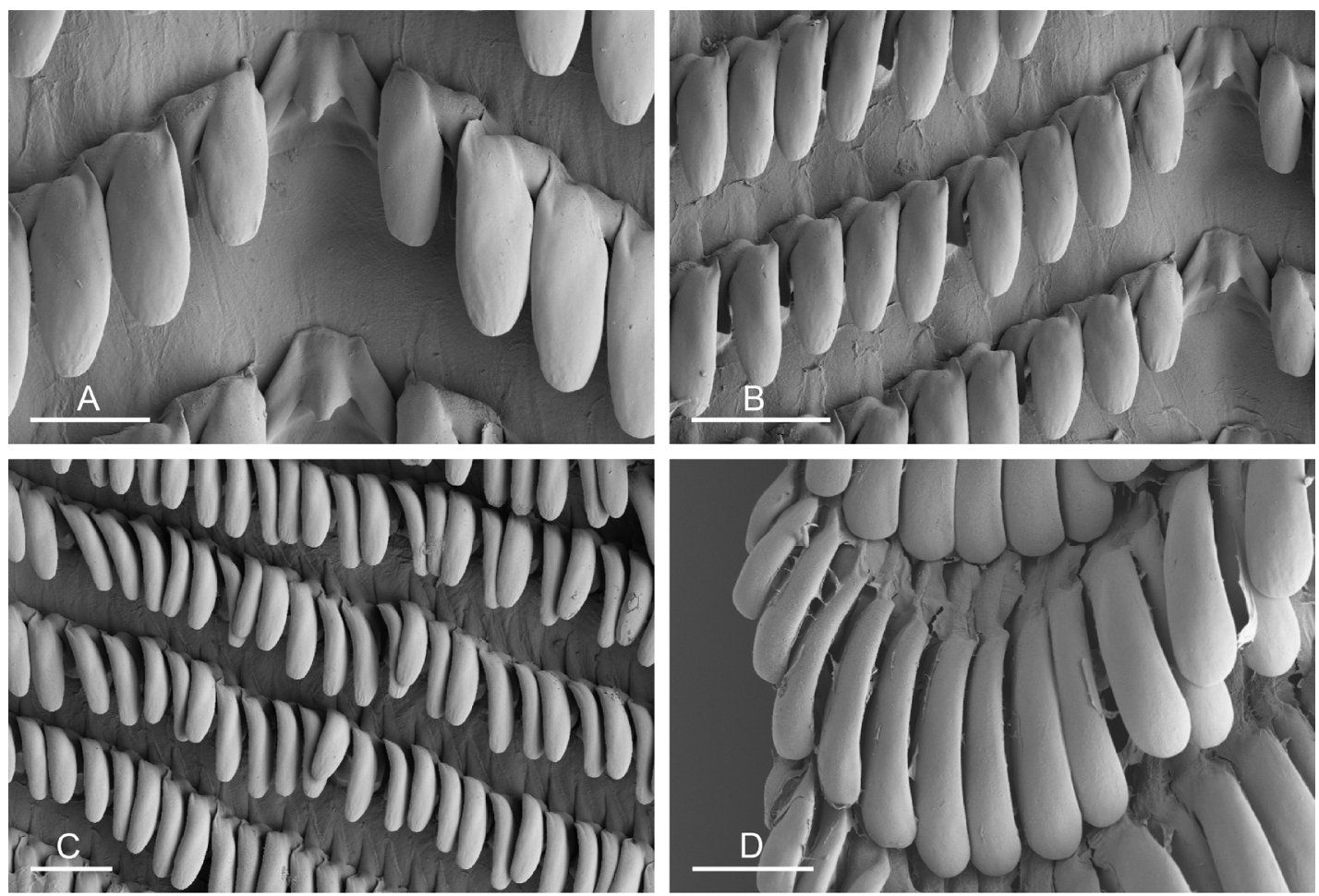

Fig. 36. Paromoionchis boholensis gen. et sp. nov., unit \#2, radula, Indonesia, Ambon [2851] (UMIZ 00146). A. Rachidian and innermost lateral teeth. B. Lateral teeth with rachidian teeth. C. Lateral teeth. D. Outermost lateral teeth. Scales: A, D $=30 \mu \mathrm{m} ; \mathrm{B}-\mathrm{C}=50 \mu \mathrm{m}$. 

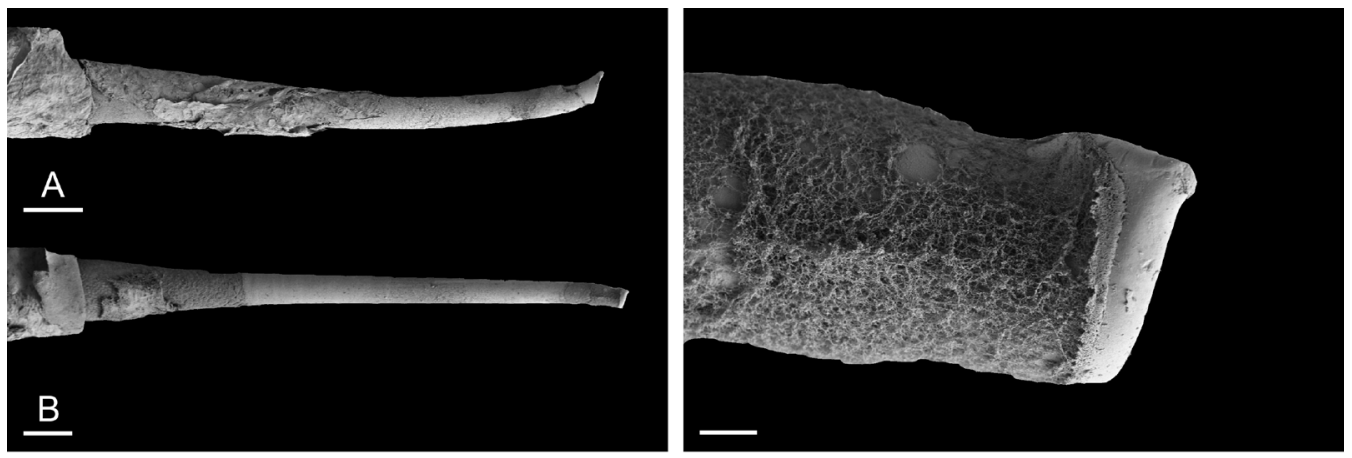

Fig. 37. Paromoionchis boholensis gen. et sp. nov., unit \#1, spine of accessory penial gland. A. Holotype, Philippines, Bohol [3288] (PNM 041266). B. Philippines, Bohol [3372] (PNM 041269). C. Distal tip of spine, same as B. Scales: A-B $=100 \mu \mathrm{m} ; \mathrm{C}=10 \mu \mathrm{m}$.
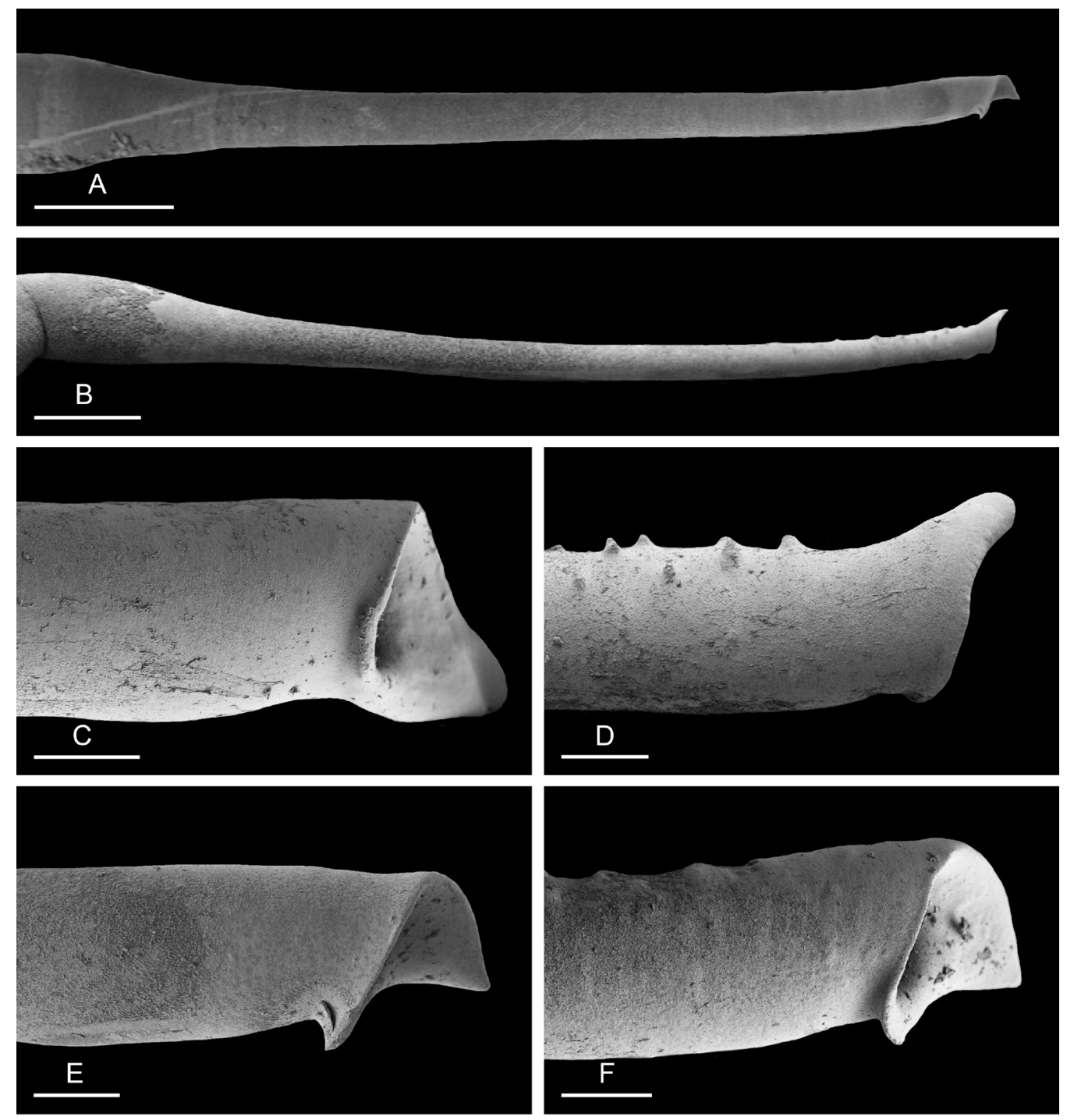

Fig. 38. Paromoionchis boholensis gen. et sp. nov., unit\#2, spine of accessory penial gland. A. Indonesia, Bali [3117] (UMIZ 00140). B. Indonesia, Kei [2911] (UMIZ 00149). C. Tip of spine, Indonesia, Ambon [2851] (UMIZ 00146). D. Distal tip of spine, same as B. E. Tip of spine, same as A. F. Tip of spine, Indonesia, Halmahera [5140] (UMIZ 00152). Scales: A-B $=200 \mu \mathrm{m} ; \mathrm{C}-\mathrm{F}=30 \mu \mathrm{m}$. 


\section{Reproductive system (Figs 33B-C, 34B-C, 37-38)}

The male anterior organs consist of the penial complex (penis, penial sheath, vestibule, deferent duct, retractor muscle) and the accessory penial gland (flagellum and hollow spine). The hollow spine of the accessory penial gland is narrow, elongated, slightly curved. Its base is conical. Its diameter is approximately 50 to $70 \mu \mathrm{m}$ for most of its length and 100-130 $\mu \mathrm{m}$ at its base (unit \#1) and approximately 70 to $80 \mu \mathrm{m}$ for most of its length and 150-200 $\mu \mathrm{m}$ at its base (unit \#2). Its length ranges from $1 \mathrm{~mm}$ ([3288] PNM 041266, holotype) to $1.2 \mathrm{~mm}$ ([3372] PNM 041269) in unit \#1 and from $1.1 \mathrm{~mm}$ ([5019] UMIZ 00151) and $1.3 \mathrm{~mm}$ ([3117] UMIZ 00140) to $1.8 \mathrm{~mm}$ ([2911] UMIZ 00149, [5140] UMIZ 00152) in unit \#2, and its shape does vary between individuals (Fig. 38). The penial sheath is narrow and elongated. The retractor muscle is vestigial, i.e., with its distal end being free in the visceral cavity, with no clear insertion (unit \#1), or absent or vestigial (unit \#2). The deferent duct is highly convoluted, with many loops. Inside the penial sheath, the penis is a narrow, elongated, soft, smooth (no hooks) and hollow tube of approximately $200 \mu \mathrm{m}$ in diameter.

\section{Distinctive diagnostic features}

Externally, the color of the foot and hyponotum can help one to identify Paromoionchis boholensis gen. et sp. nov., but unfortunately it is not fully reliable. Specimens with a bright orange foot and hyponotum are only found in P. boholensis gen. et sp. nov., especially in unit \#1 but also in unit \#2; the
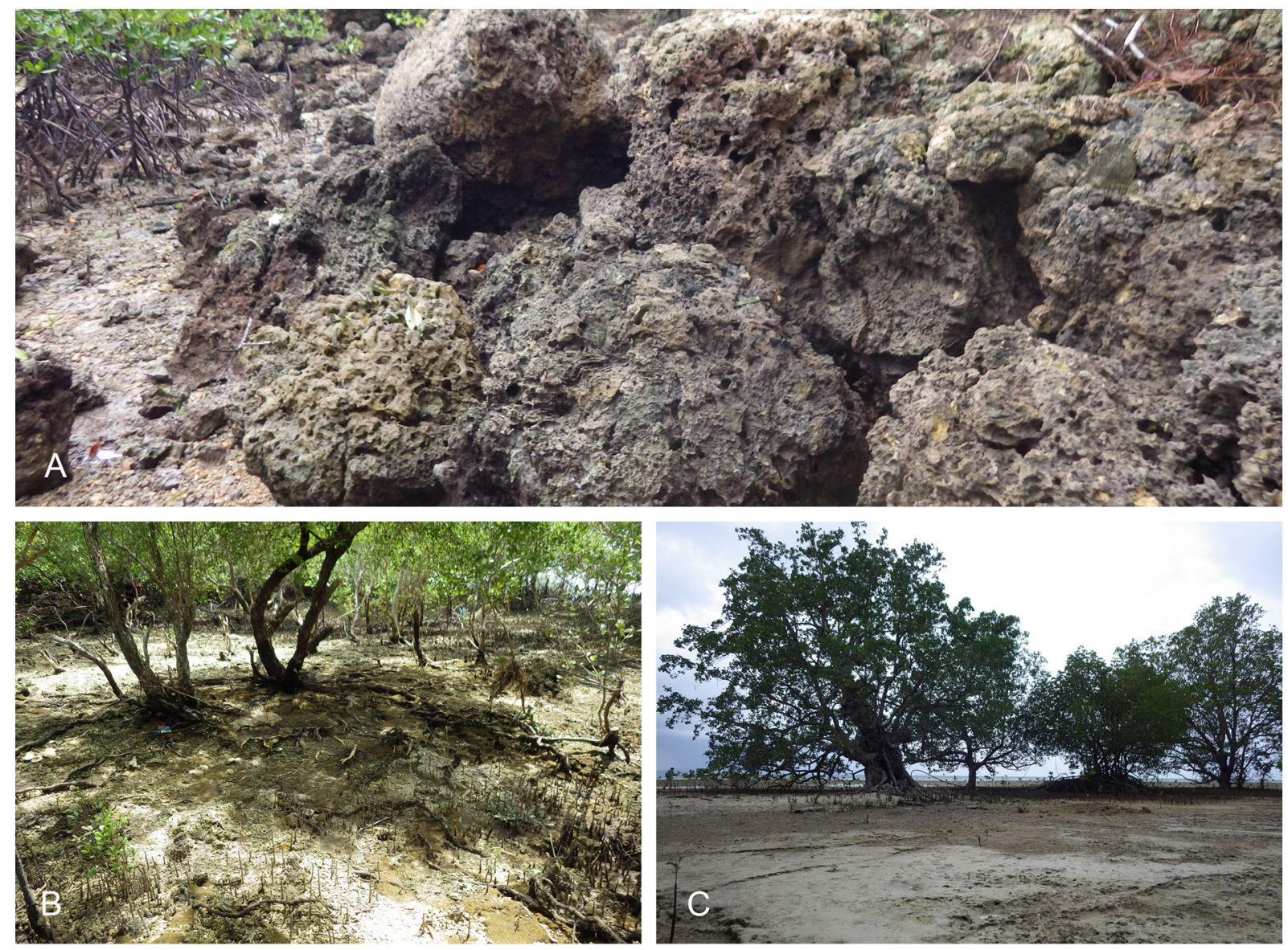

Fig. 39. Paromoionchis boholensis gen. et sp. nov., unit \#1, habitats. A. Philippines, Bohol, Maribojoc, large porous rocks behind mangrove (station 193, type locality). B. Philippines, Bohol, Mabini, open Avicennia and Sonneratia forest with large gravel of coral pieces, sand and algae on surface (station 196). C. Philippines, Bohol, Maribojoc, uplifted, dead coral flat covered with sand and algae adjacent to a few mangrove trees (station 202). 

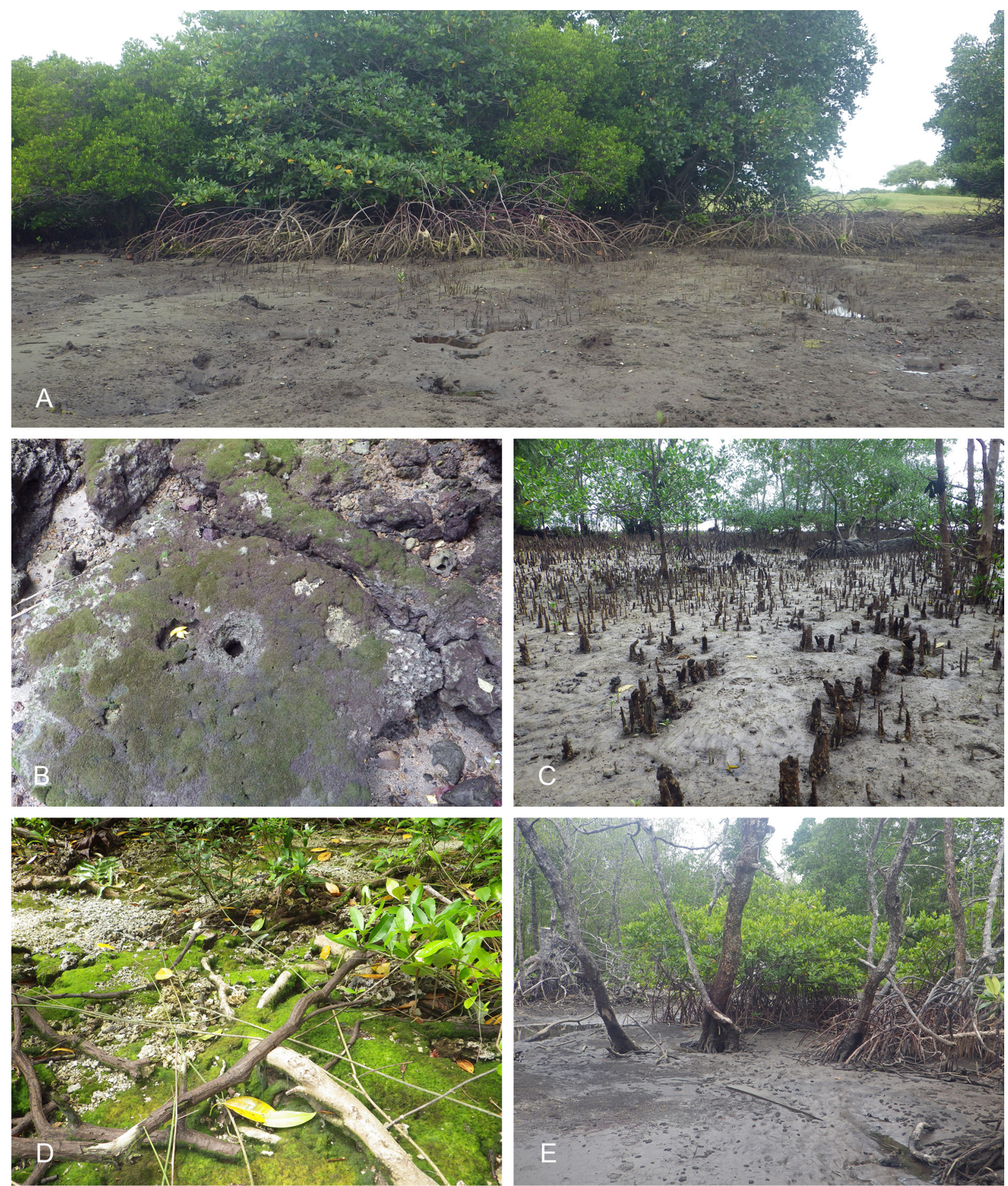

Fig. 40. Paromoionchis boholensis gen. et sp. nov., unit \#2, habitats. A. Indonesia, Bali, muddy mangrove with Rhizophora and Avicennia trees (station 156). B. Indonesia, Sulawesi, sand, small rocks and pieces of wood outside a narrow coastal mangrove (station 88). C. Indonesia, Ambon, narrow band of old Avicennia trees on sandy mud, with old logs on ground (station 132). D. Indonesia, Kei, back of mangrove with rocks, mud, logs and leaf litter (station 140). E. Indonesia, Halmahera, mostly Rhizophora, with some sandy areas and some open muddy areas (station 219). 
ventral side of $P$. tumidus, which is sympatric with P. boholensis (Fig. 6), can be orange but not bright orange. However, specimens with a more yellowish or greyish foot and hyponotum cannot be identified externally. The internal anatomy of $P$. boholensis gen. et sp. nov. (accessory penial gland, vestigial penial retractor muscle, penis with no hooks) is similar to that of $P$. daemelii. However, $P$. boholensis gen. et sp. nov. and $P$. daemelii do not overlap geographically, at least based on the present data. Thus, within its distribution range $P$. boholensis gen. et sp. nov. is the only species with this combination of internal characters. Indeed, the internal characters of the two species of Paromoionchis gen. nov. with which $P$. boholensis gen. et sp. nov. is sympatric ( $P$. goslineri gen. et sp. nov. and $P$. tumidus) are different (Table 3). It must be noted that the known distribution of species of Paromoionchis gen. nov. may change as new records are found in the future and so the use of geographic data should only be used with caution for identification.

\section{Distribution (Fig. 6)}

Philippines (unit \#1): Bohol (type locality), Luzon. Indonesia (unit \#2): Ambon, Bali, Halmahera, Kei Islands, Seram, Sulawesi.

\section{Habitat (Figs 39-40)}

Unit \#1 of Paromoionchis boholensis gen. et sp. nov. is found on sandy mud or sand with very little mud, in mangroves or near mangrove trees and is rare (it was found at only four stations). Unit \#2 is found in open or dense mangroves, on soft or hard mud, as well as on muddy sand and is common (but not as common as $P$. tumidus unit \#1).

Paromoionchis penangensis Dayrat \& Goulding gen. et sp. nov. urn:1sid:zoobank.org:act:840ABD3E-61AC-4B1E-9D83-B15A8099F0BA

Figs $41-44$

\section{Etymology}

Paromoionchis penangensis gen. et sp. nov. is named after Penang Island, Malaysia, in the Strait of Malacca, which is the type locality.

\section{Material examined}

\section{Holotype}

MALAYSIA • holotype (26/14 [6037] mm); Peninsular Malaysia, Penang, Pantai Acheh; 05²4.922' N, $100^{\circ} 11.571^{\prime}$ E; 1 Aug. 2016; station 261; Avicennia mangrove, with both very soft mud and hard mud; USMMC 00059.

\section{Other material}

INDIA -Andaman Islands • 1 spec. (18/10 [1086] mm); Middle Andaman, Rangat, Yerrata, Saban; $12^{\circ} 27.451^{\prime} \mathrm{N}, 092^{\circ} 53.792^{\prime} \mathrm{E}$; 10 Jan. 2011; station 56; open, impacted mangrove patch by a creek, near village, with medium trees and old logs; BNHS $92 \cdot 2$ spec. (18/8 [1100] and 9/6 [1101] mm); Middle Andaman, Rangat, Shyamkund; $12^{\circ} 28.953^{\prime}$ N, 092 $50.638^{\prime}$ E; 11 Jan. 2011; station 57; by a large river, deep mangrove with tall trees, small creeks and plenty of old logs, next to a road and a small cemented bridge over a creek; BNHS 53 2 spec. (20/10 [1117] and 22/12 [1118] mm); Middle Andaman, Shantipur, Kadamtala; $12^{\circ} 19.843^{\prime}$ N, $092^{\circ} 46.377^{\prime}$ E; 12 Jan. 2011; station 58; open area with hard mud and many old logs, next to a mangrove with medium trees; BNHS $11 \cdot 2$ spec. (30/15 [1129]

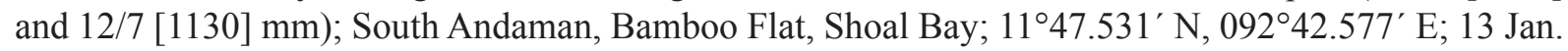
2011; station 59; open mangrove with medium trees, hard mud, dead logs, next to a road and a small cemented bridge for creek; BNHS 4. - Maharashtra 1 spec. $\left(35 / 20\right.$ [1167] mm); Watad; $17^{\circ} 15.791^{\prime} \mathrm{N}$, $73^{\circ} 17.623^{\prime}$ E; 23 Dec. 2011; station 46; Avicennia mangrove, by field, with deep and very watery mud; BNHS $46 \cdot 3$ spec. (30/18 [1177], 20/14 [1175] and 15/10 [1173] mm); same data as for preceding; 

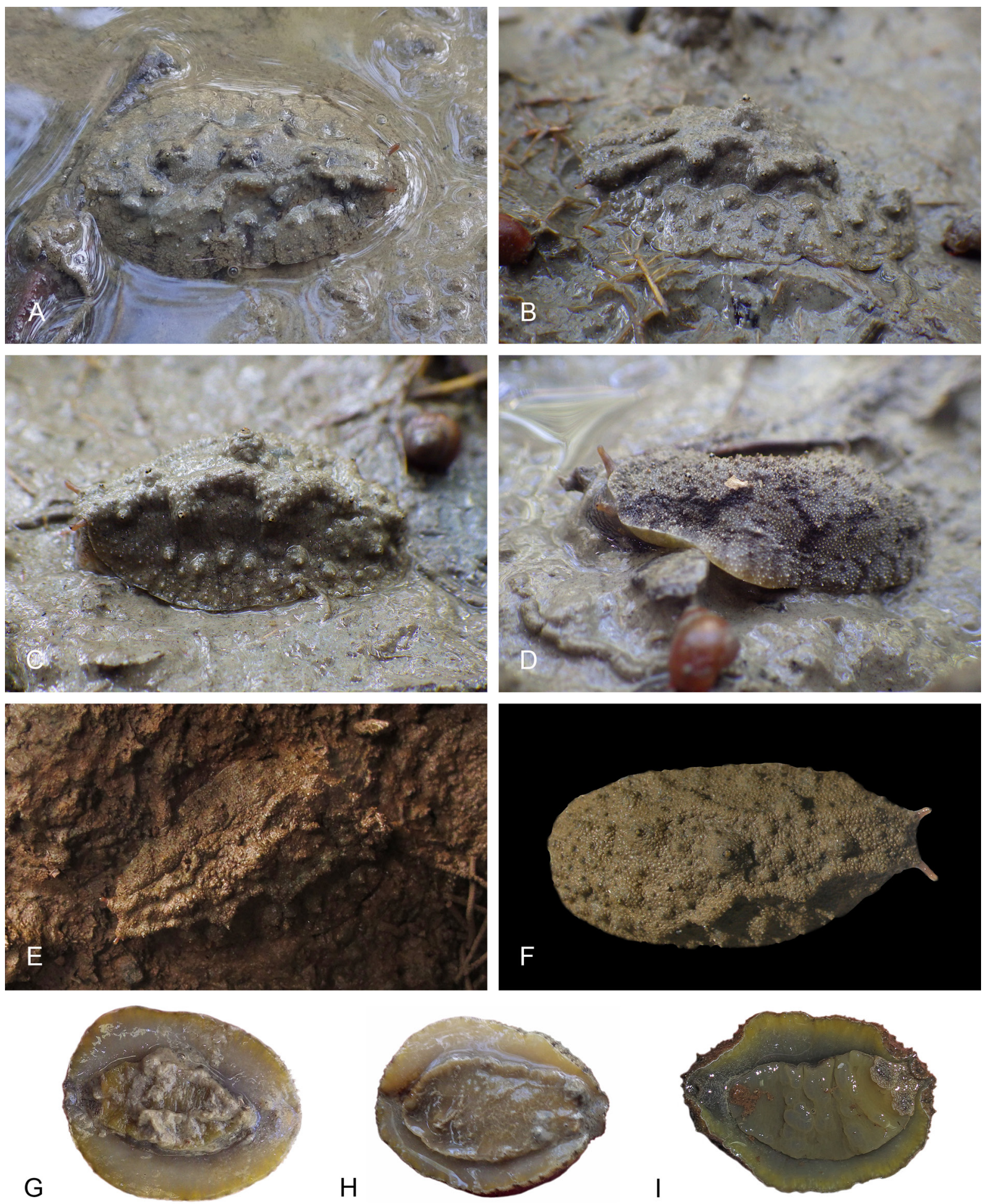

Fig. 41. Paromoionchis penangensis gen. et sp. nov., live animals. A. Dorsal view, $29 \mathrm{~mm}$ long [5990], Malaysia, Matang (USMMC 00060). B. Dorsal view, 26 mm long [6039], Malaysia, Penang (USMMC 00063). C. Holotype, dorsal view, $25 \mathrm{~mm}$ long [6037], Malaysia, Penang (USMMC 00059). D. Dorsal view, $22 \mathrm{~mm}$ long [6031], Malaysia, Penang (USMMC 00063). E. Dorsal view, $37 \mathrm{~mm}$ long [1167], India, Maharashtra (BNHS 46). F. Dorsal view, $30 \mathrm{~mm}$ long [1129], India, Andaman Islands (BNHS 4). G. Ventral view, same as D. H. Ventral view, same as A. I. Ventral view, $27 \mathrm{~mm}$ long [1182], India, Maharashtra (BNHS 42). 
BNHS $98 \cdot 2$ spec. (16/11 [1176] and 27/21 [1182] mm); Aare Ware; $17^{\circ} 04.404^{\prime} \mathrm{N}, 73^{\circ} 17.747^{\prime} \mathrm{E}$; 24 Dec. 2011; station 47; mangrove with soft mud and some areas with pools, mostly Avicennia with a few small Rhizophora; BNHS 42.

MALAYSIA - Peninsular Malaysia - 2 spec. (30/20 [5990] and 30/20 [5991] mm); Kuala Gula; 04 $55.991^{\prime} \mathrm{N}, 100^{\circ} 26.917^{\prime}$ E; 29 Jul. 2016; station 259; mostly Avicennia, a few Bruguiera and Rhizophora, along a creek, both soft and hard mud; USMMC 00060 2 spec. (20/14 [957] and 15/10 [958] mm); Nibong Tebal, Pulau Burung; 05¹2.488’ N, 100²5.564' E; 11 Jul. 2011; station 17; soft mud, open mangrove of Rhizophora, with a few Sonneratia; USMMC $00061 \bullet 1$ spec. (48/35 [6020] $\mathrm{mm}$ ); Nibong Tebal, Pulau Burung; $05^{\circ} 12.488^{\prime} \mathrm{N}, 100^{\circ} 25.564^{\prime} \mathrm{E}$; 30 Jul. 2016; station 260; soft mud, open mangrove of Rhizophora, with a few Sonneratia; USMMC 00062 • 3 spec. (25/12 [6031], 25/18 [6033] and 25/16 [6039] mm); same data as for holotype; USMMC 00063.

\section{Color and morphology of live animals (Fig. 41)}

Live animals are most often covered with mud, in which case their dorsal color can hardly be seen. The background of the dorsal notum is brown, occasionally mottled with darker or lighter areas. In addition,
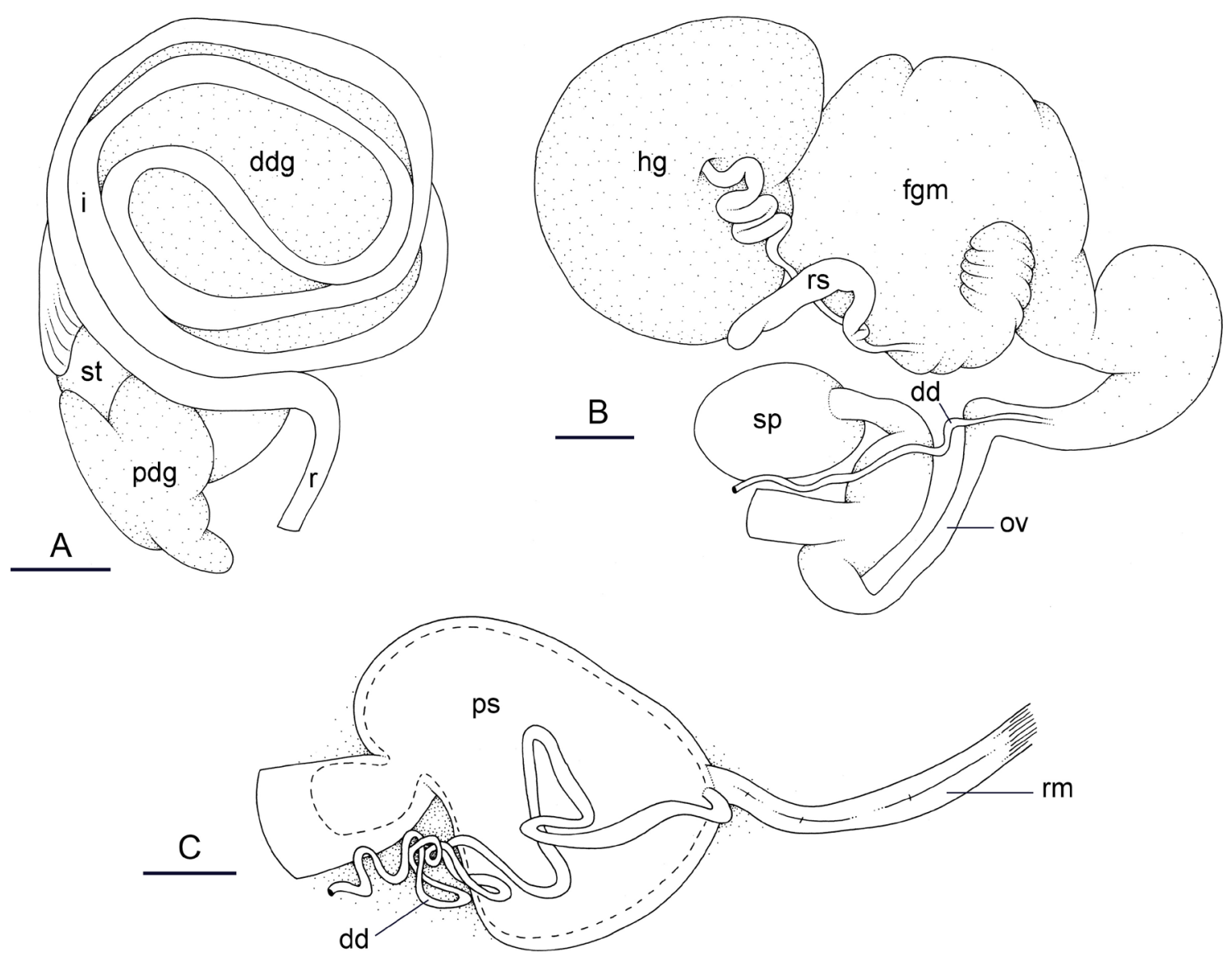

Fig. 42. Paromoionchis penangensis gen. et sp. nov., holotype, Malaysia, Penang [6037] (USMMC 00059). A. Digestive system. B. Posterior hermaphroditic (female) reproductive system. C. Male copulatory organs. Abbreviations: $\mathrm{dd}=$ deferent duct; $\mathrm{ddg}=$ dorsal lobe of digestive gland; fgm = female gland mass; hd = hermaphroditic duct; hg = hermaphroditic gland; $\mathrm{i}=$ intestine; ov = oviduct; $\mathrm{pdg}=$ posterior lobe of digestive gland; $\mathrm{ps}=$ penial sheath (penis inside indicated by dotted line); $\mathrm{r}=$ rectum; $\mathrm{rm}=$ retractor muscle; $\mathrm{rs}=$ receptaculum seminis; $\mathrm{sp}=$ spermatheca; $\mathrm{st}=$ stomach. Scales: $\mathrm{A}=2 \mathrm{~mm} ; \mathrm{B}-\mathrm{C}=1 \mathrm{~mm}$. 
in some animals, the tip of dorsal papillae (with and without dorsal eyes) can be yellow. The foot is gray, occasionally with a light yellow hue. The hyponotum is uniform gray or gray (inner ring) and yellow (outer ring). The color of both the foot and the hyponotum of an individual can change rapidly, especially when disturbed. The ocular tentacles are brown and may or may not be speckled with white dots, like the head. The ocular tentacles are short (just a few mm long).

Digestive system (Figs 42A, 43)

Radulae measure up to $3.2 \mathrm{~mm}$ in length. Examples of radular formulae are presented in Table 4.
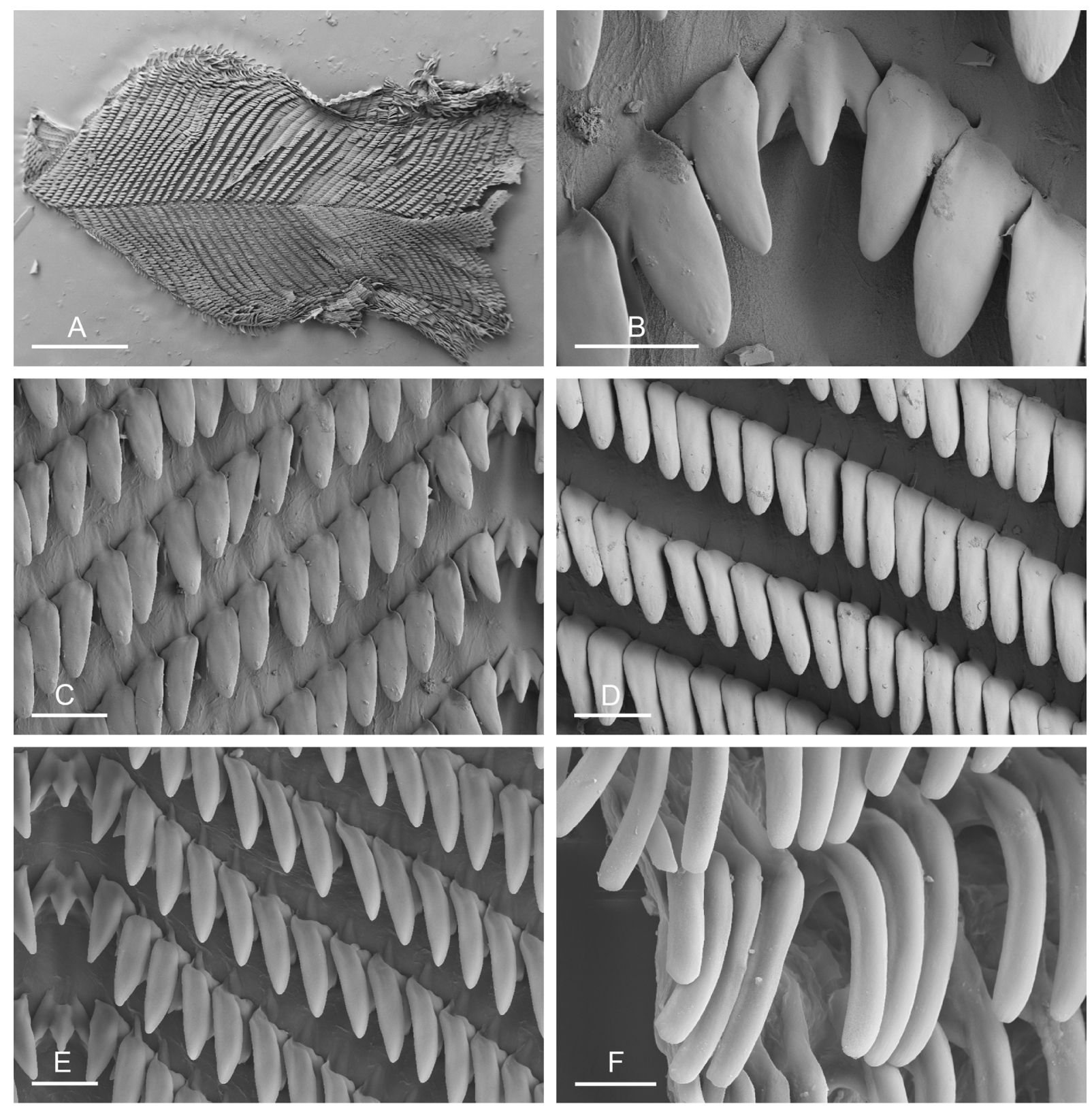

Fig. 43. Paromoionchis penangensis gen. et sp. nov., radula. A-D. Holotype, Malaysia, Penang [6037] (USMMC 00059). A. Entire radula. B. Rachidian and innermost lateral teeth. C. Lateral teeth with rachidian teeth. D. Lateral teeth. E-F. Western Peninsular Malaysia [6020] (USMMC 00062). E. Lateral teeth with rachidian teeth. F. Outermost lateral teeth. Scales: A $=0.5 \mathrm{~mm} ; \mathrm{B}, \mathrm{F}=20 \mu \mathrm{m} ; \mathrm{C}-\mathrm{E}=30 \mu \mathrm{m}$. 


\section{Reproductive system (Fig. 42B-C)}

In the posterior (female) organs, the distal portion of the oviduct and of the duct to the spermatheca is wider than in other species, which makes sense given the wide penis. The male anterior organs consist of the penial complex (penis, penial sheath, vestibule, deferent duct, retractor muscle). An accessory penial gland is absent. The penial sheath is large (at least ten times as large as the deferent duct). The retractor muscle is strong, long and inserts near the heart. The deferent duct is convoluted, with many loops. Inside the penial sheath, the penis is a large (wider than long), smooth (no hooks), muscular mass.

\section{Distinctive diagnostic features}

Externally, Paromoionchis penangensis gen. et sp. nov. cannot be reliably distinguished from other species of Paromoionchis gen. nov. Its distribution only overlaps with that of P. tumidus. Our data suggest that the tips of the dorsal papillae of $P$. penangensis gen. et sp. nov. tend to be paler yellow, while they tend to be brighter yellow in $P$. tumidus. However, the internal anatomy of $P$. penangensis gen. et sp. nov., especially the large penis inside the large penial sheath, is very distinct from that of all other species and reliably distinguishes it from P. tumidus.
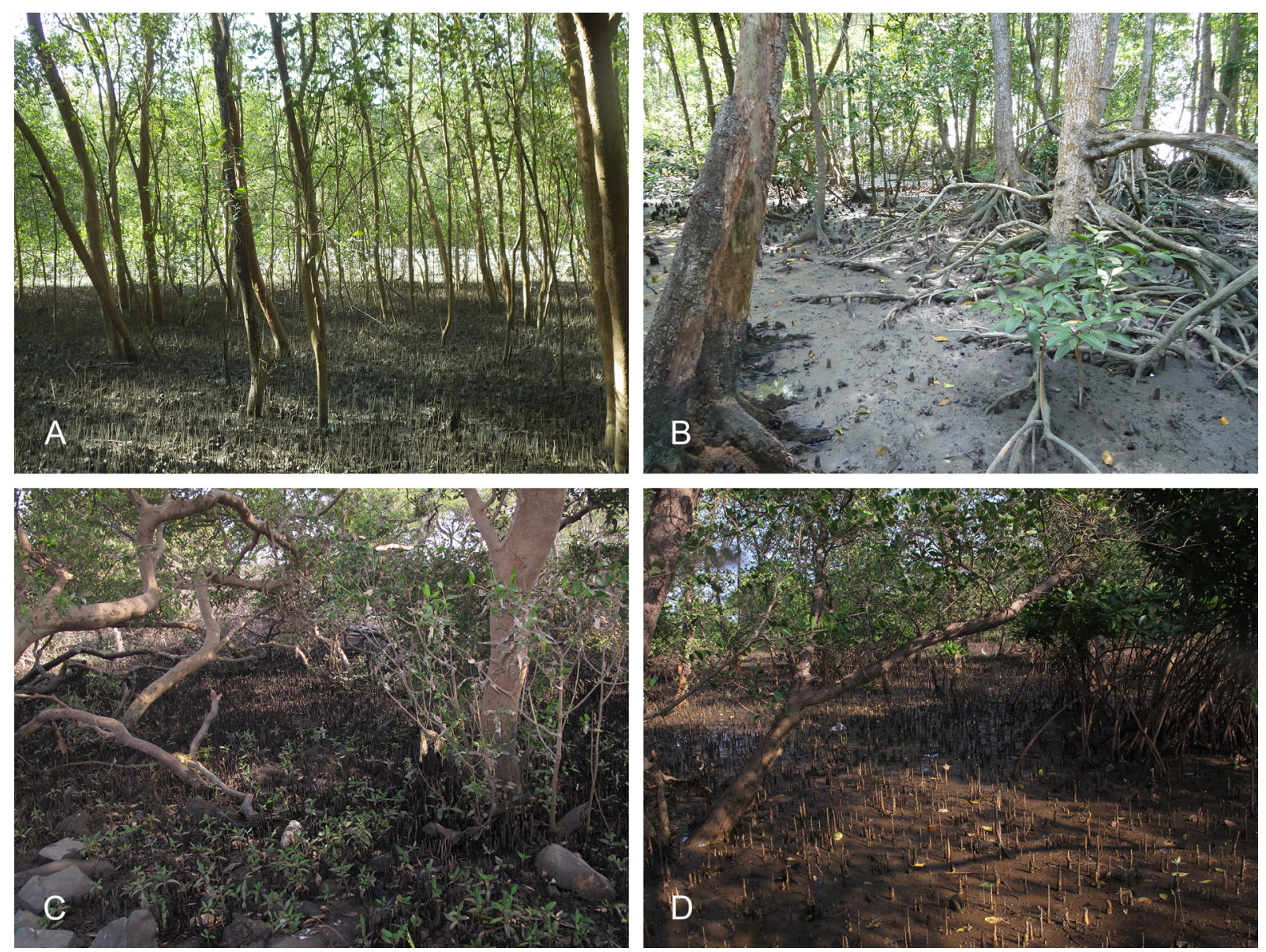

Fig. 44. Paromoionchis penangensis gen. et sp. nov., habitats. A. Malaysia, Penang, open Avicennia mangrove with different types of mud (station 261, type locality). B. Western Peninsular Malaysia, Rhizophora and Sonneratia mangrove with soft mud, next to a landfill (station 17). C. India, Maharashtra, Avicennia mangrove with soft mud and a wall of large rocks (station 45). D. India, Maharashtra, Avicennia mangrove with a few small Rhizophora, soft mud and pools (station 47). 


\section{Distribution (Fig. 6)}

Malaysia: Peninsular Malaysia, Strait of Malacca (type locality). India: Andaman Islands (Bay of Bengal), Maharashtra (W coast of India).

\section{Habitat (Fig. 44)}

Paromoionchis penangensis gen. et sp. nov. is found on soft and hard mud, in mangroves or in open areas near mangroves. This species was only found at three stations in the Strait of Malacca, three stations in the Andaman Islands (Bay of Bengal), and three stations in Maharashtra (W coast of India). However, at each station it was found to be quite abundant.

Paromoionchis goslineri Dayrat \& Goulding gen. et sp. nov. urn:lsid:zoobank.org:act:E375A628-4AE6-4E10-B424-D4BBF58F8941

Figs 45-51

\section{Etymology}

Paromoionchis goslineri gen. et sp. nov. is dedicated to Dr. Terry Gosliner, Senior Curator at the California Academy of Sciences, San Francisco, California, USA, who has been exploring the marine life of the Batangas region for many years, where this new species was found, and, more importantly, for years ago providing the first author with a great post-doctoral opportunity to focus on alpha-taxonomy.

\section{Material examined}

Holotype

PHILIPPINES - holotype (25/15 [3233] mm); Luzon, Calantagan, Batangas; 1351.264' N, $120^{\circ} 37.383^{\prime} \mathrm{E}$; 8 Jul. 2014; station 185; next to village, impacted narrow mangrove forest of Avicennia by the shore; PNM 041271.

\section{Other material}

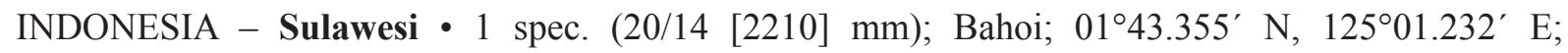
12 Mar. 2013; station 88; sand, small rocks and pieces of wood outside narrow coastal

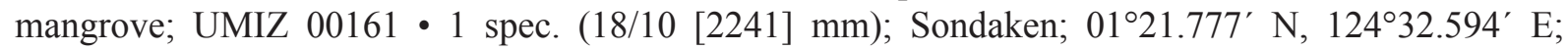
13 Mar. 2013; station 89; mostly Rhizophora, with sand, small rocks and pieces of wood outside narrow coastal mangrove; UMIZ 00153. - Bali • 3 spec. (22/15 [3060], 22/15 [3066] and 27/20 [3068] $\mathrm{mm}$ ); Denpasar; $08^{\circ} 46.126^{\prime} \mathrm{S}, 115^{\circ} 10.803^{\prime} \mathrm{E}$; 2 Apr. 2014; station 154; large mangrove by road, with shallow mud; UMIZ 00154 • 4 spec. (20/12 [3072], 17/10 [3074], 22/14 [3078] and 24/14 [3079] mm); Gilimanuk; $08^{\circ} 10.259^{\prime} \mathrm{S}, 114^{\circ} 26.606^{\prime} \mathrm{E}$; 3 Apr. 2014 ; station 155 ; from high intertidal with water pools and many mounds up to shore with sand and rocks; UMIZ 00155 - 2 spec. (22/10 [3118] and 37/20 [3120] mm); Gilimanuk; $08^{\circ} 10.156^{\prime} \mathrm{S}, 114^{\circ} 26.652^{\prime} \mathrm{E}$; 4 Apr. 2014; station 156 ; muddy mangrove with Rhizophora and Avicennia trees; UMIZ 00156. - Timor • 2 spec. (12/7 [5890] and 15/7 [5891] mm); Oesapa; $10^{\circ} 08.732^{\prime} \mathrm{S}, 123^{\circ} 38.096^{\prime}$ E; 11 Jul. 2016; station 250; sandy part of mangrove, with Sonneratia and Avicennia; UMIZ 00157. - Halmahera - 2 spec. (24/16 [5072] and 32/23 [5073] mm); Dodinga; $00^{\circ} 51.348^{\prime} \mathrm{N}, 127^{\circ} 38.504^{\prime} \mathrm{E}$; 9 Mar. 2015; station 206; back of mangrove, high intertidal, with ferns and

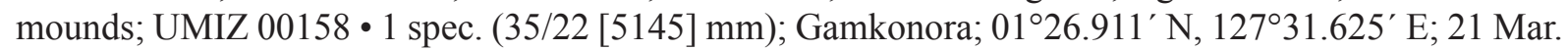
2015; station 219; mostly Rhizophora, with some sandy and open muddy areas; UMIZ 00159. - Ambon •

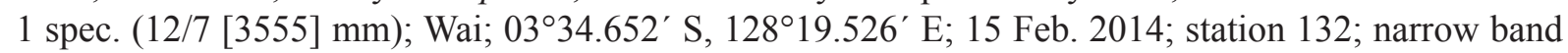
of old Avicennia trees on sandy mud, with old logs; UMIZ 00160.

PHILIPPINES - Luzon - 2 spec. (22/15 [3221] and 20/16 [6049] mm); Calantagan, Batangas; $13^{\circ} 53.278^{\prime} \mathrm{N}, 120^{\circ} 37.124^{\prime} \mathrm{E}$; 8 Jul. 2014; station 184; narrow forest on the shore, with Avicennia and young Rhizophora; PNM $041272 \cdot 1$ spec. $(28 / 20$ [3232] mm); same data as for holotype; PNM 041273. 


\section{Color and morphology of live animals (Figs 45-46)}

Live animals are most often covered with mud, in which case their dorsal color can hardly be seen. The background of the dorsal notum is gray-brown, mottled with darker and lighter areas. In addition, in some animals, the tip of dorsal papillae (with and without dorsal eyes) can be lighter (pale yellow or white). The foot and the hyponotum are dark or light gray. The color of both the foot and the hyponotum of an individual can change rapidly, especially when disturbed. The ocular tentacles are gray-brown and may or may not be speckled with white dots, like the head. The ocular tentacles are short (just a few millimeters long). The tip of dorsal papillae is usually white or pale yellow, but not always (in any case generally covered with mud).

\section{Digestive system (Figs 47A, 48A, 49-50)}

Radulae measure up to $2.6 \mathrm{~mm}$ (unit \#1) and $2.2 \mathrm{~mm}$ (unit \#2) in length. Examples of radular formulae are presented in Table 4.

\section{Reproductive system (Figs 47B-C, 48B-C)}

The male anterior organs consist of the penial complex (penis, penial sheath, vestibule, deferent duct, retractor muscle). An accessory penial gland is absent. The penial sheath is narrow and elongated. In unit \#1, the retractor muscle is very short (much shorter than the penial sheath), inserting on the body
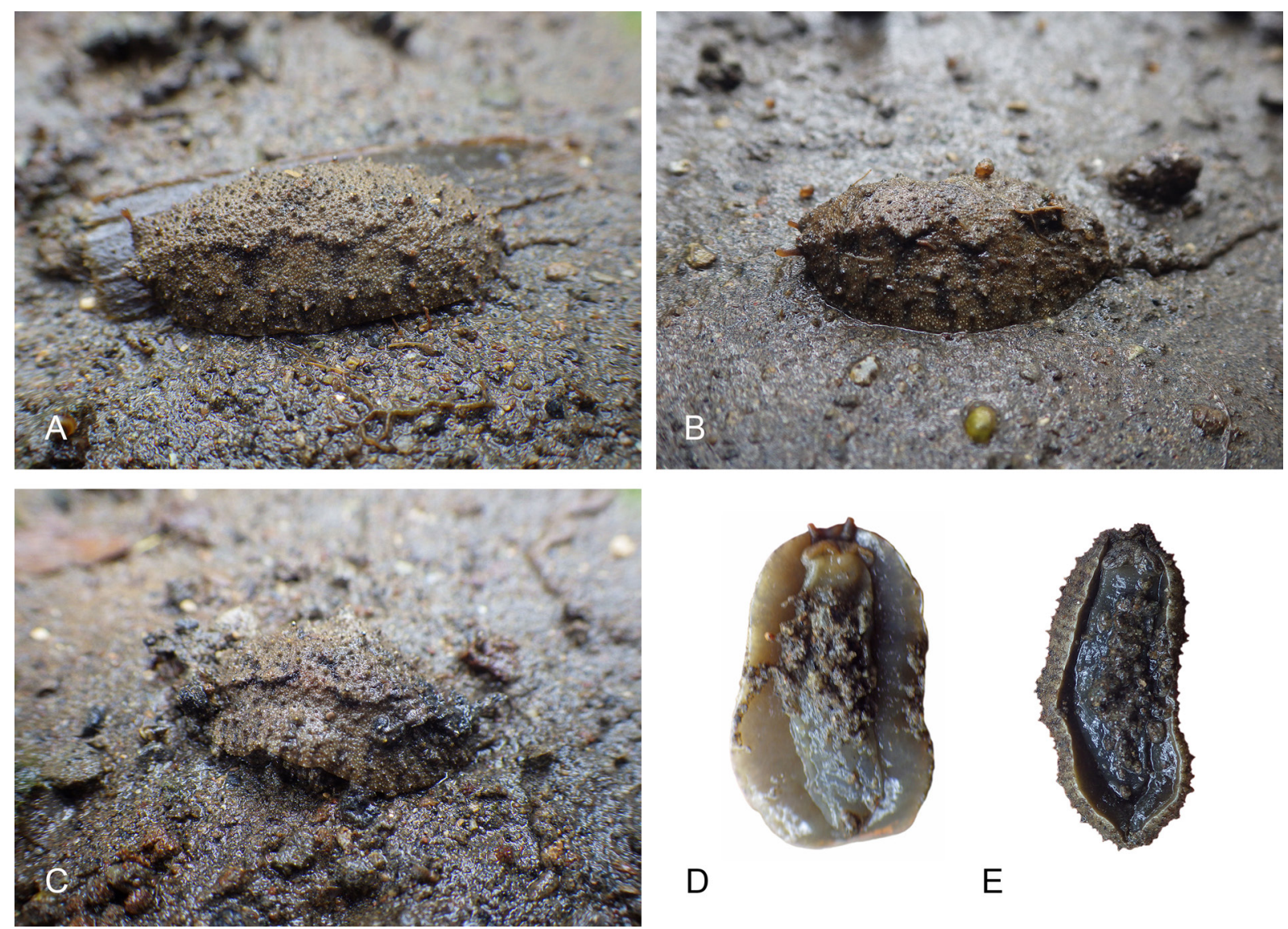

D

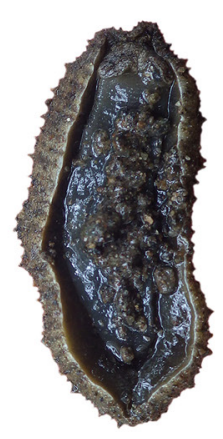

$E$

Fig. 45. Paromoionchis goslineri gen. et sp. nov. unit \#1, live animals, Philippines, Luzon. A. Dorsal view, $30 \mathrm{~mm}$ long [3232] (PNM 041273). B. Dorsal view, $22 \mathrm{~mm}$ long [3221] (PNM 041272). C. Holotype, dorsal view, $25 \mathrm{~mm}$ long [3233] (PNM 041271). D. Ventral view, same as B. E. Ventral view, same as A. 
wall near the nervous system, or vestigial (its distal end being free in the visceral cavity, with no clear insertion). In unit \#2, the retractor muscle is long (as long as the penial sheath), inserting near the heart. The deferent duct is also highly convoluted, with many loops. Inside the penial sheath, the penis is a narrow, elongated, soft, smooth (no hooks) and hollow tube of approximately $200 \mu \mathrm{m}$ in diameter.

\section{Distinctive diagnostic features}

Externally, Paromoionchis goslineri gen. et sp. nov. cannot be distinguished from other species of Paromoionchis gen. nov. The ventral side (foot and hyponotum) is gray, i.e., never yellow or orange. Unfortunately, a gray ventral side can occasionally be found in all other species of the genus, so the use of that color trait is not fully reliable for identification. However, the internal anatomy of $P$. goslineri
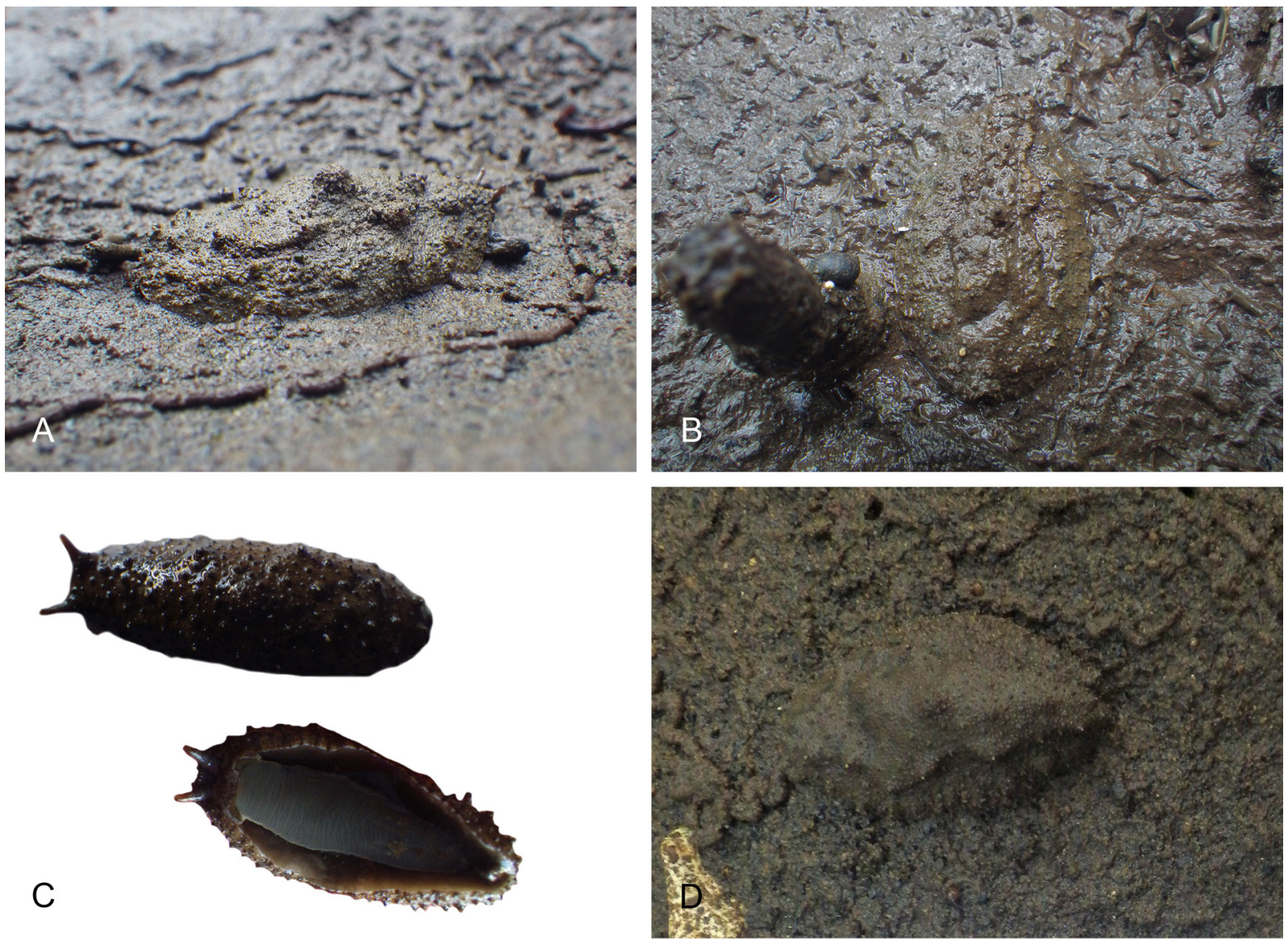

C
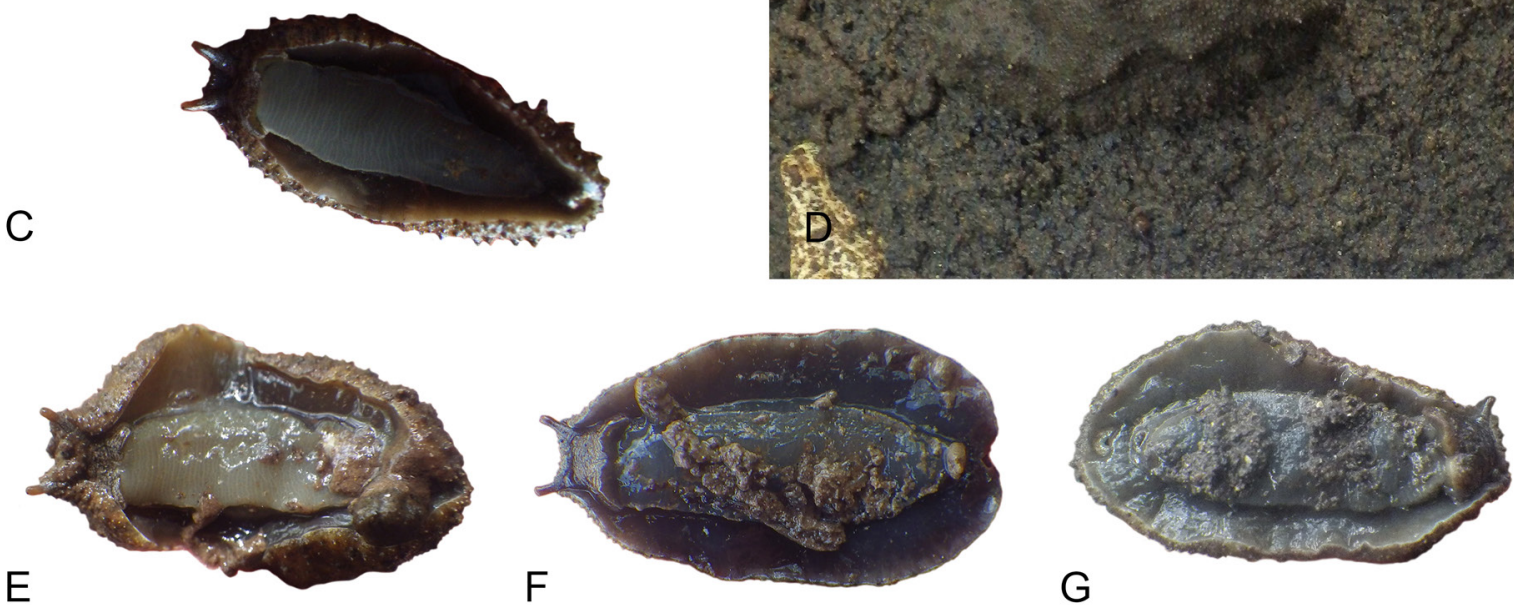

Fig. 46. Paromoionchis goslineri gen. et sp. nov. unit \#2, live animals. A. Dorsal view, $33 \mathrm{~mm}$ long [3120], Indonesia, Bali (UMIZ 00156). B. Dorsal view, $32 \mathrm{~mm}$ long [5073], Indonesia, Halmahera (UMIZ 00158). C. Dorsal and ventral views, $18 \mathrm{~mm}$ long [2241], Indonesia, Sulawesi (UMIZ 00153). D. Dorsal view, $24 \mathrm{~mm}$ long [3079], Indonesia, Bali (UMIZ 00155). E. Ventral view, $26 \mathrm{~mm}$ long [5072], Indonesia, Halmahera (UMIZ 00158). F. Ventral view, $16 \mathrm{~mm}$ long [5891], Indonesia, Timor (UMIZ 00157) G. Ventral view, 26 mm long [3066], Indonesia, Bali (UMIZ 00154). 
gen. et sp. nov. (no accessory penial gland, thin penis with no hooks) is very distinctive and can be used for a fully reliable identification. The only other species of Paromoionchis gen. nov. without an accessory penial gland, $P$. penangensis gen. et sp. nov., differs greatly from $P$. goslineri gen. et sp. nov. anatomically because its penis is very large. Units $\# 1$ and $\# 2$ of $P$. goslineri gen. et sp. nov. differ slightly with respect to the penial retractor: it is short and thin, inserting near the nervous system, or even vestigial in unit \#1, while it is as long as the penial sheath, inserting near the heart in unit \#2. However, given that only four specimens could be dissected in unit \#1, it is very possible that intermediates may be found in the future, especially considering that units \#1 and \#2 are widely distant geographically.

\section{Distribution (Fig. 6)}

Philippines (unit \#1): Luzon (type locality). Indonesia (unit \#2): Ambon, Bali, Halmahera, Sulawesi and Timor.

\section{Habitat (Fig. 51)}

Paromoionchis goslineri gen. et sp. nov. unit \#1 is found on mud, in Avicennia forests near the shore and is rare (only four specimens are known from two stations). Unit \#2 is found on soft and hard mud, in mangroves or in open areas near mangroves and is rare (except in Bali, where several specimens were found at a few stations).
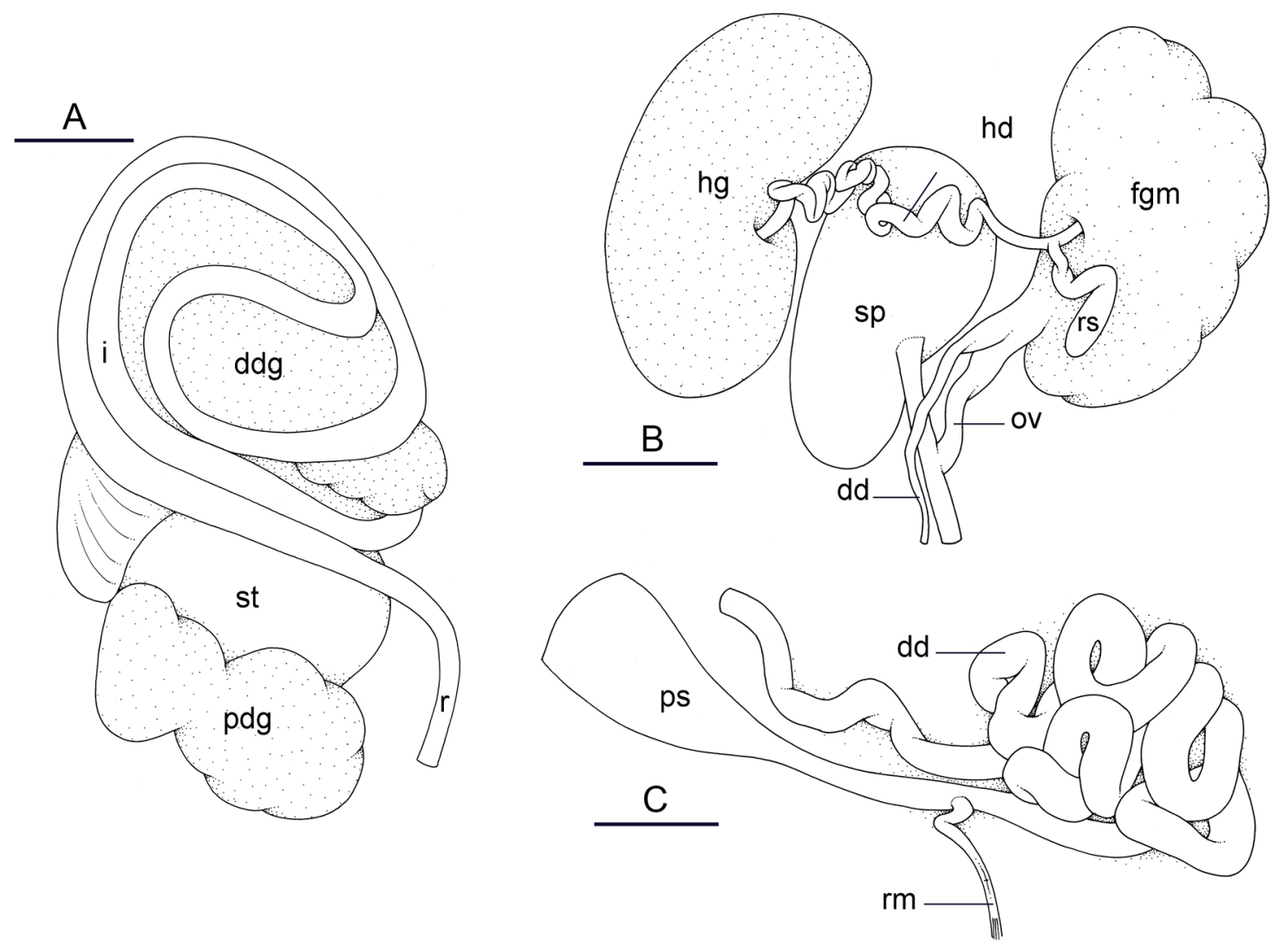

Fig. 47. Paromoionchis goslineri gen. et sp. nov. unit \#1, holotype, Philippines, Luzon [3233] (PNM 041271). A. Digestive system. B. Posterior hermaphroditic (female) reproductive system. C. Male copulatory organs. Abbreviations: $\mathrm{dd}=\mathrm{deferent} \mathrm{duct}$; $\mathrm{ddg}=\mathrm{dorsal}$ lobe of digestive gland; fgm = female gland mass; hd $=$ hermaphroditic duct; $\mathrm{hg}=$ hermaphroditic gland; $\mathrm{i}=$ intestine; ov $=$ oviduct; $\mathrm{pdg}=$ posterior lobe of digestive gland; $\mathrm{ps}=$ penial sheath; $\mathrm{r}=$ rectum; $\mathrm{rm}=$ retractor muscle; $\mathrm{rs}=$ receptaculum seminis; $\mathrm{sp}=$ spermatheca; $\mathrm{st}=$ stomach. Scales: $\mathrm{A}-\mathrm{B}=2 \mathrm{~mm} ; \mathrm{C}=1 \mathrm{~mm}$. 


\section{Discussion}

\section{Nomenclature}

Five species names are regarded as names of doubtful application (nomina dubia) for a variety of reasons (the type locality is too vague, the original description is not informative enough, the type material is destroyed or lost): Onchidium griseum Plate, 1893, O. lixii Labbé, 1934, O. palaense Semper, 1880, O. papuanum Semper, 1880 and O. straelenii Labbé, 1934.

Onchidium palaense Semper, 1880 could belong to Paromoionchis gen. nov., but its application is doubtful and it is regarded as a nomen dubium. The publication date for $O$. palaense is 1880 because it is the year in which Semper's plate 23 was published. ICZN Article 12.2.7 applies and Semper's fig. 8 on plate 23 is an indication accompanying the name. The written description of $O$. palaense was published two years later (Semper 1882: 275-276, pl. 21, fig. 8). Its type locality is Aibukit, Palau Islands, in the western Pacific. However, the type material (two syntypes) could not be located, which makes it impossible to determine some key characters not described by Semper. Semper indicated the absence of a rectal gland and of an accessory penial gland, but $O$. palaense cannot be reliably assigned to a genus without information on its digestive system type (type I or type II), because slugs without a rectal gland or an accessory penial gland are found in more than one clade. The position of the male aperture (between the two eye tentacles) seems to suggest that $O$. palaense could belong to Paromoionchis gen. nov. However, the position of the male aperture cannot be verified here and Semper did not always describe it accurately (see our remarks on P. daemelii and P. tumidus above). That the
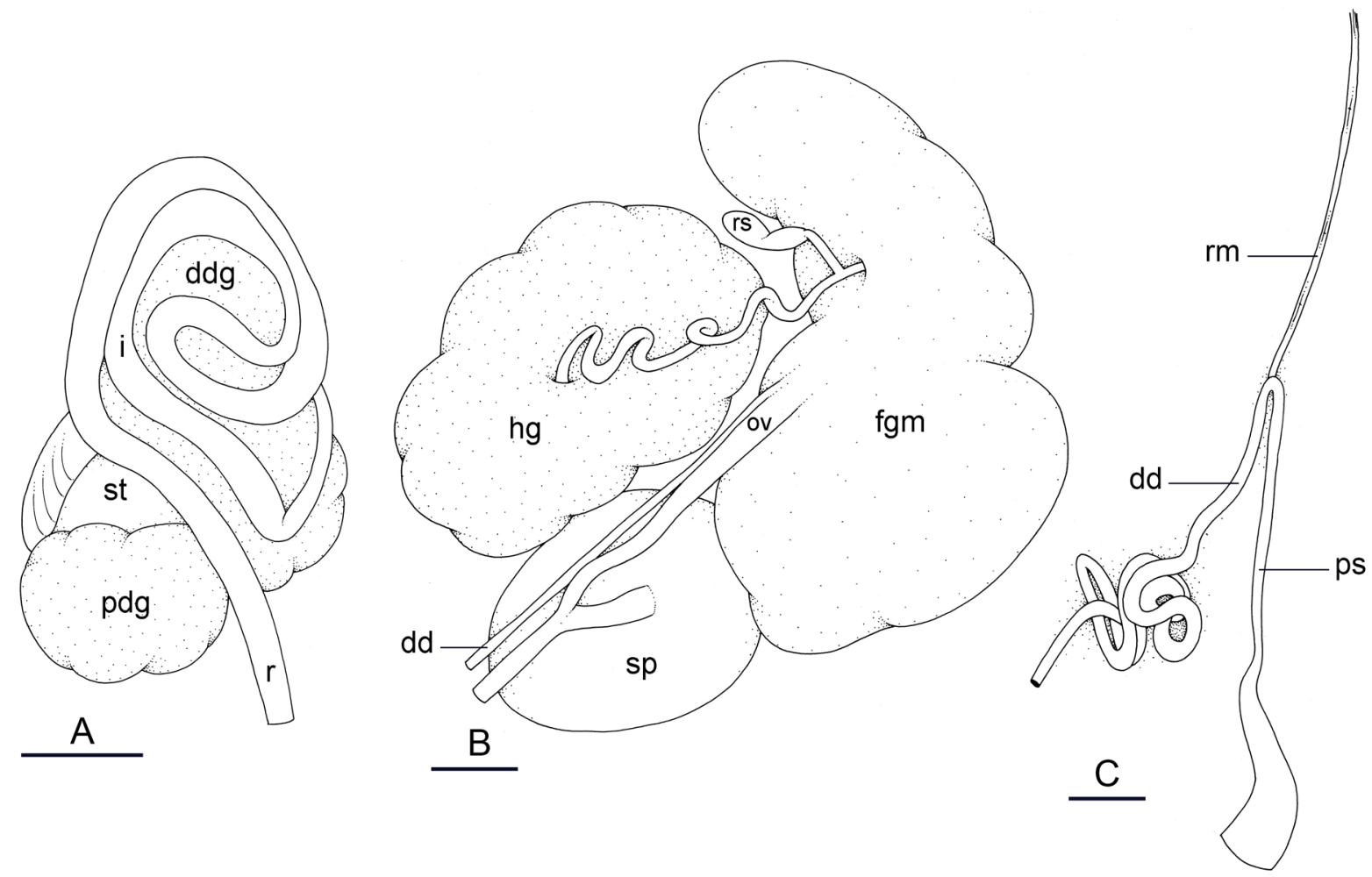

Fig. 48. Paromoionchis goslineri gen. et sp. nov. unit \#2, Indonesia, Sulawesi [2241] (UMIZ 00153). A. Digestive system. B. Posterior hermaphroditic (female) reproductive system. C. Male copulatory organs. Abbreviations: $\mathrm{dd}=$ deferent duct; $\mathrm{ddg}=$ dorsal lobe of digestive gland; fgm $=$ female gland mass; hd = hermaphroditic duct; $\mathrm{hg}=$ hermaphroditic gland; $\mathrm{i}=$ intestine; ov = oviduct; $\mathrm{pdg}=$ posterior lobe of digestive gland; $p s=$ penial sheath; $r=$ rectum; $r m=$ retractor muscle; $r s=$ receptaculum seminis; $\mathrm{sp}=$ spermatheca; $\mathrm{st}=$ stomach. Scales: $\mathrm{A}=2 \mathrm{~mm} ; \mathrm{B}-\mathrm{C}=1 \mathrm{~mm}$. 
original description of Onchidium palaense by Semper does not provide enough information to decide on a generic placement is demonstrated by the fact that Hoffmann (1928: 82) thought that $O$. palaense and $O$. gracile Stantschinsky, 1907 were synonyms because of a "striking agreement" in their anatomy. However, $O$. gracile belongs to a different genus characterized by a digestive system of type I and is now known as Wallaconchis gracilis (see Goulding et al. 2018c). When the type material is lost and the original description is incomplete, a name can apply to basically anything! Therefore, it is more reasonable to regard $O$. palaense as a nomen dubium. Even if a distinct species of Paromoionchis gen. nov. were to be found one day in Palau, there is no guarantee that it would actually belong to Semper's species. Finally, Plate (1893: 180) reported O. palaense from Ambon based on a single specimen (with intestinal loops of type I). However, Plate acknowledged that the identification of that specimen was uncertain.

Onchidium papuanum Semper, 1880 could belong to Paromoionchis gen. nov., but is regarded as a nomen dubium because the type locality is too vague and because the type material is lost. Since Semper's plate 23 was published in 1880, ICZN Article 12.2.7 applies and Semper's fig. 9 on plate 23 is an indication accompanying the name. The written description of $O$. papuanum was published two years later (Semper 1882: 276-277, pl. 21, fig. 17). The type locality ("New Guinea") is too vague because it could be anywhere on the shore of the entire island of New Guinea (i.e., Indonesia and Papua New Guinea). Also, the type material could not be located and is likely lost. As a result, important characters cannot be checked, such as the type of the digestive system, which Semper does not mention. Slugs with no rectal gland and no accessory penial gland are found in more than one clade, so O. papuanum may or may not belong to Paromoionchis gen. nov. Even if O. papuanum was assumed to belong to
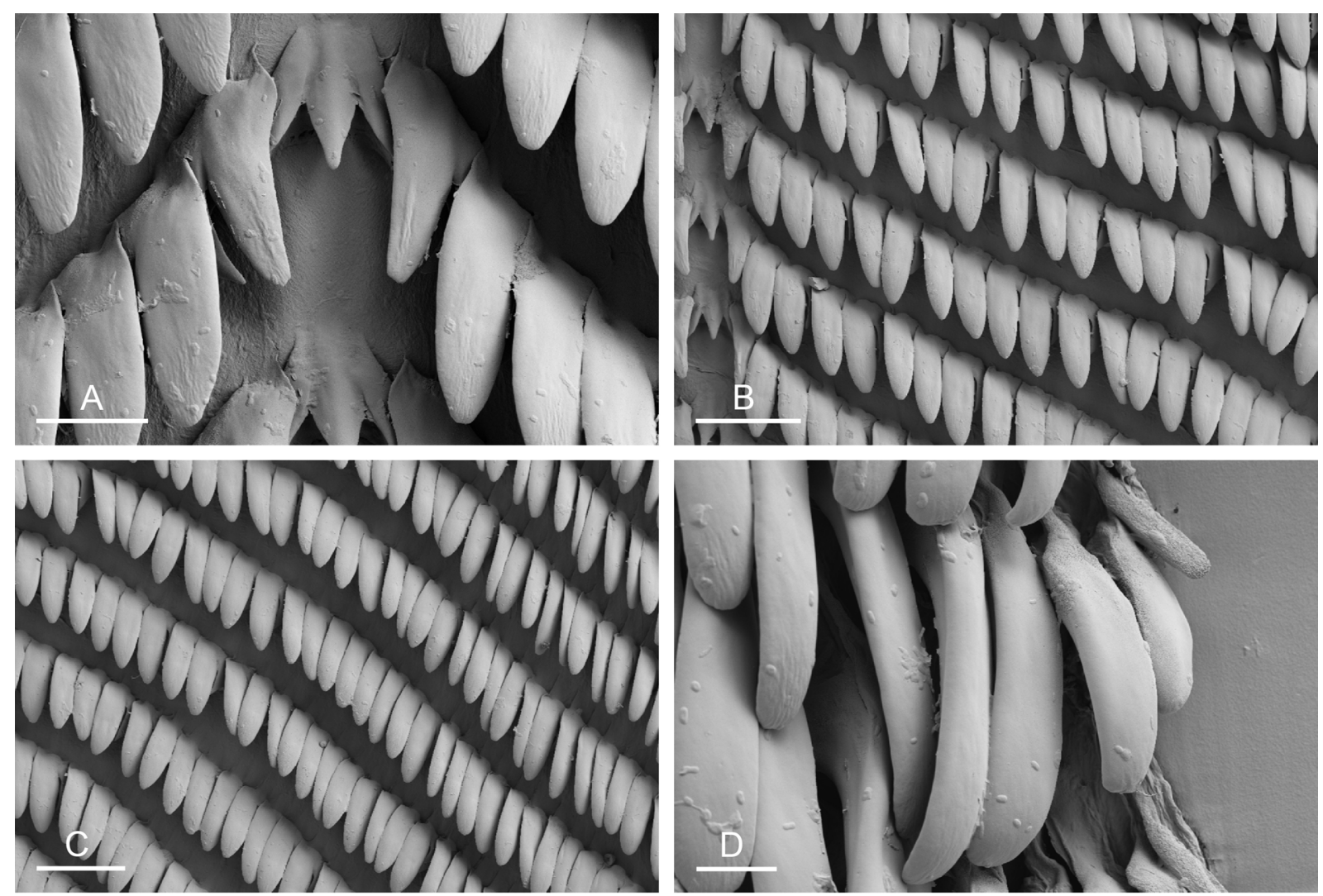

Fig. 49. Paromoionchis goslineri gen. et sp. nov. unit \#1, radula, Philippines, Luzon [6049] (PNM 041272). A. Rachidian and innermost lateral teeth. B. Lateral teeth with rachidian teeth. C. Lateral teeth. D. Outermost lateral teeth. Scales: A $=20 \mu \mathrm{m}$; $B-C=50 \mu \mathrm{m} ; \mathrm{D}=10 \mu \mathrm{m}$. 
Paromoionchis gen. nov., its male anatomy (penis with a large spherical vestibule) does not match that of any of the species described here. Previous authors have struggled with this species. Tapparone-Canefri (1883: 215) transferred O. papuanum to Peronia, as Peronia papuana, with no justification. Bretnall (1919: 317) commented on the anatomy of $O$. papuanum, which he regarded as valid, but without examining any new material. Based on two non-type specimens from New Guinea, Labbé (1934a: 230) transferred $O$. papuanum to his genus Paraoncidium (which is actually a junior synonym of Onchidina Semper, 1882), but acknowledged that the identification of those two specimens as Paraoncidium papuanum was only probable.

Onchidium griseum Plate, 1893 belongs to Paromoionchis gen. nov., but is regarded as a nomen dubium because the type locality is uncertain. In the original description (Plate 1893: 179), the specimens are said to be "of unknown origin, probably from one of the Polynesian islands." Also, no locality is indicated on the labels of the four syntypes (ZMB 45657). However, given its anatomy (digestive system of type II, no rectal gland, presence of an accessory penial gland and a male opening left of the right eye tentacle), we know that $O$. griseum belongs to Paromoionchis gen. nov.

Onchidium straelenii Labbé, 1934 may or may not belong to Paromoionchis gen. nov., but is regarded as a nomen dubium. The two syntypes used by Labbé were located (RBINS) and an examination of them revealed that his description is seriously erroneous regarding several important characters. For instance, Labbé (1934b: 76, our translation) described "numerous, small and very ramified gills" on the dorsal notum, which explains why Labbé (1934a) later transferred that species to Scaphis, a genus he created for onchidiids with dorsal gills. However, there are no gills at all on the notum of the two
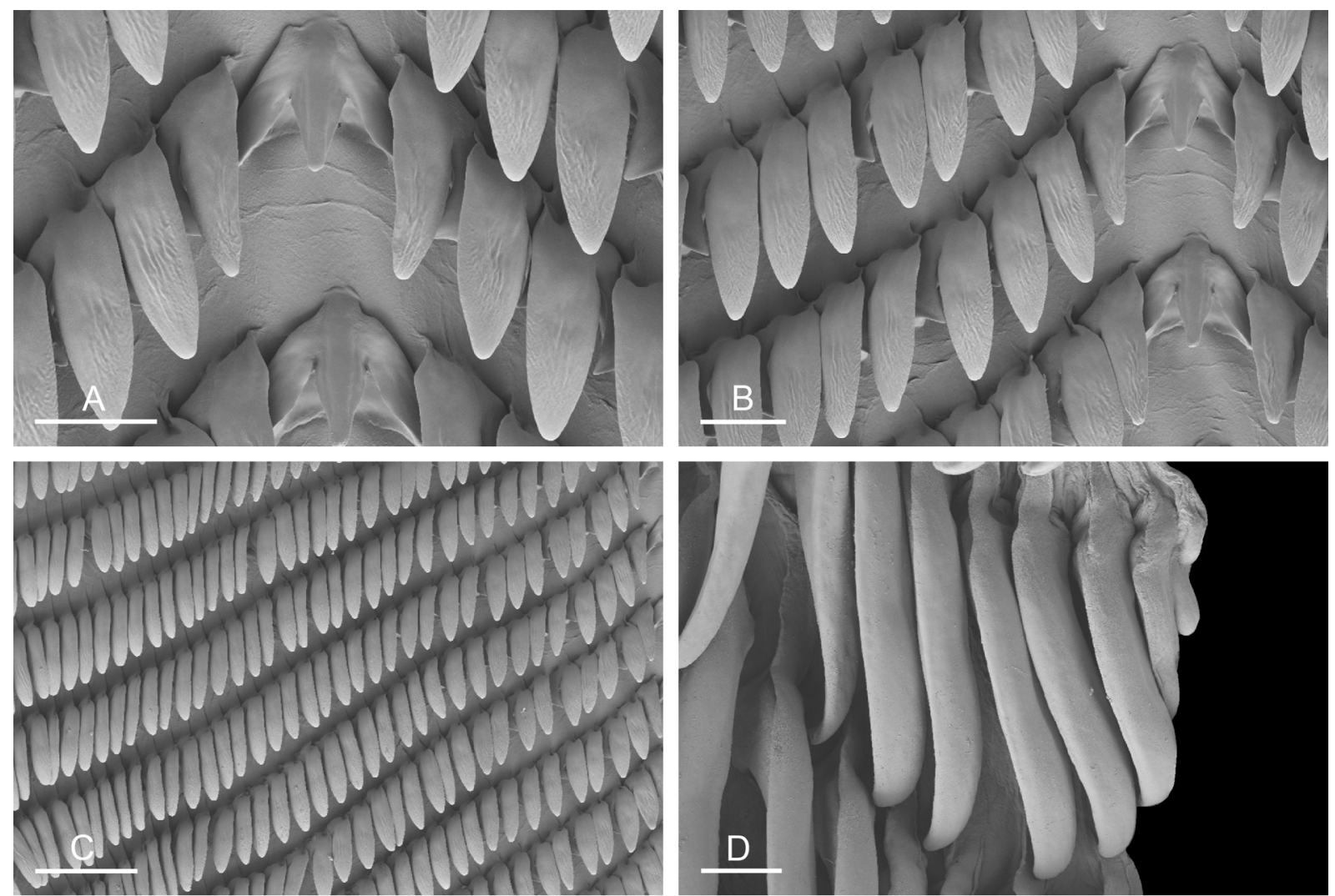

Fig. 50. Paromoionchis goslineri gen. et sp. nov. unit \#2, radula, Indonesia, Bali [3078] (UMIZ 00155). A. Rachidian and innermost lateral teeth. B. Lateral teeth with rachidian teeth. C. Lateral teeth. D. Outermost lateral teeth. Scales: $A-B=20 \mu \mathrm{m} ; C=30 \mu \mathrm{m} ; \mathrm{D}=10 \mu \mathrm{m}$. 

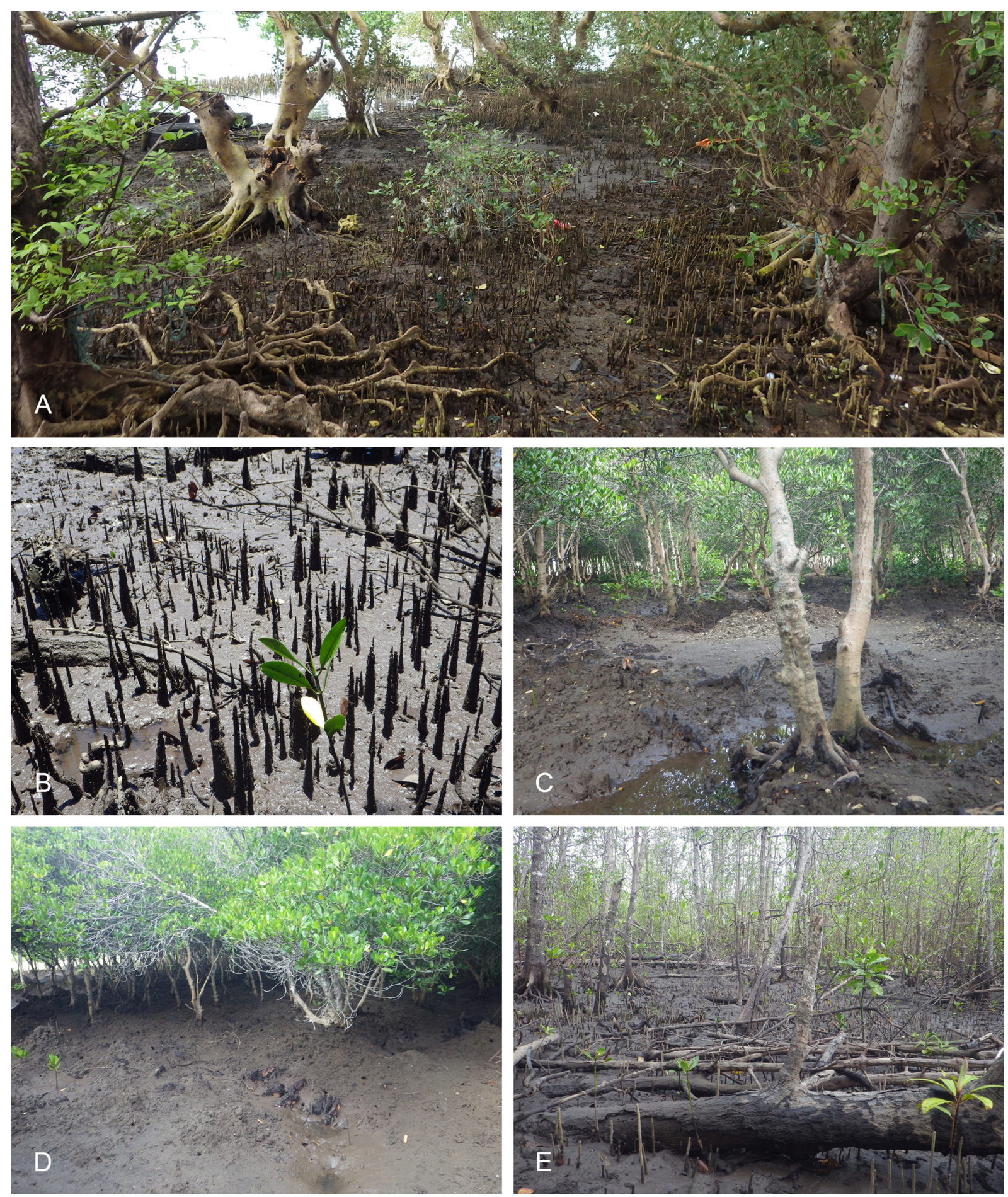

Fig. 51. Paromoionchis goslineri gen. et sp. nov., habitats. A. Philippines, Luzon, impacted mangrove next to a village, narrow band of Avicennia by the shore (station 185, type locality). B. Indonesia, Sulawesi, mostly Rhizophora, with sand, small rocks and pieces of wood outside narrow coastal mangrove (station 89). C. Indonesia, Bali, short mangrove shrubs, high intertidal, muddy area with pools (station 155). D. Indonesia, Bali, short mangrove shrubs high in intertidal, muddy area with pools (station 156). E. Indonesia, Halmahera, Rhizophora trees in open mangrove with sandy and muddy areas (station 219). 
syntypes of $O$. straelenii. Furthermore, Labbé described a digestive system of type I, but it is clearly of type II. Sadly, these kinds of mistakes are not unusual in Labbé's work. Consequently, these mistakes make it impossible to trust any of the other features he described for the anatomy of the male apparatus (accessory penial gland present and penis with hooks), which cannot be checked because the male parts are missing in both syntypes. The characters of the syntypes (digestive system of type II, male aperture clearly on the left of the right eye tentacle, no rectal gland) suggest that $O$. straelenii belongs to Paromoionchis gen. nov. However, its application remains doubtful, although it is clear that $O$. straelenii does not belong to Peronia, the clade including all onchidiids with dorsal gills.

Onchidium lixii Labbé, 1934 likely belongs to Paromoionchis gen. nov. but it is regarded as a nomen dubium because the original description is confusing and the type locality ("New Guinea") is too vague. The four syntypes used by Labbé were located (MNHN Malacologie 22955). An examination of them revealed that the original description is based on specimens that belong to two species. Three syntypes were fully dissected by Labbé. In two of these syntypes (both $27 / 22 \mathrm{~mm}$ long), the male parts are completely missing, so we cannot verify the presence of an accessory penial gland (present according to Labbé's original description). The digestive system of one of these syntype is of type II (as described by Labbé); the digestive type of the second syntype could not be checked because it was destroyed by Labbé. In the third syntype dissected by Labbé $(25 / 20 \mathrm{~mm})$, the male parts are still inside the specimen, there is no accessory penial gland, and it does not seem that this gland was removed by Labbé. Thus, the presence of an accessory penial gland cannot be confirmed in that syntype. Its digestive system is of type II. Finally, a fourth syntype was left almost intact by Labbé, who only cut a small square of the dorsal notum but did not open it (and so none of its internal organs were touched by Labbé). Some characters of that fourth syntype are consistent with Labbé's original description: dorsum with no gills, digestive system of type II, and no rectal gland. However, an accessory penial gland is clearly absent. All four syntypes must belong to some species of Paromoionchis gen. nov., because they share a unique combination of two traits which characterizes this genus (a digestive system of type II and no rectal gland). However, those four syntypes may not all belong to the same species. If Labbé did really see an accessory penial gland in two (or three) syntypes, then they belong to a different species than the fourth syntype (in which the accessory penial gland is absent). If Labbé made a mistake and described an accessory penial gland that did not exist, then all those syntypes could belong to the same species. The fact that Labbé actually illustrated an accessory penial gland and its spine (Labbé 1934a: fig. 67) is not a guarantee that he actually saw it. We know for a fact that he illustrated various structures that he could not have seen. For instance, Labbé (1934a: 206) erroneously described dorsal gills and an accessory penial gland in the syntypes of Onchidium ater. Because of the uncertainty regarding the accessory penial gland, the application of the name O. lixii remains doubtful. One could designate the syntype which Labbé did not open as a lectotype. However, this would not help with the fact that the type locality ("New Guinea") is too vague; the syntypes could have been collected anywhere in West Papua (Indonesia), Papua (Indonesia) or mainland Papua New Guinea. So, in conclusion, Onchidium lixii is regarded as a nomen dubium.

\section{Diversity}

The analysis of three distinct data sets (comparative anatomy, mitochondrial DNA sequences and nuclear DNA sequences) provides invaluable insight on species boundaries. The mitochondrial units within P. tumidus, $P$. boholensis gen. et sp. nov. and P. goslineri gen. et sp. nov. are found to be reciprocally monophyletic and are separated by a wide gap in genetic divergences using mitochondrial DNA sequences (Figs 1-2, 5). However, they are not regarded as species for two main reasons: 1) nuclear markers suggest that there still is gene flow between mitochondrial units (because units are not recovered as reciprocally monophyletic in analyses based on nuclear markers) and 2) mitochondrial units are not distinct anatomically, especially for the male copulatory apparatus, which is essential for maintaining or preventing interbreeding. Naturally, one cannot completely exclude the hypothesis that 
nuclear markers are not variable enough to distinguish species and that the least-inclusive units based on mitochondrial DNA sequences (especially COI) should be regarded as species. However, it seems easier to interpret those mitochondrial units as divergent haplotypes that have been maintained due to maternal inheritance. Studies on land snails and slugs (Stylommatophora), to which onchidiids are closely related, have shown that very old (20 million years) distinct haplotypes can co-occur within a single population (e.g., Thomaz et al. 1996; Pinceel et al. 2005). Because of the multiple changes in sea levels in South-East Asia, especially during the glacial-interglacial cycles in the Quaternary (e.g., Bowen et al. 2016), there were many opportunities for small populations to be isolated in refuges at regular periods. Furthermore, the results from nuclear sequences suggest that isolation has not always led to speciation, because gene flow is still happening between individuals representing old, distinct mitochondrial haplotypes. The present study shows the critical importance of using nuclear DNA sequences in addition to mitochondrial DNA sequences because, had we used mitochondrial DNA sequences alone, we could have erroneously postulated the existence of nine species of Paromoionchis gen. nov., including several cryptic species.

Prior to the present study, only two species of Paromoionchis gen. nov. were known: P. tumidus, for which there are three junior synonyms, and $P$. daemelii, described once. These two species were originally classified in Onchidium, traditionally used by default for most Indo-West Pacific onchidiids. However, Onchidium refers to a small clade of only three species (Dayrat et al. 2016) from which species of Paromoionchis gen. nov. highly differ anatomically (for example, the latter slugs lack a rectal gland). Also, molecular phylogenetics strongly supports the monophyly of Paromoionchis gen. nov., with respect to all other onchidiids. Both P. tumidus and P. daemelii were known exclusively from the types, showing that it has remained very difficult for authors to re-identify them. Here, dozens of new records are provided for P. tumidus, from the Andaman Islands (Bay of Bengal) all the way to the subtropical waters of Japan $\left(33^{\circ} \mathrm{N}\right)$ and southeastern Australia $\left(33^{\circ} \mathrm{S}\right)$. It is not surprising that P. tumidus was described four different times, because it is a very common species across its geographic distribution. New records are provided for $P$. daemelii (in Queensland) and it is shown to be endemic to eastern Australia.

The three other species of Paromoionchis gen. nov. are new to science. One might wonder how those species of large slugs have remained unnoticed for so long. However, it is not so surprising considering that the mangroves of South-East Asia have been very poorly explored and that these new species tend to be rare and found at only a few of the numerous stations that were visited (more than 260 stations across the Indo-West Pacific).

Species of Paromoionchis gen. nov. all live on mud, in or near mangroves. They are mostly found directly on the mud surface, which is their preferred habitat, but they can also be found on old logs covered with mud. Most species live on both soft mud (saturated in water) and hard mud (not saturated in water). Occasionally, some species (P. tumidus, P. daemelii, P. boholensis gen. et sp. nov.) can also be found on muddy sand (sand that is slightly muddy, usually with a few Avicennia trees). It is interesting to notice that some onchidiid genera seem to be more or less specialized to a particular habitat: for instance, Peronina is specialized to very soft mud, Melayonchis to tree roots and trunks, Platevindex to tree trunks and old logs covered with mud and Peronia to the rocky intertidal. We have never found Paromoionchis gen. nov. in the rocky intertidal and only very occasionally have we found it on old logs (mostly P. tumidus).

Each onchidiid genus is characterized by a distinct combination of anatomical characters. Thus, all onchidiids can easily be identified at the generic level as long as some key anatomical characters are known (presence or absence of dorsal gills, type of intestinal loops, position of the male opening, absence or presence of rectal gland, absence or presence of an accessory penial gland). Members of Paromoionchis gen. nov. are characterized by lacking dorsal gills and a rectal gland, and by having a male opening below and to the left of the right eye tentacle and intestinal loops of type II. Furthermore, 
the monophyly of each genus is strongly supported by molecular data. Within each onchidiid genus, however, it is common for species of to be indistinguishable externally, although in most cases species differ internally, especially for the male copulatory apparatus. Species of Paromoionchis gen. nov. are cryptic externally due to their similar color patterns and to high individual variation, but they are distinct internally (Table 3).

\section{Identification key}

A key is provided here to help identify the five species of Paromoionchis gen. nov. Because species cannot be distinguished externally, the key is based on internal characters of reproductively mature specimens.

1. Accessory penial gland absent .2

- Accessory penial gland present 3

2. Penis large, within large penial sheath .....P. penangensis gen. et sp. nov. (W India to Malacca Strait) - Penis thin, within thin penial sheath ........P. goslineri gen. et sp. nov. (Indonesia and Philippines)

3. Penial retractor muscle reaches heart; thin penis with hooks ....P. tumidus (Semper, 1880) (Andaman Islands to subtropical waters of SE Australia and S Japan)

- Penial retractor muscle very short, vestigial, or absent; thin penis with no hooks .4

4. Accessory penial gland spine $<1.8 \mathrm{~mm}$ in length

P. boholensis gen. et sp. nov. (Indonesia and Philippines)

- Accessory penial gland spine $>2.5 \mathrm{~mm}$ in length P. daemelii gen. et sp. nov. (SE Australia)

\section{Acknowledgments}

We thank associate editor Kurt Jordaens, reviewer Eike Neubert and an anonymous reviewer for helpful suggestions which improved this manuscript. We are grateful to all the people who helped us with field work in various ways, by hosting us at their institutions, helping with logistics or accompanying us in the field. Our study would have been impossible without their generous help and efforts: Vishal Bhave, Sudhir Sapre and C.R. Sreeraj in India; Teddy Chua in Brunei Darussalam; Neil L. Bruce in Queensland; Rosemary Golding and Winston Ponder in New South Wales; Richard Willan in Northern Territory; Vivian Ang, Don Dumale and Marivene Manuel in the Philippines; Ngô Xuân Quảng in Vietnam. We thank Philippe Bouchet (MNHN) for allowing us to study some material collected during an expedition he led to Papua New Guinea. Accessing mangrove sites would have been impossible without help from local fishermen and villagers. We are grateful to Rahul C. Salunkhe and Yogesh Shouche (BNHS and National Center for Cell Science, Pune) for their help with the DNA sequencing of specimens from India. We are also grateful to Barbara Buge and Nicolas Puillandre for handling the DNA barcoding of specimens at MNHN. We wish to warmly thank all the collection managers of various institutions for accepting to host our material in their collections or sending us specimens on loan: AM, BDMNH, BNHS, ITBZC, MNHN, MTQ, NHM, NHMD, NSMT, NTM, PNM, RBINS, SMF, UMIZ, USMMC, ZMB and ZMH. Specimens were collected following local regulations, as overseen by Shau Hwai Tan (Malaysia), Deepak Apte (India), Marivene Manuel (Philippines) and Munawar Khalil (Indonesia). Collecting in Brunei, New South Wales, Queensland and Northern Territory was done with permits from local institutions. We thank the Ministry of Research, Technology and Higher Education, Republic of Indonesia (Ristek-Dikti), which issued a research permit to Benoît Dayrat (Ristek \#134/SIP/FRP/E5/ Dit.KI/VI/2017). We also wish to thank the Universitas Malikussaleh (UMIZ) for being our homebase institution in Indonesia. The material from Papua New Guinea was collected during a MNHN-PNI-IRD Our Planet Reviewed expedition (PI: Philippe Bouchet), funded by the Stavros Niarchos Foundation, Total Foundation, Prince Albert II of Monaco Foundation, Fondation EDF, Entrepose Contracting and Fonds Pacifique, and operated under permits delivered by the Papua New Guinea Department 
DAYRAT B. et al., A new genus of mangrove onchidiid slugs

of Environment and Conservation. This work was supported by the Eberly College of Science at the Pennsylvania State University and by a REVSYS (Revisionary Syntheses in Systematics) award from the US National Science Foundation (DEB 1419394).

\section{References}

Boettger C.R. 1923. Die Landschneckenfauna der Aru- und der Kei-Inseln. Abhandlungen herausgegeben von der Senckenbergischen Naturforschenden Gesellschaft 35: 353-418.

Available from https://biodiversitylibrary.org/page/48257011 [accessed 22 Dec. 2018].

Bowen B.W., Gaither M.R., DiBattista J.D., Iacchei M., Andrews K.R., Grant W.S., Toonen R.J. \& Briggs J.C. 2016. Comparative phylogeography of the ocean planet. Proceedings of the National Academy of Sciences 113: 7962-7969. https://doi.org/10.1073/pnas.1602404113

Bretnall W. 1919. Onchidiidae from Australia and the South-Western Pacific Islands. Records of the Australian Museum 12: 303-328. https://doi.org/10.3853/j.0067-1975.12.1919.888

Britton K.M. 1984. The Onchidiacea (Gastropoda, Pulmonata) of Hong Kong with a worldwide review of the genera. Journal of Molluscan Studies 50: 179-191.

https://doi.org/10.1093/oxfordjournals.mollus.a065863

Dayrat B. 2005. Towards integrative taxonomy. Biological Journal of the Linnean Society 87: 407-415. https://doi.org/10.1111/j.1095-8312.2005.00503.x

Dayrat B. 2009. Review of the current knowledge of the systematics of Onchidiidae (Mollusca: Gastropoda: Pulmonata) with a checklist of nominal species. Zootaxa 2068: 1-26.

Dayrat B. 2010. Anatomical re-description of the terrestrial onchidiid slug Semperoncis montana (Plate, 1893). Malacologia 52: 1-20. https://doi.org/10.4002/040.052.0101

Dayrat B. \& Goulding T.C. 2017. Systematics of the onchidiid slug Onchidina australis (Mollusca: Gastropoda: Pulmonata). Archiv für Molluskenkunde 146: 121-133.

https://doi.org/10.1127/arch.moll/146/121-133

Dayrat B., Conrad M., Balayan S., White T.R., Albrecht C., Golding R., Gomes S., Harasewych M.G. \& Frias Martins A.M. de. 2011a. Phylogenetic relationships and evolution of pulmonate gastropods (Mollusca): new insights from increased taxon sampling. Molecular Phylogenetics and Evolution 59: 425-437. https://doi.org/10.1016/j.ympev.2011.02.014

Dayrat B., Zimmermann S. \& Raposa M. 2011b. Systematic revision of the Onchidiidae from the tropical Eastern Pacific. Journal of Natural History 45: 939-1003.

https://doi.org/10.1080/00222933.2010.545486

Dayrat B., Goulding T.C., Apte D., Bhave V., Comendador J., Ngô X.Q., Tan S.K. \& Tan S.H. 2016. Integrative taxonomy of the genus Onchidium Buchannan, 1800 (Mollusca, Gastropoda, Pulmonata, Onchidiidae). ZooKeys 636: 1-40. https://doi.org/10.3897/zookeys.636.8879

Dayrat B., Goulding T.C., Apte D., Bhave V. \& Ngô X.Q. 2017. A new genus and four new species of onchidiid slugs from South-East Asia (Mollusca: Gastropoda: Pulmonata: Onchidiidae). Journal of Natural History 51: 1851-1897. https://doi.org/10.1080/00222933.2017.1347297

Folmer O., Black M., Hoeh W., Lutz R. \& Vrijenhoek R. 1994. DNA primers for amplification of mitochondrial cytochrome c oxidase subunit I from diverse metazoan invertebrates. Molecular Marine Biology and Biotechnology 3: 294-299.

Goulding T.C., Khalil M., Tan S.H. \& Dayrat B. 2018a. A new genus and a new species of onchidiid slugs from eastern Indonesia (Gastropoda: Euthyneura: Onchidiidae). Raffles Bulletin of Zoology 66: $337-349$. 
Goulding T.C., Tan S.H., Tan S.K., Apte D., Bhave V., Narayana S., Salunkhe R. \& Dayrat B. 2018b. A revision of Peronina Plate, 1893 (Gastropoda: Euthyneura: Onchidiidae) based on mitochondrial and nuclear DNA sequences, morphology, and natural history. Invertebrate Systematics 32: 803-826. https://doi.org/10.1071/is17094

Goulding T.C., Khalil M., Tan S.H. \& Dayrat B. 2018c. Integrative taxonomy of a new and highly-diverse genus of onchidiid slugs from the Coral Triangle (Gastropoda: Pulmonata: Onchidiidae). ZooKeys 763: 1-111. https://doi.org/10.3897/zookeys.763.21252

Guindon S. \& Gascuel O. 2003. A simple, fast, and accurate algorithm to estimate large phylogenies by maximum likelihood. Systematic Biology 52: 696-704. https://doi.org/10.1080/10635150390235520

Hassouna N., Mithot B. \& Bachellerie J.P. 1984. The complete nucleotide sequence of mouse 28S rRNA gene. Implications for the process of size increase of the large subunit rRNA in higher eukaryotes. Nucleic Acids Research 12: 3563-3583. https://doi.org/10.1093/nar/12.8.3563

Hoffmann K. 1928. Zur Kenntnis der Oncidiiden. Zoologische Jahrbücher, Jena 55: 29-118.

Johnson R.I. 1969. Semper's Reisen im Archipel der Philippinen, wissenschaftliche Resultate, 18671916. A complete collation. Journal of the Society for the Bibliography of Natural History 5: 144-147. https://doi.org/10.3366/jsbnh.1969.5.2.144

Kenny R. \& Smith A. 1987. Distribution of Onchidium damelii Semper (Gastropoda, Onchidiidae). Pacific Science 41: 21-30.

Kenny R. \& Smith A. 1988. Emergence behaviour of Onchidium damelii Semper, 1882 (Gastropoda, Onchidiidae). Journal of the Malacological Society of Australia 9: 19-20.

https://doi.org/10.1080/00852988.1988.10673996

Labbé A. 1934a. Les Silicodermés (Labbé) du Muséum d'Histoire naturelle de Paris. Première partie: Classification, formes nouvelles ou peu connues. Annales de l'Institut océanographique 14: 173-246.

Labbé A. 1934b. Opisthobranches et Silicodermés (Oncidiadés). Résultats scientifiques du Voyage aux Indes orientales néerlandaises 2 (14): 3-83.

Lendenfeld R. von. 1886. Preliminary report on the histological structure of the dorsal papillae of certain species of Onchidium. Proceedings of the Linnean Society of New South Wales 10: 730-732.

https://doi.org/10.5962/bhl.part.17961

Milne I., Wright F., Rowe G., Marshal D.F., Husmeier D. \& McGuire G. 2004. TOPALi: Software for automatic identification of recombinant sequences within DNA multiple alignments. Bioinformatics 20: 1806-1807. https://doi.org/10.1093/bioinformatics/bth155

Palumbi S.R. 1996. Nucleic acid II: The polymerase chain reaction. In: Hillis D., Moritz C. \& Mable B. (eds) Molecular Systematics. Second edition: 205-247. Sinauer Press, Sunderland, MA.

Pinceel J., Jordaens K. \& Backeljau T. 2005. Extreme mtDNA divergences in a terrestrial slug (Gastropoda, Pulmonata, Arionidae): accelerated evolution, allopatric divergence and secondary contact. Journal of Evolutionary Biology 18: 1264-1280. https://doi.org/10.1111/j.1420-9101.2005.00932.x

Plate L. von. 1893. Studien über opisthopneumone Lungenschnecken. II. Die Oncidiiden. Zoologische Jahrbücher, Anatomie 7: 93-234. Available from https://biodiversitylibrary.org/page/11175213 [accessed 22 Dec. 2018].

Ronquist F. \& Huelsenbeck J.P. 2003. MrBayes 3: Bayesian phylogenetic inference under mixed models. Bioinformatics 19: 1572-1574. https://doi.org/10.1093/bioinformatics/btg180

Semper C. 1880-1885. Dritte Familie, Onchidiidae. In: Semper C. (ed.) Reisen im Archipel der Philippinen. Zweiter Theil. Wissenschaftliche Resultate. Dritter Band. Landmollusken: 251-264 [1880], 
DAYRAT B. et al., A new genus of mangrove onchidiid slugs

265-290 [1882], pl. 19-20, 22-23 [1880], pl. 21 [1882], pl. 24-27 [1885]. C.W. Kreidel, Wiesbaden. Available from https://biodiversitylibrary.org/page/32630046 [accessed 22 Dec. 2018].

Simroth H. 1918. Über einige Nacktschnecken vom Malayischen Archipel von Lombok an ostwärts bis zu den Gesellschafts-Inseln. Abhandlungen herausgegeben von der Senckenbergischen Naturforschenden Gesellschaft 35: 261-302. Available from https://biodiversitylibrary.org/page/48256899 [accessed 22 Dec. 2018].

Sun B., Chen C., Shen H., Zhang K., Zhou N. \& Qian J. 2014. Species diversity of Onchidiidae (Eupulmonata: Heterobranchia) on the mainland of China based on molecular data. Molluscan Research 34: 62-70. https://doi.org/10.1080/13235818.2013.868860

Swofford D.L. 2002. PAUP: Phylogenetic Analysis Using Parsimony, Version 4.0b10. Sinauer, Sunderland, MA.

Tamura K., Strecher G., Peterson D., Filipski A. \& Kumar S. 2013. MEGA6: Molecular Evolutionary Genetics Analysis version 6.0. Molecular Biology and Evolution 30: 2725-2729.

https://doi.org/10.1093/molbev/mst197

Tapparone-Canefri C. 1883. Fauna malacologica delle Nuova Guinea e delle isole adiacenti. Annali del Museo Civico di Storia Naturale di Genova 19: 1-313.

Available from https://biodiversitylibrary.org/page/10812600 [accessed 22 Dec. 2018].

Tenison-Woods J.E. 1888. On the anatomy and life history of Mollusca peculiar to Australia. Journal and Proceedings of the Royal Society of New South Wales 22: 106-187.

Available from https://biodiversitylibrary.org/page/41841920 [accessed 22 Dec. 2018].

Thomaz D., Guiller A. \& Clarke B. 1996. Extreme divergence of mitochondrial DNA within species of pulmonate land snails. Proceedings of the Royal Society B 263: 363-368.

https://doi.org/10.1098/rspb.1996.0056

Vonnemann V., Schrödl M., Klussmann-Kolb A. \& Wägele H. 2005. Reconstruction of the phylogeny of the Opisthobranchia (Mollusca: Gastropoda) by means of 18S and 28S rRNA gene sequences. Journal of Molluscan Studies 71: 113-125. https://doi.org/10.1093/mollus/eyi014

Wade C.M. \& Mordan P.B. 2000. Evolution within the gastropod molluscs; using the ribosomal RNA gene-cluster as an indicator of phylogenetic relationships. Journal of Molluscan Studies 66: 565-570. https://doi.org/10.1093/mollus/66.4.565

Manuscript received: 28 February 2018

Manuscript accepted: 2 December 2018

Published on: 22 February 2019

Topic editor: Rudy Jocqué

Section editor: Kurt Jordaens

Desk editor: Danny Eibye-Jacobsen

Printed versions of all papers are also deposited in the libraries of the institutes that are members of the EJT consortium: Muséum national d'Histoire naturelle, Paris, France; Meise Botanic Garden, Belgium; Royal Museum for Central Africa, Tervuren, Belgium; Royal Belgian Institute of Natural Sciences, Brussels, Belgium; Natural History Museum of Denmark, Copenhagen, Denmark; Naturalis Biodiversity Center, Leiden, the Netherlands; Museo Nacional de Ciencias Naturales-CSIC, Madrid, Spain; Real Jardín Botánico de Madrid CSIC, Spain; Zoological Research Museum Alexander Koenig, Bonn, Germany. 